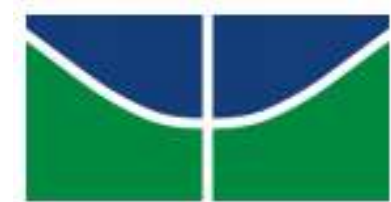

UNIVERSIDADE DE BRASÍLIA

INSTITUTO DE RELAÇÕES INTERNACIONAIS

PROGRAMA DE PÓS-GRADUAÇÃO EM RELAÇÕES INTERNACIONAIS

Robson Cunha Rael

O Novo Banco de Desenvolvimento:

um meio de exercício de poder para o BRICS

Brasília

Dezembro de 2019 


\section{O Novo Banco de Desenvolvimento: um meio de exercício de poder para o BRICS}

Dissertação apresentada ao Programa de PósGraduação em Relações Internacionais do Instituto de Relações Internacionais da Universidade de Brasília como requisito para obtenção de Título de Mestre em Relações Internacionais.

Área de Concentração: Política Internacional e Comparada

Orientadora: Professora Dra. Ana Flávia Granja e Barros

Brasília

Dezembro de 2019 
UNIVERSIDADE DE BRASÍLIA

INSTITUTO DE RELAÇÕES INTERNACIONAIS

Robson Cunha Rael

Dissertação de Mestrado submetida ao Instituto de Relações Internacionais da Universidade de Brasília, como parte dos requisitos necessários para a obtenção do Grau de Mestre em Relações Internacionais, área de concentração Política Internacional e Comparada.

Aprovada em 13 de dezembro de 2019.

Banca Examinadora:

Professora Dra. Ana Flávia Granja e Barros

Instituto de Relações Internacionais, Universidade de Brasília

Orientadora

Professor Dr. Alcides Costa Vaz

Instituto de Relações Internacionais, Universidade de Brasília

Examinador Interno

Professor Dr. Oliver Della Costa Stuenkel

Centro de Relações Internacionais, Fundação Getúlio Vargas/SP

Examinador Externo

Professor Dr. Niels Søndergaard

Instituto de Relações Internacionais, Universidade de Brasília

Suplente 


\section{RESUMO}

O estabelecimento do Novo Banco de Desenvolvimento (NBD) foi um passo importante na institucionalização do BRICS. A pergunta de pesquisa é: Por que o NBD é um meio de exercício de poder? A hipótese é que normas e atos institucionais do Banco constituem um meio de exercício de poder em várias dimensões. O marco teórico, que fundamenta a hipótese, é a literatura sobre o conceito de poder, principalmente a abordagem de David Baldwin (2013), acerca das dimensões do poder. Baldwin identificou cinco dimensões (escopo, domínio, custos, peso e meios). Por meio da soma de abordagens complementares, Nye (2011), Barnett e Duvall (2005), Strange (1994), Wight (2002), Berger (2005), Stuenkel (2017b), entre outros, identificamos mais seis dimensões do poder (método de aplicação de meios, incidência, agência vs. estrutura, grau de dominância, geográfica e grau de transição). Todas as dimensões são explicadas no capítulo teórico. O método é qualitativo e quantitativo, com a análise de dados empíricos e fontes primárias (Acordo Constitutivo, projetos, memorandos de entendimento, relatórios oficiais do Banco, entre outros), para a verificação do grau de presença de cada dimensão do poder na instituição NBD. Como resultados, foram identificadas repercussões do Novo Banco de Desenvolvimento para cada dimensão do poder.

Palavras-chave: Novo Banco de Desenvolvimento (NBD), BRICS, Instituições, Poder, Dimensões do Poder, Meio de Exercício de Poder. 


\begin{abstract}
The establishment of the New Development Bank (NDB) was an important step in the institutionalization of BRICS. The research question is: Why is NDB a means of exercise of power? The hypothesis is that the Bank's rules and institutional acts constitute different means of power exercise in various dimensions. The theoretical framework, which underlies the hypothesis, is the literature on the concept of power, especially David Baldwin's (2013) approach to the dimensions of power. Baldwin identified five dimensions (scope, domain, costs, weight, and means). Through the sum of complementary approaches, Nye (2011), Barnett and Duvall (2005), Strange (1994), Wight (2002), Berger (2005), Stuenkel (2017b), among others, I identified six additional dimensions of power (method of application of means, incidence, agency vs. structure, degree of dominance, geographical and degree of transition). All dimensions are explained in the theoretical chapter. The method is qualitative and quantitative, with the analysis of empirical data and official documents (such as the Constitutional Agreement, projects, memoranda of understanding, Bank reports, among others), to verify the degree of presence of each dimension of power in the NDB. As a result, the repercussions of the New Development Bank were identified for each dimension of power.
\end{abstract}

Keywords: New Development Bank (NDB), BRICS, Institutions, Power, Dimensions of Power, Means of Exercise of Power. 


\section{AGRADECIMENTOS}

Agradeço à minha orientadora, a profissional vocacionada Ana Flávia Granja e Barros, pelas reuniões produtivas e pelos apontamentos de elevado saber. Agradeço aos doutores Oliver Stuenkel, Alcides Costa Vaz e Niels Søndergaard por aceitarem os convites para participação em minha banca examinadora, bem como pelos valiosos comentários acadêmicos. Agradeço aos amigos André Dias, Mariana Salvadori e Sabrina Sabatovicz pelas agradáveis companhias e boas conversas durante à jornada do Mestrado. Agradeço à minha querida noiva Simone Andrea Barcelos Coutinho pela amável companhia e por todo companheirismo, apoio e carinho. Agradeço à minha mãe Maria de Fátima Cunha Rael e ao meu pai Joacil Basílio Rael por todo o enorme apoio de sempre.

Agradeço também à Professora Marisa von Bülow, ao Professor Mathieu Turgeon, ao Professor Pio Penna Filho e à Professora Elisa Ribeiro pelas relevantes contribuições para a minha formação acadêmica. Agradeço aos meus superiores do Tribunal Regional do Trabalho da $10^{\text {a }}$ Região, Eliel Araújo do Nascimento Júnior, Larissa Naves, Dra. Larissa Lizita, Dr. Raul Gualberto e Dra. Margarete Duque, por todo apoio aos meus estudos. 


\section{Lista de Quadros e Tabelas}

\section{Lista de Quadros}

Quadro 1: Instituições

\section{Lista de Tabelas}

Tabela 1: Sedes dos Bancos Multilaterais de Desenvolvimento (BMD)

Tabela 2: Projetos apresentados por países membros do BRICS

Tabela 3: Tempo de Duração dos Projetos

Tabela 4: Exportações de produtos de ferro e aço para a China (em USD)

Tabela 5: Exportações de produtos de maquinários e equipamentos elétricos para a China (em USD)

Tabela 6: $14^{\mathrm{a}}$ Revisão Geral de Quotas para os integrantes do BRICS 


\section{Lista de Siglas}

ADB - Asian Development Bank

ACR - Arranjo de Contingência de Reservas

AfDB - African Development Bank

AGNU - Assembleia Geral das Nações Unidas

AIIB - Asian Infrastructure Investment Bank

ASEAN - Association of Southeast Asian Nations

BADEA - Arab Bank for Economic Development in Africa

BDEAC - Central African States Development Bank

BIMSTEC - Bay of Bengal Initiative for Multi-Sectoral Technical and Economic Cooperation

BM - Banco Mundial

BMD - Banco Multilateral de Desenvolvimento

BNDES - Banco Nacional de Desenvolvimento Econômico e Social

BOAD - West African Development Bank

BRI - Belt and Road Initiative

BRICS - Brasil, Rússia, China, Índia e África do Sul

BSTDB - Black Sea Trade and Development Bank

CABEI - Central American Bank for Economic Integration

CAF - Development Bank of Latin America

CDB - Caribbean Development Bank

CEB - Council of Europe Development Bank

CEI - Comunidade de Estados Independentes

CIJ - Corte Internacional de Justiça

COP21 $-21^{\text {a }}$ Conferências das Partes

CS - Conselho de Segurança das Nações Unidas

DBSA - Development Bank of Southern Africa

EADB - East-African Development Bank

EBRD - European Bank for Reconstruction and Development

EDB - Eurasian Development Bank

EEU - Eurasian Economic Union

EIB - European Investment Bank

ETDB - Economic Cooperation Organization Trade and Development Bank 
FMI - Fundo Monetário Internacional

FONPLATA - Fondo Financiero para el Desarrollo de la Cuenca del Plata

FTA - Free Trade Agreement

G4 - Grupo formado por Alemanha, Brasil, Índia e Japão

G7 - Grupo dos 7

G20 - Grupo dos 20

G77/China - Grupo dos 77 e China

IADB - Inter-American Development Bank

IBRD - International Bank for Reconstruction and Development

IDC - Industrial Development Corporation of South Africa Limited

IIB - International Investment Bank

IsDB - Islamic Development Bank

MDSO - Most Different cases with Similar Outcomes

MERCOSUL - Mercado Comum do Sul

MSDO - Most Similar cases with Different Outcomes

NBD - Novo Banco de Desenvolvimento

NIB - Nordic Investment Bank

ODS - Objetivo de Desenvolvimento Sustentável

OMC - Organização Mundial do Comércio

OPEP - Organização dos Países Exportadores de Pretóleo

OTAN - Organização do Tratado do Atlântico Norte

PIB - Produto Interno Bruto

PNUD - Programa das Nações Unidas para o Desenvolvimento

PROSUL - Foro para o Progresso e a Integração da América do Sul

QCA - Qualitative Comparative Analysis

REDUC - Refinaria Duque de Caxias

REGAP - Refinaria Gabriel Passos

SAARC - South Asian Association for Regional Cooperation

SADC - South African Development Community

SCO - Shanghai Cooperation Organization

UNASUL - União de Nações Sul-Americanas

USD - United States Dollar 


\section{SUMÁRIO}

1. INTRODUÇÃ O.......................................................................................................11

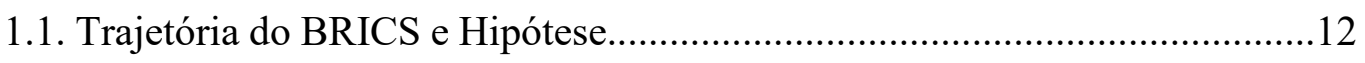

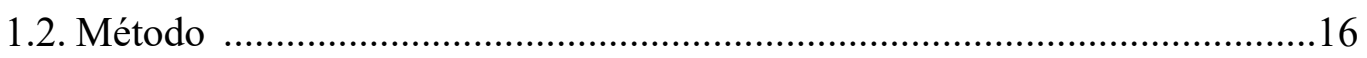

2. UMA SOMA DE ABORDAGENS COMPLEMENTARES SOBRE O

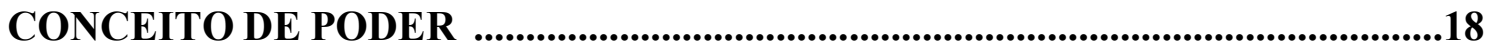

2.1. Dimensão Escopo do Poder...........................................................................19

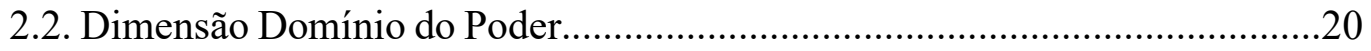

2.3. Dimensão Peso do Poder..................................................................................21

2.4. Dimensão Custos do Poder ...........................................................................21

2.5. Dimensão Meios de Exercício do Poder.........................................................22

2.6. Dimensão Método de Aplicação de Meios (hard power, soft power e smart

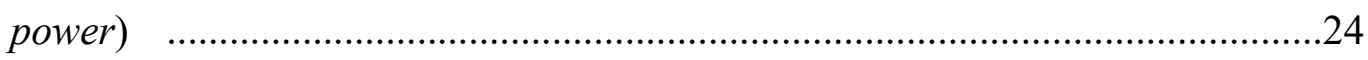

2.7. Dimensão Incidência do Poder (direta ou indireta) ........................................27

2.8. Dimensão Agência vs. Estrutura...................................................................27

2.9. Dimensão Grau de Dominância (power over, power with e power to)..........30

2.10. Dimensão Geográfica (poder terrestre, poder marítimo, poder aéreo e poder

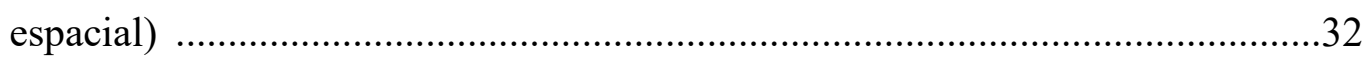

2.11. Dimensão Grau de Transição (power shift e power remain) .......................34

2.12. Fungibilidade ou Conversibilidade...........................................................35

3. APLICAÇÃO DAS DIMENSÕES DO PODER AO NBD - PARTE I..................37

3.1. Dimensão Meios de Exercício de Poder.............................................................37

3.2. Dimensão Escopo do Poder...........................................................................41

3.2.1. Comparação com a Belt and Road Initiative.................................45

3.3. Dimensão Domínio do Poder........................................................................47

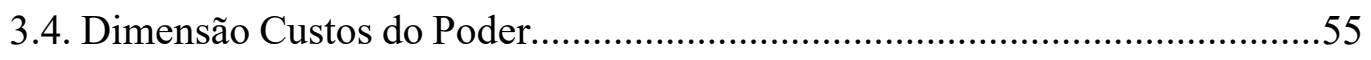

3.5. Dimensão Peso do Poder..........................................................................58

4. APLICAÇÃO DAS DIMENSÕES DO PODER AO NBD - PARTE II.................63

4.1. Dimensão Agência vs. Estrutura..................................................................63

4.2. Dimensão Método de Aplicação de Meios (soft power, hard power e smart power)

4.3. Dimensão Geográfica (poder terrestre, poder marítimo, poder aéreo e poder espacial). 
4.4. Dimensão Incidência do Poder (direta e indireta) .83

4.5. Dimensão Grau de Dominância (power over, power with, power to)...........89

4.6. Dimensão Grau de Transição do Poder (power shift e power remain)..........95

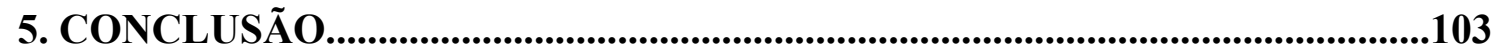

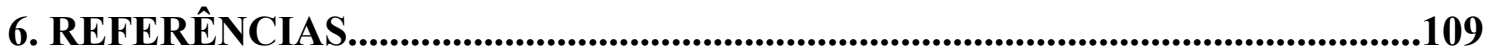




\section{INTRODUÇÃO}

O BRICS é um grupo com características dinâmicas, isto é, que mudam com o tempo. Inicialmente, o grupo era marcado pelo baixo grau de institucionalização, apenas com reuniões de Cúpula e interministeriais, nas quais eram firmadas declarações sobre tópicos diversos da política global e assinados atos diplomáticos, sem um foco específico (memorandos de entendimento, na maioria das vezes). Apesar da continuidade das reuniões, das declarações e dos memorandos de entendimento, em 2014, um acordo firmado entre os membros do BRICS se diferenciou dos demais: aquele da criação do Novo Banco de Desenvolvimento (NBD). Uma instituição foi criada com capital, normas, personalidade jurídica e com potencial de influenciar o cenário internacional.

O Acordo sobre o Novo Banco de Desenvolvimento ${ }^{1}$ foi firmando entre os membros do BRICS em 15 de julho de 2014, na cidade de Fortaleza (Brasil). Conforme o seu artigo 1, o objetivo do Banco é apoiar projetos públicos e privados de infraestrutura e desenvolvimento sustentável, por meio de assistência técnica, garantias, empréstimos, participação acionária e outras formas de ação financeira, bem como por meio da realização de cooperação com organizações internacionais e outras instituições financeiras. $\mathrm{O}$ apoio a projetos e a cooperação visam a geração de crescimento econômico e desenvolvimento, de forma complementar às ações já existentes efetuadas por entidades financeiras multilaterais. O público-alvo são os países do BRICS e outros países em desenvolvimento.

Além do cumprimento de seu objetivo formal, outras razões podem ser identificadas para a criação do NBD. O mundo possui mais de 20 bancos de desenvolvimento (Suchodolski e Demeulemeester, 2018), incluindo alguns que abrangem as áreas geográficas nas quais os membros do BRICS se localizam, como por exemplo: European Bank for Reconstruction and Development ${ }^{2}$, Eurasian Development Bank, Asian Development Bank ${ }^{3}$, African Development Bank ${ }^{4}$, Inter-American Development Bank $^{5}$ e Development Bank of Latin America ${ }^{6}$. A criação de uma instituição financeira por parte de um grupo com potências regionais e globais envolve também, certamente, a

\footnotetext{
${ }^{1}$ BRICS. Acordo sobre o Novo Banco de Desenvolvimento. 2014.

2 https://www.ebrd.com/home Acesso: 17/03/2019 às $17 \mathrm{~h} 26$.

3 https://eabr.org/en/ Acesso: 17/03/2019, às 17h26.

4 https://www.afdb.org/en/ Acesso: 17/03/2019, às $17 \mathrm{~h} 27$.

5 https://www.iadb.org/pt Acesso: 17/03/2019, às 17h27.

6 https://www.caf.com/en/ Acesso: 17/03/2019, às 17h28.
} 
projeção do poder e a modelagem da arquitetura da ordem global. Colocado isto, por que o NBD é um meio de exercício de poder?

O objetivo da pesquisa é compreender como normas e atos institucionais do Banco do BRICS constituem um meio de exercício de poder em várias dimensões. São dados empíricos para a análise o Acordo Constitutivo do NBD e os memorandos de entendimento firmados pelo Banco (normas), bem como os projetos de infraestrutura propostos para receberem financiamento pela instituição (atos). Como recorte do temporal do estudo, serão analisados fatos de 2009 (ano da primeira Cúpula do BRICS) até 2019 (ano da realização do estudo). Outro recorte para a análise é a limitação aos aspectos políticos, isto é, ligados ao conceito de poder, levando em consideração as suas diversas dimensões (a serem explicadas no capítulo teórico). Ademais, não se trata de um estudo das políticas externas dos países membros.

Nos tópicos subsequentes serão abordadas a trajetória do BRICS, a hipótese do estudo e o método empregado.

\subsection{Trajetória do BRICS e Hipótese}

O BRICS é um grupo heterogêneo de países que operam de maneira pragmática para desenvolver interesses comuns por meio de ações conjuntas (Contipelli e Picciau, 2015). Os membros perseguem os próprios interesses, aproveitando a coletividade do grupo, mesmo quando suas ações não são totalmente bem-vindas pelos outros integrantes. O BRICS pode ser visto como uma interação inter-regional entre cinco países membros, que formam um grupo baseado na identificação e busca de certos objetivos comuns no sistema internacional, apesar das diferenças culturais, linguísticas, monetárias e das distâncias geográficas (Naik, 2018). Tradicionalmente, as potências ocidentais constroem e promovem suas próprias regras, ou seja, exortam os países em desenvolvimento a seguirem-nas estritamente (Liu, 2016). Logo, emendar parte dessas regras e escrever novas regras são potenciais objetivos do BRICS.

Em sua origem, o acrônimo BRIC se referia a uma categoria econômica de investimentos, criada pelo grupo financeiro Goldman Sachs, devido ao tamanho das populações, recursos, mercados e territórios dos países integrantes da sigla (Naik, 2018). O diálogo político dentro do BRIC se iniciou em Nova York (setembro de 2006), quando os ministros das relações exteriores se encontraram durante sexagésima primeira Assembleia Geral das Nações Unidas (AGNU) (Stuenkel, 2014; Liu, 2016) por iniciativa 
do embaixador Lavrov. Em maio de 2008, os ministros se reuniram em Ecaterimburgo na Rússia, e em julho de 2008, eles se encontraram durante a Cúpula do G8 no Japão, e combinaram uma cúpula presidencial para o ano seguinte. $\mathrm{Na}$ cidade de Ecaterimburgo (em 2009), Brasil Rússia, Índia e China transformaram a categoria econômica BRIC em grupo político. Em 2011, a África do Sul ingressou no grupo, transformando a sigla BRIC em BRICS.

Conjuntamente o grupo possui $42,58 \%$ da população mundial, $26,46 \%$ do território do globo, 22,53\% do Produto Interno Bruto (PIB) global e contribuiu com mais de $50 \%$ do crescimento econômico do mundo entre 2005 e $2014^{7}$. Ademais, o BRICS é um novo ator internacional, que representa uma inovação política e possui potencial de crescimento, diante da modificação na distribuição de poder que vem ocorrendo no sistema internacional, a partir do começo do século XXI (Stuenkel, 2017). Um aspecto importante a se notar no BRICS é a aproximação e o diálogo entre adversários em questões territoriais, uma vez que há impasses entre China e Rússia ${ }^{8}$, bem como entre China e Índia ${ }^{9}$ acerca de territórios. Ademais, os três países (RIC) juntos podem formar um eixo que desafia a política de Washington ${ }^{10}$.

Apesar de vários analistas mencionarem diferenças ente os membros do BRICS (Abdenur, 2014; Qobo e Soko, 2015; Liu, 2016; Andronova e Shelepov, 2018), pode-se identificar algum grau de convergência de interesses entre os seus integrantes. Peter Ferdinand (2014) examinou a tendência de longa duração da convergência das políticas externas de Brasil, Rússia, Índia, China e África do Sul, para verificar a similaridade de suas posições em temas globais nas votações da Assembleia Geral das Nações Unidas (AGNU), principalmente no Social, Humanitarian and Cultural Affairs Committee e no Special Political and Decolonization Committee (Bas Hooijmaaijers e Stephan Keukeleire, 2016). Foi identificado alto grau de convergência dos BRICS: 82\% entre 2000 e 2011. No entanto, Bas Hooijmaaijers e Stephan Keukeleire (2016) identificaram que não houve aumento no grau de coesão do BRICS nas votações da AGNU, a partir do

\footnotetext{
${ }^{7}$ Fonte: Página Oficial do BRICS para o ano de 2017: https://brics2017.org/English/AboutBRICS/BRICS/ Acesso: 21/10/2018, às 10h34. Obs.: os dados do PIB e sobre o crescimento econômico são de 2015.

8 Fonte: https://www.foreignaffairs.com/articles/china/1967-07-01/tension-sino-soviet-border Acesso: $17 / 10 / 2019$, às $17 \mathrm{~h} 32$.

9 Fonte: https://thediplomat.com/2019/05/china-india-border-talks-remain-stalled-amid-map-burningcontroversy/ Acesso: 17/10/2019, às 17h34.

10 Fonte: https://www.telegraph.co.uk/china-watch/politics/china-russia-india-cooperation/ Acesso: $17 / 10 / 2019$, às $17 \mathrm{~h} 45$.
} 
início do diálogo e da cooperação nos diversos níveis políticos, diplomáticos e burocráticos.

Apesar de os BRICS possuírem agendas políticas muito diferentes entre si, não sendo facilmente identificáveis interesses comuns, além do mais presumível do que verificado interesse de contestar as potências do G7 (Almeida, 2010), é valido notar que os integrantes do grupo não possuem grande número de interesses conflitantes. Por exemplo, na Organização Mundial do Comércio (OMC), os cinco países membros do BRICS estão envolvidos em dezenas de painéis, mas somente em três há conflitos entre os países integrantes do grupo: um Índia contra Brasil, um Índia contra África do Sul e um Brasil contra África do Sul ${ }^{11}$. Já na Corte Internacional de Justiça (CIJ), os países dos BRICS estão envolvidos em mais de dez casos, sendo nenhum deles contra outro membro do grupo ${ }^{12}$.

Ademais, existem ocorrências de ações concertadas, como quando BRICS exibiu uma reação unificada na crise da Criméia (Stuenkel, 2014). Os governos membros apoiaram a Rússia quando houve a intenção de expulsão do país na Cúpula do G20, na Austrália em 2014. De maneira unida, o BRICS criticou a postura dos detratores de Putin no $\mathrm{G} 20^{13}$.

As cúpulas presidenciais do BRICS vêm ocorrendo anualmente desde 2009. Reuniões entre autoridades de âmbito ministerial dos países membros também acontecem, com maior ou menor regularidade, dependendo da temática da pasta. Por exemplo, já foram realizadas reuniões entre autoridades das seguintes áreas: relações exteriores, finanças, comércio, energia, ciência e tecnologia, educação, meio ambiente, agricultura, estatística, cultura, entre outras.

Ao final de cada cúpula presidencial, uma declaração final é assinada pelos chefes de Estados dos países membros. Vários atos diplomáticos foram firmados ao término das referidas cúpulas, bem como ao final das reuniões entre autoridades ministeriais. Atos diplomáticos podem ser tratados, convenções, acordos, ajustes complementares, protocolos, memorandos de entendimento e convênios interinstitucionais ${ }^{14}$. Por exemplo,

\footnotetext{
${ }^{11}$ Fonte:

https://www.wto.org/english/tratop e/dispu e/dispu maps e.htm?country selected=IND\&sense=e Acesso: 12/10/2018, às $01 \mathrm{~h} 38$.

12 Fonte: https://www.icj-cij.org/en/cases-by-country Acesso: 12/10/2018, às 01h42.

${ }^{13}$ Fonte: Chairperson's Statement on the BRICS Foreign Ministers Meeting held on 24 March 2014 in The Hague, Netherlands. Disponível em: http://www.dirco.gov.za/docs/2014/brics0324.html Acesso: $17 / 10 / 2019$, às $18 \mathrm{~h} 16$.

14 MINISTÉRIO DAS RELAÇÕES EXTERIORES, DIVISÃO DE ATOS INTERNACIONAIS. Atos Internacionais, Prática Diplomática Brasileira, Manual de Procedimentos. Brasília, 2010.
} 
já foram assinados os seguintes atos entre os Estados partes: Tratado para o estabelecimento do Arranjo Contingente de Reservas do BRICS, Acordo Constitutivo do Novo Banco de Desenvolvimento, Acordo de Cooperação entre os Governos dos Estados Membros do BRICS na Área de Cultura, Memorando de Entendimento sobre Cooperação em Ciência, Tecnologia e Inovação, Memorando de Entendimento entre as Academias Diplomáticas do BRICS, entre outros ${ }^{15}$.

O Arranjo de Contingência de Reservas (ACR) e o Novo Banco de Desenvolvimento (NBD) são as principais criações institucionais do BRICS (Stuenkel, 2017), por terem uma estrutura decisória própria. O ACR foi criado para prover liquidez para os países em face das dificuldades da balança de pagamentos e de futuras crises econômicas (Contipelli; Picciau, 2015). A instauração do NBD está inserida no contexto de criação de instituições multilaterais que possibilitem aos países em desenvolvimento acesso a recursos financeiros para projetos de infraestrutura (Abdenur, 2014).

No entanto, existe a visão de que o NBD e o ACR seriam iniciativas subimperialistas (Bond, 2016) e não alternativas ao sistema econômico mundial existente, sendo próximas das instituições de Bretton Woods. Tanto o NBD como o ACR possuem o dólar como moeda para os empréstimos, ao invés de um mecanismo de fusão das próprias unidades monetárias: real, rublo, rupia, renmimbi e rand.

Neste contexto, a hipótese é que normas e atos institucionais do NBD constituem um meio de exercício de poder para os membros do BRICS, com implicações nas variadas dimensões do poder (em contraposição a hipótese alternativa de que a instituição seria predominantemente técnica, sem relevantes repercussões em assuntos políticos). $\mathrm{O}$ conceito de poder é um dos mais relevantes das Relações Internacionais e da Ciência Política, sendo também muito relevante para outras áreas como a Filosofia e a Sociologia. Um recorte teórico se fez necessário. Utilizamos principalmente a abordagem de David Baldwin (2013), que analisa o poder em cinco dimensões (escopo, domínio, custos, peso e meios). A justificativa para o uso de tal perspectiva é a amplitude da análise e a possibilidade complementação com outras abordagens, uma vez que o conceito de dimensões reflete diversos sentidos e diferentes categorias para o conceito de poder, conforme se depreende do pensamento do referido autor. No presente contexto, dimensão significa um critério de classificação. Complementamos a visão de Baldwin (2013) com

\footnotetext{
${ }^{15}$ MINISTÉRIO DAS RELAÇÕES EXTERIORES, DIVISÃO DE MECANISMOS INTER-REGIONAIS, DIVISÃO DO AGRUPAMENTO BRICS. Pedido de Acesso à Informação no 09200000520201878. Brasília, 2018.
} 
os estudos de Nye (2011), Barnett e Duvall (2005), Strange (1994), Wight (2002), Berger (2005), Stuenkel (2017b), entre outros, de maneira a identificarmos mais seis dimensões do poder (método de aplicação de meios, incidência, agência vs. estrutura, grau de dominância, geográfica e grau de transição). O conceito de poder e suas dimensões serão explicados no capítulo teórico. O método para análise da hipótese é explicado a seguir.

\subsection{Método}

$\mathrm{Na}$ análise da hipótese é fundamental uma explanação conceitual. Para isto, há um capítulo teórico com explicações acerca do conceito de poder e suas dimensões. Na sequência, há dois capítulos empíricos, que utilizam as dimensões do poder explicadas no capítulo teórico na interpretação do objeto de estudo, o Banco do BRICS. O método de pesquisa é misto, com a utilização de dados quantitativos e qualitativos.

Os dois capítulos empíricos conjuntamente possuem 11 tópicos, um para cada dimensão do poder identificada com a revisão bibliográfica do capítulo teórico, quais sejam: meios, escopo (tema), domínio (atores), custos, peso, agência vs. estrutura, método de aplicação de meios, geográfica, incidência, grau de dominância e grau de transição.

No tópico da dimensão meios de exercício de poder são apresentados argumentos que contrastam com a visão de que o NBD é fundamentalmente técnico, localizando a instituição num contexto internacional mais amplo, no qual se percebe a política de organizações intergovernamentais. O escopo do poder no âmbito do Banco do BRICS é analisado por meio de documentos nos quais se pode auferir os temas mais presentes na instituição, como o de sustentabilidade e de infraestrutura.

A dimensão domínio do poder é abordada principalmente através do estudo de memorandos de entendimento firmados entre o NBD e outras instituições financeiras, de modo a se verificar o potencial de aumento do número de atores envolvidos nas relações de poder do BRICS. No tópico custos do poder, discorre-se acerca dos recursos que cada membro do NBD se comprometeu a fornecer à instituição, comparando tais quantidades com o PIB de cada país integrante da instituição. O peso do poder foca na decisão que determinou a escolha de Xangai como sede do Banco, havendo uma comparação com as sedes de outros bancos multilaterais de desenvolvimento, para se analisar a probabilidade da China ter tido uma maior preponderância na decisão, demonstrando mais poder.

No tópico da dimensão agência vs. estrutura, há a apresentação da estrutura institucional do NBD, de modo a se verificar em que medida prevalece o poder de agência 
(dos atores), bem como se investigar alguma existência de poder estrutural. A quantidade de projetos propostos por cada membro da instituição é considerada. A dimensão método de aplicação de meios de poder é abordada tendo em vista dados normativos e de relatórios do NBD, para se auferir em que medida há aspectos soft (atrativos) e hard (punitivos) na instituição ${ }^{16}$. No tópico dimensão geográfica do poder, são levadas em consideração as características dos projetos de infraestrutura e suas repercussões nos espaços geográficos dos países membros.

A dimensão incidência do poder é estudada tendo por base as durações de execução e financiamento dos projetos do NBD. No tópico grau de dominância, verificase em que medida o poder no âmbito da instituição é exercido de maneira conjunta entre os membros. São considerados dados comerciais, pois há um dispositivo no Acordo Constitutivo do Banco que incentiva um comércio intra-BRICS (Artigo 21, inciso IV). A dimensão grau de transição do poder é abordada com base na análise qualitativa das instituições com as quais o NBD firmou atos diplomáticos, no sentido de se apurar como o Banco do BRICS se localiza num contexto de transição hegemônica entre Estados Unidos e China.

${ }^{16}$ Pode-se visualizar também outras características: o soft power como mais abstrato, moral e ético; e o hard power como mais concreto, escrito e irrefutável. 


\section{UMA SOMA DE ABORDAGENS COMPLEMENTARES SOBRE O CONCEITO DE PODER}

A subjetividade envolve o conceito de poder, o que é típico da área de ciências humanas e sociais, pois vive-se no mundo da doxa (opinião), onde cada autor/autora elabora as suas ideias com base num pensamento próprio, com uma maior ou menor originalidade. Utiliza-se para a presente análise a combinação de abordagens do conceito de poder não contraditórias entre si. Retirando-se as contradições existentes entre as diferentes perspectivas de um conceito, chega-se a um arcabouço teórico mais robusto, pois diversas visões podem ser complementares. Nesse sentido, não buscamos a proposição de "uma teoria única do conceito poder", mas de "uma" teoria do conceito de poder que some abordagens que possuem o potencial de serem complementadas, com aplicação ao objeto de estudo: o Novo Banco de Desenvolvimento (NBD). A mesma proposta do presente capítulo, de apresentação de uma soma de abordagens complementares, pode ser aprimorada em futuras pesquisas sobre o mesmo objeto.

Na política internacional, o poder (Barnett e Duvall, 2005) ocorre de várias formas e não há como capturar toda a sua expressão numa única formulação. O poder dos Estados (Baldwin, 2013), no Século XVIII, era concebido com recursos materiais bem definidos como população, território, riqueza e forças armadas. Com o avanço da literatura, o poder passou a ser visto não apenas como "recurso" ou "capacidades", mas também foi enquadrado numa abordagem relacional, ligada à causalidade. A perspectiva causal concebe o poder como uma relação, real ou potencial, na qual o comportamento de um ator é pelo menos em parte mudado pelo comportamento de outro ator (poder como variável independente). Nesse contexto, comportamento inclui crenças, atitudes, preferências, opiniões, expectativas ou predisposições para agir.

A definição relacional ou comportamental (Nye, 2011) analisa o poder pelas consequências resultantes da ação (estudo ex post). No entanto, como tomadores de decisão precisam de um conceito de poder que sirva de guia para a ação, ainda é útil a definição de poder como recurso, anterior à ação (estudo ex ante). A abordagem do poder como recurso é um atalho útil para o tomador de decisão. Em geral, prefere-se a hipótese de que países dotados com muitos recursos de poder possuem uma probabilidade maior de alcançar os seus resultados de interesse, quando lidam com países fracos em tais recursos. Num impasse de interesses entre Rússia e Finlândia, não se espera que o país nórdico prevaleça em detrimento do eslavo, por exemplo. 
Na ótica do "recurso", o poder é possuído; na ótica relacional, o poder é exercício e causa resultados. Segundo Nye (2011), somente faz sentido dizer "possuir poder" se for respondida a pergunta: "para fazer o quê?". A análise fica mais precisa com a especificação de "quem" são os atores envolvidos, bem como de "quais" são os tópicos relacionados. Uma política estatal depende de um conceito de poder especificado, de modo a deixar claro quem ganha o quê, como, quando e onde. Em outros termos, as condições de possibilidade do exercício de poder são centrais para uma análise mais profunda.

A perspectiva relacional permite a visualização do poder em várias dimensões, sem excluir a relevância dos recursos. Baldwin (2013) identificou cinco dimensões do poder para ótica relacional: escopo, domínio, peso, custos e meios. Na análise a posteriori da ação (perspectiva relacional), os meios para o exercício do poder são os recursos de fato utilizados, diferindo da análise a priori (perspectiva do poder como recurso), apenas na aplicabilidade do recurso, que neste último caso, é potencial.

Na política internacional, o poder é como as cartas mais valiosas num jogo de baralho (Baldwin, 2013). Na política, como num jogo de cartas, os atores precisam saber qual jogo estão jogando para avaliarem o seu próprio poder. As cartas mais valiosas no poker não são as mais valiosas no bridge. Logo, a análise do poder possui o problema da mensuração. Na política, não há um correspondente ao capital na economia, porque não há uma medida padronizada que reduza as várias dimensões do poder em uma só dimensão. Por isso, na análise do poder é fundamental especificar as dimensões do poder presentes num caso concreto.

Combinando as abordagens de Baldwin (2013), Nye (2011), Barnett e Duvall (2005), Strange (1994), Wight (2002), Berger (2005), Stuenkel (2017b) e outros, chegamos a 11 dimensões do poder, quais sejam: escopo, domínio, peso, custos, meios, método de aplicação de meios, incidência, agência vs. estrutura, grau de dominância, geográfica e grau de transição. Tratam-se de ideias fundamentais para a explicação da seguinte hipótese, que será analisada empiricamente nos capítulos subsequentes: normas e atos institucionais do NBD constituem um meio de exercício de poder em várias dimensões. Seguem abaixo as explanações para cada dimensão e para o conceito de fungibilidade, que trata da conversibilidade entre as dimensões.

\subsection{Dimensão Escopo do Poder}


O escopo refere-se ao tema no qual um ator exerce poder sobre outro (Baldwin, 2013). Por exemplo, no tema da economia, o Japão possui maiores condições de exercer poder sobre outro ator, do que no tema militar. O inverso acontece com a Coreia do Norte. O escopo pode ser especificado em casos. Por exemplo, no tema da economia há o caso das sanções econômicas do Estados Unidos em relação à Venezuela ${ }^{17}$, há o caso da taxação de produtos chineses também por partes do Estados Unidos e o revês chinês ${ }^{18}$, entre outros.

A quantidade de temas possíveis em que o poder é exercido é indeterminada, sendo qualquer listagem meramente exemplificativa, por maior que seja. Uma opção é listar temas conforme as pastas ministeriais de um Estado: relações exteriores, finanças, comércio, energia, ciência e tecnologia, educação, meio ambiente, agricultura, estatística, cultura, entre outras. No entanto, um tema também pode perpassar vários outros (caso de issue-linkage), como ocorre com as instituições, as quais não são necessariamente restritas a uma única temática.

\subsection{Dimensão Domínio do Poder}

O domínio refere-se ao número de atores sujeitos ao poder de outro ator (Baldwin, 2013). Há como o domínio do poder de um Estado alcançar uma região do globo, sendo irrelevante em termos de influência para outras regiões. Por exemplo, o domínio do poder da Rússia é menor do que o da antiga União Soviética.

As definições de escopo e domínio de Baldwin (2013) são invertidas em relação às definições de escopo e domínio de Nye (2011), que define escopo como os atores envolvidos na relação de poder e domínio como o tema em questão. Como Baldwin desenvolveu mais dimensões para o conceito de poder do que Nye, neste ponto de contradição entre autores, preferimos optar por considerar as definições do primeiro.

Numa instituição com muito membros, como a União Europeia, o domínio do poder envolve no mínimo os seus $28 \operatorname{membros}^{19}$, havendo ainda probabilidade de uma decisão do bloco europeu influenciar muitos países externos ao processo de integração.

\footnotetext{
${ }^{17}$ Fonte: https://www.dw.com/pt-br/eua-aplicam-novas-san $\% \mathrm{C} 3 \% \mathrm{~A} 7 \% \mathrm{C} 3 \% \mathrm{~B} 5$ es- $\% \mathrm{C} 3 \% \mathrm{~A} 0$-venezuela/a$\underline{40246608}$

${ }^{18}$ Fonte: https://www.bbc.com/news/business-45255623

${ }^{19}$ Incluindo o Reino Unido, que está em processo de desligamento da União Europeia.
} 


\subsection{Dimensão Peso do Poder}

$\mathrm{O}$ peso refere-se à probabilidade do comportamento de um ator ser afetado pelo poder de outro (Baldwin, 2013). Um Estado que possui 90\% de chances de alcançar o seu objetivo numa negociação comercial é mais poderoso do que outro Estado que possui $30 \%$ de chances, mantidas as mesmas condições (ceteris paribus). Entretanto, há o problema da mensuração da probabilidade de um ator alterar o comportamento de outro.

\subsection{Dimensão Custos do Poder}

Os custos, tanto os do ator que exerce o poder quanto os do ator que sofre o poder, são relevantes para a avaliação da influência (Baldwin, 2013). É custoso ou barato para um ator "A" influenciar um ator "B"? É custoso ou barato para um ator "B" atender as demandas do ator "A"? É mais poderoso o ator que consegue exercer mais poder de forma barata do que o ator que só consegue exercer poder de forma cara, mantidas as mesmas condições (ceteris paribus). Caso um ator "A" consiga com que um ator "B" faça algo que é custoso para "B”, então "A" é mais poderoso do que um ator que só consegue que "B" pratique atos baratos para "B". Outra possibilidade do ator "A" demonstrar o seu poder é aplicando custos ao ator "B" por não cumprimento de suas demandas.

Deste modo, chega-se à seguinte gradação do poder conforme os custos na relação entre "A" e "B": ato barato para "A" e ato custoso para "B" > ato barato para "A" e ato barato para "B" > ato custoso para "A" e ato custoso para "B" $>$ ato custoso para "A" e ato barato "B". Assim, pode-se relacionar a dimensão custos com o conceito de interdependência.

Dependência significa que um Estado é afetado significativamente por forças externas (Keohane e Nye, 2012). Interdependência é a dependência mútua, referindo-se a situações caracterizadas por efeitos recíprocos entre países ou entre atores em diferentes países. Interconectividade é diferente de interdependência. Os efeitos das transações na interdependência dependerão dos constrangimentos ou dos custos associados a esses efeitos. Um país que importa todo o seu petróleo é mais dependente de um contínuo fluxo de tal produto do que um país que importa principalmente itens de luxo. Onde há reciprocidade nos efeitos custosos das transações, há interdependência. Nas interações onde não há efeitos dispendiosos, há simplesmente interconectividade. Na interdependência não há apenas benefício mútuo. A maioria dos casos de 
interdependência se encontra no continuum entre a dependência puramente simétrica e a puramente assimétrica.

Os conceitos de sensibilidade e de vulnerabilidade são importantes para se entender a função do poder na interdependência (Keohane e Nye, 2012). Sensibilidade reflete num país os imediatos custos internos, decorrentes de mudanças ocorridas no exterior, antes que se implementem políticas alternativas. Vulnerabilidade é o custo dos ajustes feitos por um país para lidar com a mudança ocorrida no exterior, ou seja, é o custo imposto que o ator sofre após suas políticas terem sido alteradas para lidar com a mudança externa. A sensibilidade é menos relevante como fonte de poder do que a vulnerabilidade. Vale ressaltar que um país mais poderoso e menos dependente, em termos agregados, pode ser mais fragmentado internamente, dificultando a coordenação de interesses (Keohane e Nye, 2012).

\subsection{Dimensão Meios de Exercício do Poder}

Os meios indicam os recursos utilizados ou caminhos para o exercício do poder. Baldwin (2013) lista quatro meios: simbólicos, econômicos, militares e diplomáticos. O referido autor apresenta os seguintes exemplos: são meios simbólicos informações, discursos, propagandas e narrativas; são meios econômicos o aumento e a redução da oferta de bens e serviços de um país para outros; são meios diplomáticos as negociações e as representações; são meios militares as forças armadas (somando-se a utilização de recursos humanos e materiais).

As listas acima (tanto a de meios como a de exemplos) não são taxativas. Pode-se identificar outros meios e exemplos através de reflexões e de observações empíricas. As sanções econômicas e a produção obviamente são meios econômicos. Também são meios diplomáticos as elaborações de atos diplomáticos como memorandos de entendimento, acordos, protocolos e tratados.

Pode-se adicionar à lista acima, os meios tecnológicos para o exercício do poder. Além disso, os meios listados acima não são excludentes. Por exemplo, é possível um Estado exercer poder sobre outro, firmando um acordo para venda de seus bombardeiros, por serem tecnologicamente mais avançados, defendendo um discurso da relevância de tal armamento para a defesa. Há ligação entre os meios econômicos (produção, venda e compra), militares (aeronave de combate), diplomáticos (acordo), tecnológicos (tecnologia da aeronave) e simbólicos (discurso sobre defesa). Ademais, o fortalecimento 
de um meio pode prejudicar outro(s). A União Soviética (Baldwin, 2013) foi um exemplo de Estado que ficou mais forte quanto aos meios militares, em detrimento do enfraquecimento de seus meios econômicos para o exercício do poder.

Outro meio a ser acrescentado na lista acima é o institucional. Instituições internacionais (Krasner, 1982) podem ser definidas como conjuntos implícitos ou explícitos de princípios, normas, regras e procedimentos de tomada de decisão. Princípios são crenças sobre fatos. Normas são padrões de comportamentos definidos em termos de direitos e obrigações. Regras são prescrições específicas para a ação. Procedimentos de tomada de decisão são práticas para fazer e implementar a escolha coletiva. Os atores básicos são os Estados.

No presente estudo, não igualamos o conceito de instituições ao de regimes, pois os regimes são apenas um tipo de instituição, delimitado numa dada área das relações internacionais, na qual há certa convergência de expectativa no comportamento dos atores, conforme Quadro 1 abaixo. A especificação do tema e a convergência de expectativa são características que não fazem parte de qualquer instituição. Por exemplo, a governança (Rosenau, 2000) é um conjunto implícito ou explícito de princípios, normas, regras e procedimentos de tomada de decisão, sem restrição a apenas uma área ${ }^{20}$.

Quadro 1: Instituições

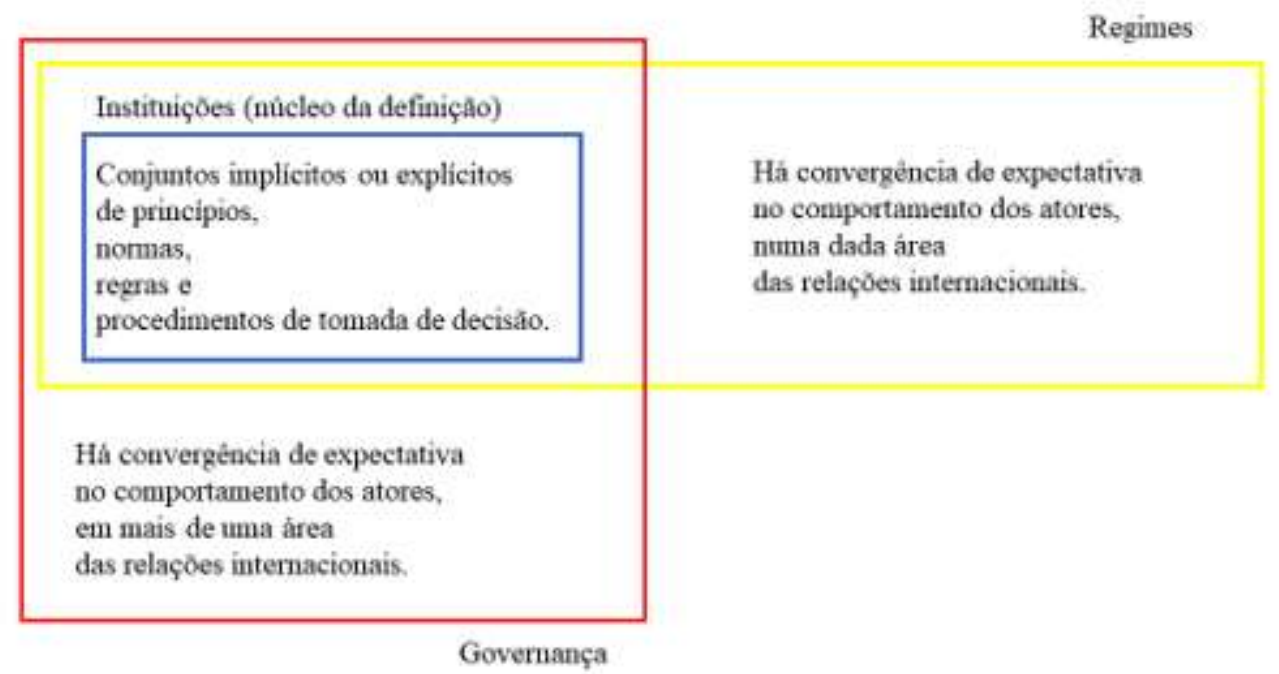

Fonte: elaboração própria com base nas definições de Krasner (1982) e Rosenau (2000).

\footnotetext{
${ }^{20}$ A literatura sobre regimes internacionais é vasta. Por exemplo, Alter e Raustiala (2018) trabalham com o conceito de complexos de regimes, os quais são resultados de conexões ente temas, cujas respostas afetarão os outros regimes. Como o conceito de regime na presente pesquisa é apenas acessório para o entendimento do conceito de instituições, não aprofundamos nesta discussão.
} 
Para Ikenberry (2001), as instituições resolvem problemas funcionais, facilitam a cooperação, reduzem as incertezas e servem como mecanismos de controle do poder. No entanto, instituições (Barnett e Duvall, 2005) são também meios de exercício do poder porque os arranjos institucionais afetam os comportamentos dos atores, limitando oportunidades, moldando a formação da agenda, congelando privilégios e vieses, balizando as possibilidades de escolha dos atores. Os arranjos institucionais podem formalizar linhas de responsabilidades, divisões do trabalho e estruturas que geram dependência. Um ator "A", que ocupe uma posição de relevância numa dada instituição, por meio de suas ações acaba por exercer poder sobre um ator "B", imerso no mesmo contexto institucional.

Um arranjo institucional (Barnett e Duvall, 2005) pode determinar quais temas serão considerados e quais não serão. As agendas permitem alguns atores promoverem seus interesses e ideias, exercendo controle sobre outros, limitando a habilidade de outros atores no engajamento de ações coletivas eficientes. Instituições são criadas para gerar colaboração e cooperação, mas também produzem resultados com "vencedores" e "perdedores", na medida em que os "ganhos" são desigualmente distribuídos. Com a intenção do viés, grandes potências estabelecem instituições internacionais visando a preservação de seus interesses e de suas posições de vantagem no futuro, eliminando potenciais pontos de oposição.

O NBD é uma instituição porque possui princípios, normas, regras e procedimentos de tomada de decisão. O Acordo sobre o Novo Banco de Desenvolvimento apresenta: os seus princípios expressos (bancários e operacionais) nos artigos $3^{\circ}$ e $21^{\circ}$; as normas e as regras dos principais componentes de sua estrutura (Conselho de Governadores e Conselho de Diretores) nos artigos $11^{\circ}$ e $12^{\circ}$; e os seus procedimentos de tomada de decisão (maioria simples e maioria especial) nos artigos $6^{\circ}, 44^{\circ}$ e $46^{\circ}$. A hipótese de que o NBD é um meio institucional de exercício do poder será testada nos demais capítulos da presente pesquisa.

\subsection{Dimensão Método de Aplicação de Meios (hard power, soft power e smart power)}

É impreciso definir meios militares e econômicos como hard power, meios institucionais e culturais como soft power, e a soma de tais meios como smart power. As definições de soft power, hard power e smart power concentram-se muito mais nos métodos de emprego dos recursos de poder do que nos recursos em si. Conforme Nye 
(2011), soft power envolve atração e persuasão, hard power envolve coerção e pagamento, smart power envolve estratégia.

Nye (2011) admite uma certa associação entre tais poderes e determinados recursos. Segundo o referido autor, o soft power de um país repousaria principalmente em três recursos básicos: sua cultura (quando é atrativa a outros), seus valores políticos (quando eles são presentes no ambiente doméstico e no exterior) e na sua política externa (quando outros atores a veem como legítima e com autoridade moral). O hard power repousaria principalmente em recursos militares e econômicos. No entanto, tais associações não são perfeitas.

Os recursos militares, por exemplo, são usados normalmente como meios de se exercer hard power, no entanto, podem ser também utilizados como soft power, como se percebe nos dizeres do famoso cartaz alemão na França ocupada, durante a Segunda Guerra Mundial: "populations abandonnées, faites confiance au soldat allemand!". Trata-se de um meio militar utilizado juntamente com o meio simbólico da propaganda. Por outro lado, as fontes típicas de soft power (Nye, 2011), que incluem fatores como instituições, ideias, valores e cultura, podem ser úteis para um exército numa guerra. A moral pode afetar o desempenho das forças armadas num combate (situação na qual o hard power é exercido).

Os termos coerção, pagamento, persuasão, atração e estratégia evidenciam o aspecto relacional das definições de smart power, hard power e soft power. Coerção envolve o uso ou ameaça do uso da força. Pagamento relaciona-se com a entrega ou promessa de entrega de uma recompensa.

A atração (Nye, 2011) envolve três qualidades: benignidade, competência e carisma. Ser conhecido como benigno gera credibilidade. Ser percebido como competente produz admiração e respeito. Ser considerado carismático (no sentido de Max Weber) resulta em inspiração. As três qualidades do conceito de atração são fundamentais para converter a utilização dos recursos de poder em mudanças de comportamento de outros atores. Sem a percepção de tais qualidades, a utilização de um recurso pode resultar em indiferença ou até repulsa por parte dos outros atores, o que é oposto da ideia de soft power. É possível que a utilização de um mesmo recurso de poder por parte de um agente resulte em atração para uns e repulsa para outros.

A persuasão (Nye, 2011) é a utilização de argumentos para influenciar as ações e as crenças de outros atores, sem ameaça de uso da força e sem promessa de pagamento. Persuasão quase sempre envolve algum grau de manipulação, com a ênfase sobre alguns 
pontos e desconsideração de outros. A argumentação envolve colocações sobre fatos e valores, de modo a enquadrar determinado tema de forma convincente, conforme os interesses do ator que argumenta. A persuasão se torna desonesta se houver fraude. Uma argumentação fundamentada pode convencer, mesmo se proposta por um inimigo.

Smart power (Nye, 2011) é a combinação da coerção e do pagamento (do hard power) com a persuasão e a atração (do soft power), dentro de estratégias em variados contextos. Smart power envolve estratégias que relacionam meios e fins para a conversão dos recursos de poder nos comportamentos resultantes de interesse, em diferentes contextos. A utilização do smart power passa pelo entendimento da ampla gama de possibilidades de usos dos recursos de poder.

Há cinco passos para a elaboração de uma estratégia de smart power (Nye, 2011): $1^{\circ}$ ) Definição clara dos objetivos, após um longo debate para os propósitos do próprio poder; $2^{\circ}$ ) Elaboração precisa de inventários de recursos de poder disponíveis, conforme as avaliações de diferentes contextos na política internacional (contextos diferentes implicam em inventários diferentes); $3^{\circ}$ ) Avaliação dos recursos de poder e das preferências dos alvos a serem influenciados (por exemplo, conforme Rumsfeld pontuou, para os Estados Unidos vencer a guerra contra o "Terror" é preciso que o número de terroristas mortos pelo hard power americano seja maior do que o número de pessoas recrutadas pelo soft power dos grupos terroristas); $4^{\circ}$ ) Combinar comportamentos de soft power e hard power; $5^{\circ}$ ) Avaliar as probabilidades de sucesso, tanto no nível estratégico como no nível tático de uma tentativa de influência.

Por exemplo, a China (Nye, 2011), que cresce militar e economicamente, exerce smart power ao investir deliberadamente em soft power como forma de fazer o seu hard power menos ameaçador a seus vizinhos. O crescimento econômico da China pode ser utilizado tanto como hard power, ao permitir sanções e restrições de acesso ao seu mercado, quanto como soft power, ao proporcionar uma atração por ser um exemplo de performance econômica de sucesso. As forças armadas chinesas podem ser utilizadas como hard power (ao vencer uma batalha), ou como soft power (conquistando corações e mentes), dependendo do tema em questão. Tal estratégia se enquadra na diplomacia chinesa com o lema "ascensão pacífica" (Becard e Castro, 2013). 


\subsection{Dimensão Incidência do Poder (direta ou indireta)}

Há possibilidade de o poder operar direta ou indiretamente. Na concepção direta (Barnett e Duvall, 2005), o poder atua imediatamente numa relação social específica, sendo o mecanismo causal que conecta as ações entre atores, havendo uma relação direta de causa e consequência. Na concepção indireta, o poder opera à distância, seja temporal ou espacial, não havendo relação específica e direta entre atores, pois o mecanismo causal é indireto.

O meio institucional de poder (Barnett e Duvall, 2005) é relacional e indireto. O referido meio de poder, seja numa instituição formal ou informal, frequentemente opera de maneira indireta. As regras e os procedimentos de tomada de decisão podem moldar os resultados em favor de um grupo em detrimento de outros. Os efeitos operam através do tempo e a distância, de uma maneira não necessariamente antecipada ou intencional por parte do arquiteto da instituição (do design institucional).

Conforme a diplomacia é exercida (de modo tradicional ou público), evidencia-se também diferentes incidências do poder. A diplomacia tradicional (Nye, 2011) é fechada em "gabinetes", com o envio de mensagens de um Estado para o outro, frequentemente confidenciais. O governo "A" se comunica com o governo "B", para tentar exercer poder de forma direta. Na diplomacia pública, um governo se comunica com diversos atores ao mesmo tempo, governos de vários Estados, organizações internacionais, sociedades civis, de modo que a informação transite por várias rotas. Assim, a diplomacia pública visa o exercício do poder de forma indireta, pois leva mais tempo para a produção de efeitos. A informação transmitida que é percebida como propaganda se torna contraproducente, prejudicando a credibilidade do ator. Logo, o soft power, com atração ou persuasão, pode operar tanto de maneira direta como indireta.

\subsection{Dimensão Agência vs. Estrutura}

Strange (1994) explica de maneira conjunta os conceitos de relação, estrutura e poder. O poder relacional seria capacidade de um ator "A" conseguir que um ator " $B$ " faça o que não faria se não fosse a influência de "A". Em outras palavras, o poder relacional ocorreria quando um agente consegue fazer valer sua vontade. Já o poder estrutural formaria a arquitetura na qual os atores se relacionam, sejam Estados, pessoas ou empresas. O poder relacional de cada ator e a relação entre eles seriam determinados 
em alguma medida pela estrutura em torno da relação. Seriam fontes do poder estrutural: o controle sobre conhecimento, segurança, finanças e produção.

Discordamos da referida autora, no ponto que ela utiliza a expressão "poder relacional" em oposição a "poder estrutural”, e não em oposição a "poder como recurso". Faz mais sentido o "poder estrutural" ter como oposição o "poder do agente", dentro do debate agente-estrutura, bem como faz mais sentido a expressão "poder relacional" ter como oposição a expressão "poder como recurso". O "poder relacional” utiliza o conceito de poder como variável independente, uma vez que após a ocorrência de uma relação verifica-se em que medida um ator exerceu poder sobre outro (o poder é uma causa de um efeito). O "poder como recurso" utiliza o conceito de poder como variável dependente, uma vez que não se verifica em que medida um ator exerceu poder sobre outro, mas sim, o que faz um ator ser poderoso (o poder é um efeito de uma ou mais causas).

O "poder estrutural" determina tanto identidades e interesses como resultados. Uma estrutura pode ser analisada como variável independente, numa perspectiva "relacional do poder" (verifica-se em que medida o "poder estrutural" é a causa de um efeito). Uma estrutura pode ser analisada também como variável dependente, numa perspectiva do "poder como recurso" (verifica-se em que medida o "poder estrutural" é o efeito de uma ou mais causas). O "poder do agente" é aquele que os atores possuem e exercem, apesar da estrutura. $\mathrm{O}$ poder de um agente pode ser analisado como variável independente, numa perspectiva "relacional do poder" (verifica-se em que medida o "poder do agente" é a causa de um efeito). O poder de um agente pode ser analisado também como variável dependente, numa perspectiva do "poder como recurso" (verificase em que medida o "poder do agente" é o efeito de uma ou mais causas).

Apesar da discordância, reconhecemos muita qualidade no trabalho de Strange (1994). A referida autora identifica quatro áreas na dimensão estrutural (no sistema internacional): conhecimento, produção, finanças e segurança. Conforme o objeto de estudo e o enfoque analítico, pode-se verificar outros campos nos quais o poder estrutural é verificado. Sem a necessidade de seguir ponto por ponto da categorização de Strange, é possível produzir ideias inspiradas na visão da autora, que conferiu ao poder estrutural múltiplas áreas.

O poder estrutural de certa forma alcança também a área das instituições (outra adaptação viável é aplicar o conceito de poder estrutural numa instituição específica e não apenas no sistema internacional como um todo). Conforme Stuenkel (2017), no Fundo 
Monetário Internacional (FMI) em 2006, Brasil, China e Índia tinham menos influência no Fundo do que Holanda, Bélgica e Itália, apesar de terem economias muito maiores. Apesar das mudanças na economia global no início do século XXI, a estrutura institucional de uma das principais organizações criadas no âmbito do sistema Bretton Woods não sofreu alterações significativas até a reforma histórica de 2010, quando mais de $6 \%$ das cotas foram direcionadas aos maiores emergentes. A China passou a ocupar a terceira posição entre os principais acionistas, e Rússia, Índia e Brasil entraram nas dez primeiras colocações entre os acionistas mais relevantes.

Nye (2011) faz uma revisão de literatura sobre as três faces do poder relacional no debate estrutura vs. agência, quais sejam: o comando da mudança (Dahl), o controle da agenda (Bachrach e Baratz) e o estabelecimento de preferências (Lukes). A primeira face, o comando da mudança, refere-se à alteração do comportamento dos outros atores em sentido contrário às suas preferências iniciais. Para mensurar o poder da primeira face é necessário saber a intensidade das preferências iniciais e o quanto elas foram alteradas pelo exercício do poder em questão (hard power). A segunda face, o controle da agenda, trata das limitações institucionais que restringem a importância das preferências, ao deixar temas de fora dos processos de tomada de decisão. $O$ ator pode ter ciência ou não do poder no qual está sujeito. Tal parte constitui em parte o soft power, a habilidade de conseguir o que se quer por enquadramento da agenda, persuasão e atração. No entanto, se a instituição leva a coerção ou pagamentos, trata-se somente de mais uma instância da primeira face do poder. A terceira face, o estabelecimento de preferências, molda as crenças e as percepções básicas e iniciais dos atores, sem necessidade de mudanças. Entretanto, é difícil verificar o que constitui ou não uma formação voluntária de preferências. A segunda e a terceira face enfatizam as limitações impostas pela estrutura, enquanto a primeira realça as capacidades dos agentes.

Segundo Barnett e Duvall (2005), o poder estrutural molda as condições de existência dos atores de duas maneiras. Primeiro, as posições dos atores na estrutura não resultam numa equidade social, de modo que as diferentes posições estruturais alocam de maneira desigual as capacidades. Segundo, a estrutura molda os interesses e as percepções que os atores têm de si mesmos. Como consequência da distribuição assimétrica de privilégios na estrutura, os interesses dos atores são afetados de maneira a constrangê-los a aceitarem sua situação de dominação e o status quo. Portanto, o poder estrutural define as capacidades e os interesses dos atores, sendo constitutivo e direto. 
Já a teoria da Estruturação (Wendt, 1987) define agentes e estruturas como mutuamente constitutivos, ainda que entidades ontologicamente distintas (são codeterminados e mutuamente dependentes). Estruturas sociais são o resultado de ações humanas intencionais e não intencionais, bem como tais ações pressupõem uma mediação pelo contexto estrutural. Os fenômenos sociais não são consequência apenas da agência (reducionismo, voluntarismo e individualismo) nem são resultado apenas da estrutura (reificação, determinismo e estruturalismo), pois ambos são simultaneamente envolvidos na produção dos referidos fenômenos.

A partir da perspectiva da teoria da Estruturação (Wendt, 1987) dois tipos de perguntas são relevantes para explicar a ação social: “Como a ação X é possível?" e "Por que X ocorreu ao invés de Y?". "How-questions” dizem respeito ao domínio do possível e "why-questions" se referem ao domínio do real. Enquanto a análise estrutural explica o possível (a possibilidade de eventos acontecerem), a análise histórica explica o real (os eventos que realmente aconteceram). No entanto, "how-questions" são necessárias para responder "why-questions", pois para saber porque o Estado fez $\mathrm{X}$ ao invés de $\mathrm{Y}$, é preciso saber como o Estado e suas escolhas são possíveis em primeiro lugar.

A análise histórica (Wendt, 1987) é necessária para explicar a emergência e a persistência de condições estruturais, as quais mediam e condicionam as possibilidades de ação dos Estados. Dada a dificuldade de se fazer uma pesquisa histórica e estrutural simultaneamente, a análise histórico-estrutural requer a utilização de um modo explanatório por vez, isto é, temporariamente considerar agente e estrutura como dados, um de cada vez, para examinar os efeitos de um no outro.

\subsection{Dimensão Grau de Dominância (power over, power with e power to)}

Conforme o grau de dominância presente numa relação entre atores, o poder se manifesta de diferentes formas. Power over (Berger, 2005) refere-se ao modelo tradicional de dominância, onde o processo de tomada de decisão é caracterizado pelo controle, pela instrumentalidade e pelo auto-interesse. Power with trata-se de um modelo de empoderamento, no qual o diálogo, a inclusão, a negociação e o compartilhamento do poder guiam a tomada de decisão. Power to indica uma resistência ao modelo dominante e um ativismo que possibilita a prática de ações visando os próprios interesses (Berger, 2005). 
Numa relação de dominância, o ator mais poderoso exercer power over e o ator menos poderoso, se resistir, exerce power to. Caso não haja dominância na relação entre os atores, eles exercem power with. Mesmo se um Estado for mais poderoso do que muitos outros, é possível que ele opte por exercer power with outros Estados, ao invés de power over.

A legitimidade de uma potência hegemônica passa pela sua habilidade de prover bens públicos (Prantl, 2014). Logo, para um hegemon se manter é necessário não apenas o exercício de power over, com a limitação de bens públicos para os atores menos poderosos, mas também é preciso o exercício de power with, permitindo a outros países um exercício de poder conjunto.

Um país pequeno pode se beneficiar da paz em sua região (Nye, 2011), da liberdade de navegação nos oceanos, do controle de doenças infecciosas, ao mesmo tempo que uma potência hegemônica não diminui os benefícios para si ou para os outros. É claro que bens públicos puros são caros. Quando alguns países são excluídos, os bens são parcialmente públicos, havendo situações em que os bens beneficiam um clube restrito de países. Deste modo, o que é bom para uma potência hegemônica não é bom para muitos outros países.

Problemas globais como mudanças climáticas, epidemias e terrorismo não podem ser resolvidos por um único Estado (Nye, 2011). Assim, criações de instituições e coalizões internacionais são necessárias para lidar com tais desafios. Nesse sentido, poder se torna um jogo de soma positiva (não de soma zero). Não é suficiente pensar em "poder sobre" outros (power over). É preciso também pensar em "poder para" atingir os objetivos (power to), o que envolve "poder com" os outros atores (power with). Em muitos temas transnacionais, um ator, ao empoderar outros atores, pode contribuir para o atingimento de seus próprios objetivos.

As instituições (Nye, 2011) possibilitam a existência de redes entre Estados. A centralidade de um ator na rede é uma fonte/recurso de poder, mas não necessariamente para imposição de resultados (power over). Redes proporcionam poder para (power to) alcançar resultados em ações conjuntas com outros (power with). Com um hub na rede, os atores não se comunicam diretamente uns com os outros, pois dependem do ator que ocupa a posição de $h u b$ na rede. A arquitetura da rede pode evitar comunicação direta entre certas partes da rede. Os atores que fazem a ponte entre atores podem explorar sua posição na rede ao controlar determinadas comunicações (exercício de power over). Outro aspecto importante para o poder da rede é a sua extensividade. Mesmo redes com 
laços fracos podem disseminar informação, aumentando a possibilidade de exercer "poder com" (power with).

\subsection{Dimensão Geográfica (poder terrestre, poder marítimo, poder aéreo e poder espacial)}

A relevância da dimensão geográfica do poder é explicada pela geopolítica das relações internacionais. A geopolítica (Kelly, 2016) repousa sobre as posições dos países e dos recursos naturais e como tal distribuição pode afetar as ações e as políticas externas dos Estados. São características geográficas elementos como os tamanhos e as localizações dos países, as topografias e as distâncias. A partir de tal perspectiva surgem os conceitos de poder terrestre, poder marítimo, poder aéreo e poder espacial.

Wight (2002) apresenta exemplos históricos das dimensões geográficas do poder. No século XVIII, o Reino Unido se tornou a potência com maior poder marítimo quando conseguiu derrotar as marinhas da Espanha e da França. Houve uma Pax Britannica no século XIX, quando os britânicos possuíam o domínio dos mares, com capacidade de transportar tropas e mercadorias pelos mares, bem como de evitar que seus rivais fizessem o mesmo, tendo condições também de exercer pressão sobre qualquer Estado banhado pelo mar. A predominância britânica nos mares acabou formalmente com a Conferência de Washington em 1922, com o estabelecimento da razão $5 / 5 / 3^{21}$ para as marinhas do Estados Unidos, Reino Unido e Japão, respectivamente. Após a entrada do Estados Unidos na Segunda Guerra Mundial, os aliados controlaram o comércio mundial. Navios de países neutros precisavam de autorização das Potências aliadas para navegarem.

Em suas respectivas épocas, a França de Napoleão e a Alemanha de Hitler foram as potências com maior poder terrestre, com políticas externas guiadas pelo interesse de expansão territorial (Wight, 2002). Quando uma potência anexa um território de um Estado mais fraco geralmente há um argumento econômico ou moral para justificar a tomada do território, como a "retificação de fronteiras". A Alemanha Nazista buscava uma área pivotal no globo, a qual abrangia partes da Europa e da Ásia. Trata-se de uma vasta planície irrigada por rios, que é inacessível à navegação marítima, sendo imune ao poder marítimo. Após a Segunda Guerra Mundial, o Estados Unidos se tornou a potência com maior poder marítimo e a União Soviética a potência com poder maior terrestre.

\footnotetext{
${ }^{21}$ A razão 5/3/3 significa, no contexto em tela, que para cada 5 unidades navais americanas, os britânicos e os japoneses poderia ter 3 unidades.
} 
Com a Primeira Guerra Mundial surgiu o poder aéreo (Wight, 2002). Na Itália, no Reino Unido e nos Estados Unidos foi desenvolvida uma teoria do poder aéreo, a qual defendia que os aviões seriam decisivos nas guerras, com condições de destruir cidades, indústrias e a economia de qualquer país. Áreas imunes a ataques passaram a ficar vulneráveis. Durante a Segunda Guerra Mundial, os bombardeiros foram mais efetivos contra o Japão do que contra a Alemanha, que conseguiu aumentar a sua produção bélica a cada ano. Os poderes terrestre, marítimo e aéreo se tornaram interdependentes. Em conflitos futuros, as aeronaves podem ser substituídas por mísseis numa guerra total, lançados a partir de bases terrestres ou marítimas.

Para a análise de Wight (2002) cabe uma complementação. O poder terrestre de um Estado não se restringe a seu exército, pois também envolve a extensão territorial do país, a continuidade ou descontinuidade do território, a quantidade de recursos naturais presentes em suas terras, bem como o espaço geográfico transformado, isto é, as infraestruturas territoriais existentes (cidades, indústrias, fazendas, ferrovias, rodovias, oleodutos/gasodutos, malhas elétricas, redes de comunicações, entre outras).

O poder marítimo de um Estado não se limita à sua marinha, pois também abrange a extensão de seu litoral e de seu mar territorial, a presença ou não de insularidade, a quantidade de recursos naturais presentes em seus mares, bem como o espaço geográfíco transformado, ou seja, as infraestruturas marítimas existentes, inclusive para suporte de rotas marítimas de comércio (portos, oleodutos/gasodutos, cabos submarinos de transmissão de energia e comunicações, entre outras).

O poder aéreo de um Estado não se reduz à sua aeronáutica, pois também inclui a extensão de seu espaço aéreo ${ }^{22}$ (o que depende do tamanho de seu território e de seu mar territorial), bem como o espaço geográfico transformado com infraestruturas que forneçam suporte para operações aéreas (aeroportos, pistas de pouso, radares, equipamentos que monitoram as condições atmosféricas, entre outras).

O poder espacial de um Estado não se reduz às forças espaciais (militares) ${ }^{23}$, pois engloba a sua órbita geoestacionária (aquela acima do território do país), bem como o espaço geográfico transformado com infraestruturas que forneçam suporte para operações

\footnotetext{
${ }^{22}$ Neste ponto, nos referimos à situação em que o Estado exerce soberania sob todo o seu espaço aéreo, o que não foi o caso do Iraque de 1991 a 2003, pois existia uma zona de exclusão aérea imposta pelos Estados Unidos com base na Resolução 688/1991 do Conselho de Segurança das Nações Unidas.

${ }^{23}$ As forças espaciais dos Estados Unidos foram criadas no governo Trump em 2018: https://www.defensenews.com/smr/defense-news-conference/2018/09/05/the-top-air-force-official-isnow-onboard-with-trumps-space-force-plan/
} 
espaciais (base de lançamentos de foguetes, satélites, estações espaciais, entre outras). As quatro dimensões geográficas do poder são passíveis de integração.

\subsection{Dimensão Grau de Transição (power shift e power remain)}

O conceito de power shift refere-se à transição e a nova distribuição dos recursos de poder, e não dos resultados políticos consequentes do exercício de poder (da abordagem relacional), pois é difícil auferir quais são os resultados de interesse prioritários de cada ator, para verificação de qual ator tem exercido mais poder nas diversas relações da política internacional.

O power shift relaciona-se com a discussão sobre uma tendência de transição hegemônica do Estados Unidos para a China. Um dos principais recursos de poder fundamentais para um hegemon é a riqueza, a qual é medida pelo Produto Interno Bruto (PIB). A economia chinesa cresce em ritmo muito mais acelerado do que a americana, de modo que o peso relativo do PIB chinês na economia mundial aumente, e o americano diminua. Segundo dados do Fundo Monetário Internacional (FMI) ${ }^{24}$, em 2001, o PIB mundial era de USD 33,59 bilhões, sendo que o PIB do Estados Unidos era USD 10,58 trilhões e o da China de USD 1,34 trilhão. Em 2018, o PIB mundial foi de USD 87,27 trilhões, sendo que PIB do Estados Unidos foi de USD 20,49 trilhões e o da China foi USD 13,41 trilhões. O peso da economia americana na economia mundial era de quase 1/3 em 2001, enquanto em 2018, não chegou a 1/4. Nos anos de 2016, 2017 e 2018 a economia da China cresceu 6,7\%,6,8\% e 6,6\%, respectivamente. Nos mesmos anos, a economia americana cresceu $1,6 \%, 2,2 \%$ e $2,9 \%$, respectivamente.

Outro indicador para análise do power shift são os gastos militares. Segundo dados do Stockholm International Peace Research Institute (SIPRI) ${ }^{25}$, em 2001, os gastos militares dos Estados Unidos foram de USD 432,941 bilhões e os da China foram de USD 49,798 bilhões. Em 2018, os gastos militares dos Estados Unidos foram de USD 633,565 bilhões e os da China foram de USD 239.223 bilhões. Apesar da redução da diferença de gastos com forças armadas entre Estados Unidos e China, ainda em 2018, o peso relativo dos gastos americanos nos gastos mundiais militares ainda era muito significativo,

\footnotetext{
${ }^{24}$ Fonte:

https://www.imf.org/external/datamapper/NGDP_RPCH@WEO/OEMDC/ADVEC/WEOWORLD

${ }^{25}$ Fonte:

https://www.sipri.org/sites/default/files/Data\%20for\%20all\%20countries $\% 20$ from $\% 201988 \%$ E2\%80\%93 2018\%20in $\% 20$ constant $\% 20 \% 282017 \% 29 \% 20$ USD $\% 20 \% 28$ pdf $\% 29$.pdf
} 
atingindo 36\% (mais de 1/3 do total). Logo, o peso relativo do Estados Unidos, em comparação com restante do mundo) é maior nos gastos com forças armadas do que na economia.

No âmbito das instituições também pode-se observar uma tendência inicial de power shift. Stuenkel (2016) observou que, com a participação da China, foram criadas instituições "paralelas" às instituições ocidentais, mas que estão ligadas, em certa medida, em diversas áreas como finanças, segurança, diplomacia e infraestrutura: Novo Banco de Desenvolvimento (NBD), Shanghai Cooperation Organization (SCO), Cúpulas do BRICS, Belt and Road Iniciative (BRI). No entanto, isto não significa haver um esvaziamento total de instituições tradicionais como Banco Mundial (BM), pois a China lá permanece fortalecida, e nem tampouco significa um esvaziamento de organizações que se reforçam em função do fortalecimento chinês, como Organização do Tratado do Atlântico Norte (OTAN) e G7, por exemplo.

Não é em todo recurso de poder que se observa uma transição, e entre os recursos nos quais a transição é observada, as intensidades das mudanças são diferentes. Assim, para complementar o conceito de power shift, propomos o conceito de power remain, que é definido simplesmente pela oposição do conceito de power shift. A China criou novas instituições internacionais (caso de power shift), mas as instituições patrocinadas pelos Estados Unidos continuam muito relevantes, como as do sistema das Nações Unidas e do sistema Bretton Woods (caso de power remain), inclusive com participação mais assertiva da China sob comando de Xi Jinping.

Projeções de transição hegemônica (Nye, 2011) já foram falhas no passado, com superestimação do poder soviético nos anos 1970 e do poder japonês dos anos 1980. As projeções de que a União Soviética e o Japão ultrapassariam o Estados Unidos em recursos de poder não se verificaram.

\subsection{Fungibilidade ou Conversibilidade}

Baldwin (2013) define a ocorrência de fungibilidade (ou conversibilidade) quando um meio de poder (um recurso utilizado) num dado tema é também útil em outros temas. Conforme o referido autor, a fungibilidade liga a dimensão meios do exercício do poder à dimensão escopo.

No presente estudo, ampliaremos a definição de fungibilidade, para não apenas ligar meios ao escopo, mas para ligar meios a qualquer outra dimensão do poder. Por 
exemplo, um meio institucional de exercício do poder (dimensão meios) é capaz de possuir ligação com temas diversos (dimensão escopo), envolvendo vários atores (dimensão domínio), sendo aplicado de maneira soft ou hard (dimensão método de aplicação de meios), com efeitos indiretos (dimensão incidência), limitando a atuação dos atores (dimensão estrutura vs. agência), se enquadrando num contexto de power shift (dimensão grau de transição), contribuindo para a infraestrutura de seus membros (dimensão geográfica), permitindo uma colaboração entre atores no sentido de power with (dimensão grau de dominância), sendo o seu funcionamento mais custoso para uns membros do para outros (dimensão custos) e determinante para o alcance de um resultado (dimensão peso). 


\section{APLICAÇÃO DAS DIMENSÕES DO PODER AO NBD - PARTE I}

Neste capítulo, aplicamos ao Novo Banco de Desenvolvimento as dimensões do poder propostas por Baldwin (2013), quais sejam: meios, escopo, domínio, custos e peso. Para cada dimensão há um tópico próprio com exemplos empíricos que fundamentam as análises.

\subsection{Dimensão Meios de Exercício do Poder}

Numa análise anterior à ação, o poder é visto em razão de potenciais recursos a serem utilizados numa dada relação entre atores. Num estudo a posteriori, o poder é entendido numa perspectiva relacional, na qual dimensões são identificadas, como escopo (tema), domínio (atores), custos, peso e meios (Baldwin, 2013). Os meios são os recursos de fato utilizados para o exercício do poder, isto é, não são apenas potenciais para o uso.

A hipótese do presente estudo é que normas e atos institucionais do NBD constituem um meio de exercício de poder em várias dimensões (isto é, há presença de alta fungibilidade). De acordo com Baldwin (2013), um meio de exercício poder tem alta fungibilidade quando o meio num dado tema também repercute em outros temas. Adaptamos o conceito de modo a fungibilidade significar que um meio de exercício de poder repercute em outras dimensões do poder (como custos, peso, domínio, etc). No presente tópico argumentamos que o NBD é um meio de exercício de poder (devido a normas e atos institucionais). A fungibilidade será analisada nos demais tópicos desta pesquisa.

Para defender que o NBD é meio de exercício de poder é preciso considerar contra-argumentos na análise, não bastando listar colocações favoráveis. Conforme Popper (2007), o papel do(a) cientista não é buscar sistematicamente fatos e argumentos que defendam sua hipótese, muito pelo contrário, ele(ela) deve buscar sistematicamente fatos e argumentos que a derrubem. A ideia de o NBD ser uma instituição eminentemente técnica é o principal contra-argumento em relação à afirmação de que o Banco do BRICS é um meio de exercício de poder (a serviço de interesses políticos).

De acordo com Art, 13 do Acordo Constitutivo:

"O Banco, seus dirigentes e empregados, não poderão interferir nos assuntos políticos de qualquer membro, nem 
ser influenciados nas suas decisões pelo caráter político do membro ou membros em consideração. Apenas considerações econômicas serão relevantes para as suas decisões, e estas considerações serão ponderadas imparcialmente" (destaque nosso).

Em seu documento principal, as atuações do Banco são definidas como marcadas pela imparcialidade, sem interferência em assuntos políticos. Poderíamos refutar tal colocação simplesmente negando a possibilidade da imparcialidade, mas não vamos sistematicamente negar contra-argumentos à nossa hipótese de pesquisa. Vejamos a viabilidade lógica de um agente ser imparcial.

A proposição "a imparcialidade é impossível” é defendida com a seguinte justificativa: "Ninguém consegue adotar um ponto de vista que seja completamente impessoal e desprovido de paixão, completamente separado de qualquer contexto e compromissos particulares" (Young, 2012, p. 178). No entanto, "não podemos investigar o mundo inteiro a fim de determinar que algo não existe, nunca existiu e nunca existirá" (Popper, 2007, p. 73). Em outras palavras, não há como saber se o tempo todo e em todos os lugares, as pessoas não estão agindo de maneira impessoal. Com base na proposição de Popper (2007), depreende-se da colocação de Young (2012) uma afirmativa muito forte acerca da impossibilidade da imparcialidade, a de que as pessoas são parciais o tempo todo e em todos os lugares. Trata-se de uma ideia muito questionável.

Além disso, mesmo se assumíssemos como verdade a impossibilidade de ser imparcial, é razoável supor a existência de diferentes graus de parcialidade. De modo que aqueles pouco parciais pudessem ser considerados imparciais. Dependeria do caso concreto o entendimento acerca do que seria "muito" ou "pouco" parcial.

Rebatemos o contra-argumento da imparcialidade, não alegando a sua impossibilidade, mas sim, questionando a sua frequência. O Banco realiza atos técnicos (não políticos) no desempenho de suas funções, entretanto, isso não implica que todas as suas atividades e todos os significados de sua criação sejam imparciais. Ademais, quando há mais de uma maneira de se atuar tecnicamente, a escolha da técnica pode ser permeada por interesses políticos. Existindo já 21 bancos multilaterais de desenvolvimento (BMD), por que criar mais $u^{26}$ ? Não sendo a sustentabilidade a única forma de um país se

\footnotetext{
${ }^{26}$ Suchodolski (2018) lista 23 BMD, incluindo o NBD e o AIIB. Como o AIIB é posterior ao NBD, antes da criação do NBD já existiam 21 BMD.
} 
desenvolver, por que criar um BMD com discurso voltado ao desenvolvimento sustentável? Não bastando a realização de construções para um país se desenvolver, por que criar um BMD com foco na infraestrutura? Uma resposta que permeia as três questões é: são opções políticas, muito provavelmente ligadas à ideia de poder. Depreende-se da visão de vários autores que o poder é o principal conceito da política (Aristóteles, 2012; Weber, 1947; Dahl, 1957; Bobbio, 2004).

Conforme Stuenkel (2017b), criar, liderar e controlar instituições internacionais é um meio de influenciar outros atores. Da mesma forma que potências ocidentais utilizaram instituições internacionais, como o Banco Mundial e o FMI, para projetar os seus poderes e atrair países para a suas esferas de influência, a China e outras potências não-ocidentais utilizam as suas novas instituições para semear uma nova centralidade, criando laços com as economias de diferentes países, e eventualmente gerando uma forte influência política.

Por um lado, instituições (Stuenkel, 2017b) proporcionam bens públicos; por outro, são veículos de projeção de influência. É difícil separar os dois lados. A liderança em instituições, como um banco de desenvolvimento, inevitavelmente confere poder político. Participar de instituições lideradas pelos Estados Unidos e de instituições lideradas pela China, pode prover ao Brasil e à Índia, por exemplo, uma flexibilidade e uma margem de manobra que aumentam os seus poderes de barganha nas referidas estruturas institucionais.

Segundo Abdenur (2014), a iniciativa do NBD faz parte dos esforços de pressão para uma reforma da governança global na área do desenvolvimento, buscando prover uma instituição multilateral que possa oferecer para países em desenvolvimento acesso à capital para projetos de infraestrutura e industrialização. Com o Banco, o BRICS pode exercer pressão sobre instituições existentes, no sentido de realização de reformas, ao mesmo tempo que apresenta uma alternativa concreta ao sistema Bretton Woods. Além disso, o Banco legitima o agrupamento ao evidenciar a capacidade de lançamento de iniciativas concretas.

No entanto, mesmo visualizando o contexto internacional sob a ótica da transição hegemônica entre Estados Unidos e China, pode-se observar elementos do Banco do BRICS que não sinalizam um power shift, mas sim um power remain. Em outras palavras, há alguns fatores do NBD que não desafiam a hegemonia norte-americana, como a utilização do dólar americano nos financiamentos de projetos do Banco. Trata-se de uma questão a ser analisada no tópico "grau de transição do poder". 
O NBD é um meio institucional de exercício de poder porque é possível utilizá-lo tanto para punir membros (com suspensão ou inabilitação ${ }^{27}$ ), como para atrair e persuadir a adesão de novos membros, por meio da divulgação de fatos e argumentos acerca de suas propostas e realizações. No tópico "dimensão método de aplicação de meios", veremos que a punição é ligada ao hard power, e a atração e a persuasão são ligadas ao soft power, conforme definição de Nye (2011). A instituição em tela permite a prática de métodos tanto hard como soft, além da combinação de ambos.

A existência de uma estrutura institucional no Banco do BRICS tanto limita ações de seus membros como abre possibilidades de atos diversos. Nesse sentido, observa-se a coexistência de um poder estrutural e de um poder de agência. No tópico "dimensão agência vs. estrutura" veremos as dinâmicas que envolvem a estrutura e os atores, quais sejam, os membros da instituição. Ademais, as manutenções da máquina institucional e de suas atividades e projetos acarretam custos, os quais podem abranger um percentual maior da economia de alguns membros em relação a outros. Os montantes dos recursos destinados por cada integrante para a manutenção do Banco, bem como os seus respectivos percentuais em relação a cada $\mathrm{PIB}$, serão abordados no tópico "dimensão custos do poder".

Numa instituição é comum a existência de relações tanto de dominação e resistência, como relações de atuação conjunta horizontal. Três conceitos descrevem tais interações, quais sejam, power-over, power-to e power-with (Berger, 2005), respectivamente. No NBD não é diferente. As aplicações e as limitações dos referidos conceitos serão abordadas no tópico "grau de dominância do poder". Além disso, decisões são tomadas no âmbito do Banco do BRICS, nas quais é possível analisar em que medida determinada decisão pode ter sido mais influenciada pelo poder de um membro específico. É um assunto a ser tratado no tópico "peso do poder".

Um banco de desenvolvimento que se proponha ao financiamento de obras de infraestrutura, inegavelmente, transforma o espaço geográfico dos países membros, bem como possui o potencial de contribuir para o poder terrestre, marítimo e aéreo dos mesmos. Como este é o caso do NBD, abordaremos os potenciais impactos dos projetos de infraestrutura no tópico "dimensão geográfica do poder". No entanto, há que se ressaltar que os referidos impactos tendem a não serem imediatos, de maneira que a incidência das obras não seja direta. Trata-se de um ponto a ser explorado no tópico

\footnotetext{
${ }^{27}$ BRICS. Acordo Constitutivo sobre o Novo Banco de Desenvolvimento. 2014.
} 
“dimensão incidência do poder", o qual tem por base os conceitos de incidência direta e indireta de Barnett e Duvall (2005).

No âmbito de uma instituição, temas diferentes são abordados. No caso do NBD, a infraestrutura e o desenvolvimento sustentável são dois que se destacam, como será analisado no tópico "escopo do poder". Relações de poder com a participação de uma instituição envolve não apenas temas diversos, mas também atores variados. Os agentes envolvidos, em maior ou menor grau, nas relações de poder do Banco do BRICS serão abordados no tópico "domínio do poder".

A hipótese que normas e atos institucionais do NBD constituem um meio de exercício de poder, como repercussões em outras dimensões, não exclui outras possíveis hipóteses que analisem o referido Banco através da ótica de outros conceitos, como o de cooperação, por exemplo. Inclusive, esta é uma limitação do presente estudo, a não refutação de toda e qualquer hipótese rival. A única hipótese alternativa afastada é a de que o NBD seria uma instituição predominantemente técnica, sem ressonâncias políticas diversas. Conforme breves explicações acima juntamente com explanações mais detalhadas ao longo da presente pesquisa, o Banco do BRICS emana poder em diversos aspectos, não sendo um instrumento somente técnico para os seus membros ${ }^{28}$.

\subsection{Dimensão Escopo do Poder}

O escopo (Baldwin, 2013) trata do tema no qual ocorre uma relação de poder. $\mathrm{O}$ Novo Banco de Desenvolvimento envolve relações de poder em vários temas, como instituições, economia e desenvolvimento. O tema instituições será abordado em outras partes deste estudo, como no tópico "dimensão grau de transição do poder" e no tópico “dimensão agência vs. estrutura". O tema economia também será abordado em outras partes desta pesquisa, como no tópico “dimensão custos do poder" e no tópico "dimensão peso do poder". Assim, o foco do presente tópico é a abordagem do tema desenvolvimento, o qual é relevante para a análise de um banco multilateral que se propõe a ter as suas atividades voltadas para a referido tema.

Os membros do BRICS, por meio do NBD, contribuem para uma determinada perspectiva acerca do conceito de desenvolvimento, fortemente ligada às ideias de infraestrutura e sustentabilidade. Expressamente no Acordo Constitutivo sobre o Novo

\footnotetext{
${ }^{28}$ Pode-se questionar inclusive se algum banco pode ser considerado essencialmente técnico.
} 
Banco de Desenvolvimento ${ }^{29}$, os integrantes do BRICS reconhecem a relevância do fornecimento de recursos para projetos de infraestrutura e desenvolvimento sustentável, tanto para os países membros como para outros países em desenvolvimento, sendo tal financiamento um dos objetivos da instituição.

O NBD firmou um memorando de entendimento com o Ministério de Finanças da China, no âmbito da Belt and Road Initiative. A análise contextual de tal documento é útil para a compreensão do conceito de desenvolvimento do Banco do BRICS, pois o referido memorando possui como foco a infraestrutura e a sustentabilidade.

O Memorandum of Understanding on Collaboration on Matters of Common Interest Under the Belt and Road Initiative ${ }^{30}$ objetiva as seguintes ações: o aumento do apoio aos projetos de infraestrutura e conectividade; o fortalecimento da coordenação e da capacidade de construção; a criação de mecanismos diversificados e estáveis de financiamento ao desenvolvimento sustentável; a melhoria do business climate; o apoio para a Agenda 2030 das Nações Unidas para o desenvolvimento sustentável, com o alcance dos Objetivos do Desenvolvimento Sutentável (ODSs) e do Acordo de Paris sobre Mudança Climática.

Dois dos cinco objetivos do referido memorando referem-se especificamente a construção e a infraestrutura. Os outros três objetivos possuem vínculos ou foco direto com o desenvolvimento sustentável, tendo por base os ODSs. Comecemos pelo elemento sustentabilidade. Por meio de uma breve análise contexto internacional é possível observar que a visão de desenvolvimento sustentável do NBD é em parte aproximada da perspectiva das Nações Unidas.

No âmbito das Nações Unidas, em 1982, foi criada a Comissão Mundial sobre o Meio Ambiente e Desenvolvimento, presidida pela então Primeira-Ministra da Noruega Gro Harlem Brundtland. Em 1987, a Comissão divulgou o Relatório Our Common Future, também conhecido como Relatório Brundtland (Romeiro, 2012). O referido Relatório define desenvolvimento sustentável da seguinte forma: "Humanity has the ability to make development sustainable to ensure that it meets the needs of the present without compromising the ability of future generations to meet their own needs" ${ }^{31}$ (p.16).

\footnotetext{
${ }^{29}$ BRICS. Acordo Constitutivo sobre o Novo Banco de Desenvolvimento. 2014.

30 https://www.ndb.int/wp-content/uploads/2018/09/MOU-on-BRI-signed.pdf Acesso: 20/03/2019, às 00h18.

31 Disponível em: https://sustainabledevelopment.un.org/content/documents/5987our-common-future.pdf Acesso: 22/06/2019, às 16h20.
} 
A Resolução A/RES/70/1 ${ }^{32}$, adotada pela Assembleia Geral das Nações Unidas em 25/09/2015, é o documento que estabelece a Agenda 2030, com 17 objetivos para o desenvolvimento sustentável (ODS), isto é, para o atendimento das necessidades da geração atual sem comprometer as gerações futuras. Os 17 objetivos são: 1) Erradicação da Pobreza; 2) Fome Zero; 3) Saúde e Bem-Estar; 4) Educação de Qualidade; 5) Igualdade de Gênero; 6) Água Limpa e Saneamento; 7) Energia Limpa e Acessível; 8) Trabalho Decente e Crescimento Econômico; 9) Indústria, Inovação e Infraestrutura; 10) Redução da Desigualdades; 11) Cidades e Comunidades Sustentáveis; 12) Consumo e Produção Responsáveis; 13) Ação contra as mudanças climáticas; 14) Vida Aquática; 15) Vida Terrestre; 16) Paz, Justiça e Instituições Inclusivas; 17) Parcerias para Implementação dos Objetivos.

As próprias atividades do Banco do BRICS podem ser interpretadas como resposta ao $17^{\circ}$ ODS (Parcerias para Implementação dos Objetivos), uma vez que existem demandas para financiamentos diversos ${ }^{33}$. Assim, percebe-se que a criação da instituição está conectada à agenda global e leva em consideração os diálogos nas Nações Unidas. Ademais, o sítio oficial do Novo Banco de Desenvolvimento ${ }^{34}$ categoriza os projetos em seis setores: Energia Limpa; Transporte; Infraestrutura Social; Infraestrutura Urbana; Proteção Ambiental; Água, Saneamento e Proteção contra Inundações. Cada um dos setores apresenta alguma aproximação com pelo menos um ODS. O setor Energia Limpa é quase coincidente com o $7^{\circ}$ ODS (Energia Limpa e Acessível). Os setores Transporte, Infraestrutura Social e Infraestrutura Urbana possuem proximidade com o $9^{\circ}$ ODS (Indústria, Inovação e Infraestrutura) e com o $11^{\circ}$ ODS (Cidades e Comunidades Sustentáveis). O setor Proteção Ambiental possui proximidade com o $13^{\circ}$ ODS (Ação contra as mudanças climáticas), com o $14^{\circ}$ ODS (Vida Aquática) e com o $15^{\circ}$ ODS (Vida Terrestre). O setor Água, Saneamento e Proteção contra Inundações é quase coincidente com o $6^{\circ}$ ODS (Água Limpa e Saneamento).

Dos 37 projetos aprovados até 31/05/2019, 14 se enquadram no setor Energia Limpa, sendo seis propostos pela China, três pela Índia, três pela África do Sul, um pelo

\footnotetext{
32 Disponível em: https://www.un.org/ga/search/view doc.asp?symbol=A/RES/70/1\&Lang=E Acesso: $22 / 06 / 2019$, às 16 h46.

${ }^{33}$ Conforme o Report of the Secretary-General on SDG Progress 2019 (Special Edition), as estimativas dos valores necessários para o atingimento dos Objetivos do Desenvolvimento Sutentável variam em escala dos bilhões ao trilhões de dólares. Por exemplo, os financiamentos necessários para suprir os gaps de infraestrutura com relação à água, saneamento, energia, irrigação e proteção contra inundações pode variar de $2 \%$ a $8 \%$ do PIB, por ano até 2030 , dependendo das escolhas políticas feitas por cada país.

${ }^{34} \mathrm{https}$ ://www.ndb.int/projects/list-of-all-projects/ Acesso: 31/05/2019, às $21 \mathrm{~h} 01$.
} 
Brasil e um pela Rússia. O setor Transporte possui 10 projetos propostos até a mesma data, sendo cinco apresentados pela Índia, dois pela China, um pelo Brasil, um pela Rússia e um pela África do Sul. O setor Infraestrutura Social contém oito projetos apresentados até a mesma data, sendo três propostos pelo Brasil, dois pela China, um pela Rússia, um pela Índia e um pela África do Sul. O setor Infraestrutura Urbana só possui um projeto, apresentado pela Rússia. O setor Proteção Ambiental contém dois projetos, um proposto pela Rússia e um pela África do Sul. O setor Água, Saneamento e Proteção contra Inundações possui dois projetos, um apresentado pela Rússia e um pela China.

Pela categorização do sítio oficial do NBD, não há sobreposição de setores, isto é, cada projeto se enquadra em apenas um setor alvo. Apenas dois setores (Energia Limpa e Transporte) compreendem 64,8\% dos projetos do NBD aprovados até o fim de maio de 2019, de modo que a contribuição para os ODSs não seja tão distribuída entre os objetivos passíveis de receberem colaboração através dos projetos do Banco.

Há outras formas que o NBD pode contribuir com os ODS, mesmo fora do âmbito dos projetos. Por exemplo, o $5^{\circ}$ ODS (Igualdade de Gênero) poderia ser levado em consideração na quantidade de Diretores, Governadores e funcionários do Banco. Segundo o Relatório Anual do NBD de 2017²5, em 2016 o Banco possuía 68 funcionários (staff), sendo 37 homens e 21 mulheres. Conforme o mesmo Relatório, o Banco passou a ter 106 funcionários em dezembro de 2017, com 63 homens e 43 mulheres. O percentual de mulheres aumentou de 30,8\% em 2016 para 40,5\% em 2017. Quanto aos funcionários, o NBD está se aproximando da igualdade de gênero, mas o mesmo não se verifica nos cargos de tomadores de decisão, ou seja, os membros do Conselho de Governadores e do Conselho de Diretores.

No ano de 2016, entre os cinco governadores e entre os cinco diretores não havia nenhuma mulher ${ }^{36}$. No ano de 2019 (junho), entre os cinco governadores, havia apenas uma mulher, a senhora Nirmala Sitharaman (Ministra de Finanças da Índia). Entre os suplentes do Conselho de Governadores, também havia apenas uma mulher, a senhora Jiayi Zou (Vice-Ministra de Finanças da China). Em 2019 (junho), entre os cinco diretores, não havia nenhuma mulher. Entre os suplentes do Conselho de Diretores, havia

\footnotetext{
35 Disponível em: https://www.ndb.int/wp-content/uploads/2018/07/NDB AR2017.pdf Acesso: 05/06/2019, às $18 \mathrm{~h} 30$.

${ }^{36}$ Fonte: Relatório Anual do NBD de 2017. Em 2016, os cinco governadores eram: Henrique de Campos Meirelles (Brasil), Anton Siluanov (Rússia), Arun Jaitley (Índia), Jie Xiao (China) e Malusi Gigaba (África do Sul).
} 
apenas uma mulher, a senhora Vuyelwa Vumendlini (Deputy Director-General for International and Regional Economic Policy, National Treasury da África do Sul) ${ }^{37}$.

\subsubsection{Comparação com a Belt and Road Initiative}

Apesar da possibilidade de maiores avanços por parte do NBD para o alcance dos ODS, de maneira geral, o Banco não destoa da visão de desenvolvimento sustentável proposta pela Nações Unidas. Além da sustentabilidade, a infraestrutura é marcante na perspectiva do NBD acerca do desenvolvimento. Conforme o memorando de entendimento supracitado, vale uma análise comparativa com a Belt and Road Initiative.

Infraestrutura também é o cerne da Belt and Road Initiative, proposta por $\mathrm{Xi}$ Jinping em 2013. Trata-se de uma rede de infraestrutura que conecta a Ásia, a Europa e a África, por meio da Silk Road Economic Belt e da 21st. Century Maritime Silk Road ${ }^{38}$, envolvendo a construção de rodovias, ferrovias, malhas energéticas, oleodutos, gasodutos, portos, aeroportos, sistemas de fibra-óptica e comunicações. É uma política para as rotas de comércio da China, visando maior crescimento econômico e impactos geopolíticos, contanto com financiamento de banco multilaterais de desenvolvimento como o AIIB e o NBD (Yeh, 2016; Blanchard e Flint, 2017; Zhang, Alon e Lattermann, 2018).

A 21st. Century Maritime Silk Road (Blanchard e Flint, 2017) se inicia na cidade chinesa de Fuzhou (na província de Fujian), chegando ao Sudeste Asiático através do Mar do Sul da China, para então, alcançar o Oceano Índico via o estreito de Malacca (entre a Ilha de Sumatra e a Península Malaia). Pelo Oceano Índico, a Rota atinge os países no Oeste da África, para seguir na direção do Mar Mediterrâneo, via Canal de Suez. A Silk Road Economic Belt busca aproximar a China da Ásia Central, da Rússia e da Europa (até o Báltico), ligando também a China ao Golfo Pérsico, ao Mar Mediterrâneo, ao Sudeste da Ásia e ao Oceano Índico, envolvendo países como Cazaquistão, Uzbequistão,

\footnotetext{
${ }^{37}$ Fonte: https://www.ndb.int/about-us/organisation/governance/ Acesso: 23/06/2019, às 19h50. Em 2019 (junho), os cinco governadores eram: Paulo Guedes (Brasil), Anton Siluanov (Rússia), Nirmala Sitharaman (Índia), Kun Liu (China) e Tito Titus Mboweni (África do Sul). Os suplentes do Conselho de Governadores eram: Roberto Campos Neto (Brasil), Subhash Chandra Garg (Índia), Jiayi Zou (China), Mondli Gungubele (África do Sul). Obs.: Na data acessada, o sítio do NBD não indicava suplente russo. Em 2019 (junho), os cinco diretores eram: Marcos Troyjo (Brasil), Sergei Storchak (Rússia), K Rajaraman (Índia), Wencai Zhang (China), Enoch Godongwana (África do Sul). Os suplentes do Conselho de Diretores eram: Tiago Couto Berriel (Brasil), Andrey Bokarev (Rússia), Prashant Goyal (Índia), Zhengwei Zhang (China) e Vuyelwa Vumendlini (África do Sul).

${ }^{38}$ Belt and Road Portal: https://eng.yidaiyilu.gov.cn/qwyw/rdxw/1046.htm Acesso: 19/03/2019, às 10h31.
} 
Quirguistão, Turcomenistão, Tajiquistão, Rússia, Mongólia, Índia, Paquistão, Afeganistão, Irã e Turquia.

Acompanhando a infraestrutura, o empreendimento da Belt and Road Initiative requer complementação com a assinatura de acordos sobre investimentos e comércio (Blanchard e Flint, 2017). Para o referido projeto chinês alcançar todo o seu potencial, os países envolvidos precisam concluir ou complementar acordos de livre comércio (para remoção de barreiras na troca de bens), negociar acordos de investimentos (liberalizando setores para investimento estrangeiro), o que passa pelo estabelecimento ou reforço de instituições financeiras.

Nesse sentido, o Banco do BRICS, que possui como objetivo financiamentos de projetos de infraestrutura, apresenta uma perspectiva sobre o conceito de desenvolvimento aproximada da ideia de infraestrutura utilizada para as rotas de comércio chinesas. De certa forma, assim como a China (por meio da Belt and Road Initiative), os membros do BRICS (por meio do NBD) também buscam atrair novos atores para as suas relações de poder através da infraestrutura e dos arranjos institucionais que os acompanhem ${ }^{39}$.

Vários dados que apontam a enorme demanda por investimentos em infraestrutura no mundo em desenvolvimento (Suchodolski e Demeulemeester, 2018). De acordo com o relatório do Fórum Econômico Mundial sobre infraestrutura ${ }^{40}$, existem 1,6 bilhão de pessoas sem acesso à eletricidade, 884 milhões de pessoas sem suprimento de água potável, e 2,5 bilhões de pessoas sem acesso ao saneamento básico. Ainda segundo o mesmo relatório, a demanda por investimentos em infraestrutura é de 4 trilhões de dólares por ano, enquanto a oferta é de 1 trilhão de dólares.

Sem dúvida, o alcance do desenvolvimento passa por investimentos em infraestrutura. No entanto, o desenvolvimento não se atinge somente com infraestrutura, mas também com investimentos em serviços de educação, saúde, segurança, incluindo a capacitação de profissionais e a aquisição de materiais, como livros, medicamentos, computadores e outros itens diversos. Logo, foi uma opção política a criação de um banco de desenvolvimento com foco na infraestrutura (a qual também é necessária para as outras áreas do desenvolvimento, como educação, saúde e segurança, mas não é suficiente). Por

\footnotetext{
39 Segundo Baldwin (2013), a quantidade de atores envolvidos numa relação de poder é definida pela dimensão "domínio do poder". A presente pesquisa possui um tópico próprio que aborda tal dimensão.

${ }^{40} \mathrm{WEF}$ (2013) Strategic Infrastructure: Steps to Prepare and Accelerate Public-Private Partnerships. May 2013. Geneva: World Economic Forum.
} 
exemplo, o Programa das Nações Unidas para o Desenvolvimento (PNUD) preocupa-se não apenas com infraestrutura, mas também com a erradicação da pobreza, a melhoria da saúde, o empoderamento das mulheres, a pacificação de regiões em conflito, entre outras áreas ${ }^{41}$.

Conforme (Wendt, 1999), o poder na política internacional é constituído em importante parte pela distribuição dos interesses, que por sua vez é constituída em importante parte por ideias. Poder e interesses têm seus efeitos devido às ideias que os constituem. Ideias não são mais importantes do que poder e interesses, nem autônomas em relação ao poder e aos interesses.

Portanto, o tema central da instituição NBD é manifestado por uma ideia (uma shared view) sobre o conceito de desenvolvimento focado na infraestrutura e na sustentabilidade, de modo a atender interesses de desenvolvimento nacional, bem como propiciar o exercício e o aumento de recursos de poder. A infraestrutura é útil para trazer novos atores para as relações de poder (como veremos no tópico "dimensão domínio do poder") e para reforçar recursos de poder (como veremos no tópico “dimensão geográfica do poder"). A sustentabilidade serve como a atração típica do soft power (como veremos no tópico "dimensão método de aplicação de meios de poder").

\subsection{Dimensão Domínio do Poder}

A dimensão domínio do poder trata da quantidade de atores envolvidos numa relação de poder (Baldwin, 2013). No caso do Novo Banco de Desenvolvimento, além dos cinco membros do BRICS, podem-se identificar cenários com o potencial envolvimento de diversos outros atores, além da possibilidade de adesão de qualquer integrante das Nações Unidas, permitida pelo Acordo Constitutivo do Banco ${ }^{42}$.

A dimensão domínio do poder para o NBD pode ser entendida por meio do conceito de BRICS+Circle. Trata-se de uma ideia criada pelo Ministro das Relações Exteriores da China Wang Yi e desenvolvida posteriormente por Lissovolik (2017). Durante a conferência de impressa do Meeting of BRICS Ministers of Foreign Affairs realizada em 19/06/2017, Wang Yi disse:

\footnotetext{
${ }^{41}$ UNDP Strategic Plan, 2018-2021. Disponível em: http://undocs.org/DP/2017/38 Acesso: 19/03/2019, às $22 \mathrm{~h} 30$.

${ }^{42}$ BRICS. Acordo sobre o Novo Banco de Desenvolvimento. 2014. Art. $2^{\circ}$.
} 
"The BRICS countries not only pertain to these five countries, but also to all emerging market countries and developing countries. We will continue to uphold the BRICS spirit of openness, inclusiveness and cooperation and win-win results and advocate the mutual inclusiveness among different systems and cultures. We will continue to develop a cooperation model featuring mutual benefits and win-win outcomes, and continuously expand circle of friends and increase the number of beneficiaries of BRICS cooperation [...]. China will continue to strengthen and enrich the three cooperation pillars based on consensus through consultation, actively develop more cooperation in emerging fields and expand the 'BRICS+' model of dialogue and cooperation"43 (destaque nosso).

Como Wang Yi é um diplomata experiente, ele não utilizaria o termo “domínio", como o elaborado por Baldwin (2013), para se referir à expansão do número de atores envolvidos nas relações de poder do BRICS. Wang Yi preferiu usar repetidas vezes a palavra "cooperação", a qual vai ao encontro do lema da política externa chinesa, "Peaceful Rising". Além disso, no discurso do Ministro das Relações Exteriores da China há presença das ideias de diálogo, consenso, inclusividade, abertura, benefícios mútuos e resultados de "ganha-ganha". Depreende-se do emprego dos referidos termos que o BRICS seria, de certa forma, representante dos países em desenvolvimento e que possui interesse numa maior participação desses países, na sua atuação política internacional. As expressões "BRICS+" e "circle of friends" sintetizam o interesse que mais países em desenvolvimento participem das políticas do BRICS.

Segundo Lissovolik (2017), o BRICS pode exercer a função de plataforma de agregação para diversos tipos de acordo, incluindo de comércio e investimentos, aumentando o diálogo entre países em desenvolvimento. O referido autor define tal plataforma pela expressão BRICS+Circle, utilizando a ideia criada por Wang Yi. Tratase da potencial capilaridade da esfera de influência do BRICS, proporcionada pelas

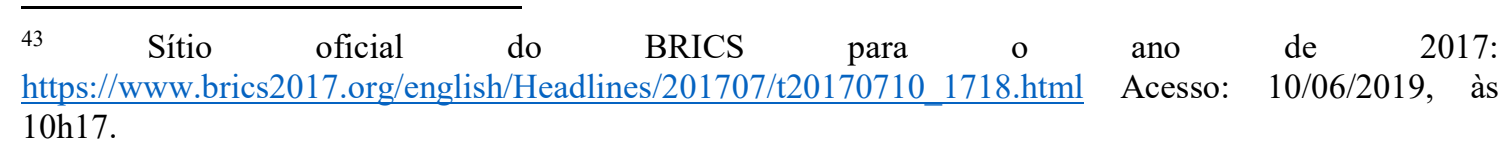


posições de destaque que seus membros ocupam em organizações regionais: Brasil no Mercado Comum do Sul (Mercosul), Rússia na Eurasian Economic Union (EEU), Índia na South Asian Association for Regional Cooperation (SAARC), China na Shanghai Cooperation Organisation (SCO) bem como no FTA China-Association of Southeast Asian Nations (Asean), e África do Sul na South African Development Community (SADC). Considerando todas as organizações somam-se 35 países $^{44}$. Montenegro e Mesquita (2017) realçaram o papel do Brasil na União de Nações Sul-Americanas (Unasul) ${ }^{45}$ e da Rússia na Comunidade de Estados Independentes (CEI). Neste caso, o número de países somados sobe para 48 ao todo ${ }^{46}$.

A plataforma BRICS+Circle (Lissovolik, 2017) pode servir de base para iniciativas intercontinentais, como acordos entre dois dos blocos regionais acima, ou acordos bilaterais entre países de blocos distintos, ou ainda acordos entre um bloco e um país terceiro. A expansão de tal rede institucional permite não apenas aumentar as perspectivas de integração, como também aumentar as opções de modelos integração dos países, quanto a gradação e número de atores relacionados, sem a restrição do regionalismo e sem a busca por um bloco unificador.

Um exemplo prático e inicial do BRICS+Circle ocorreu em 2016 (Lissovolik, 2017), quando a Índia convidou os demais membros da Bay of Bengal Initiative for MultiSectoral Technical and Economic Cooperation (BIMSTEC) ${ }^{47}$ para participarem de uma reunião com os membros do BRICS. A BIMSTEC é um acordo regional de livrecomércio que inclui Índia, Bangladesh, Butão, Myanmar, Nepal, Tailândia e Sri Lanka. A BISMSTEC é uma outra opção para a Índia operar o BRICS+Circle além da SAARC.

Também por meio do NBD, o BRICS+Circle vem operando através de acordos diversos firmados com outras instituições internacionais ligadas ao tema do

\footnotetext{
${ }^{44}$ Mercosul (incluindo membro em processo de adesão): Brasil, Argentina, Paraguai, Uruguai, Bolívia e Venezuela.

EEU: Rússia, Cazaquistão, Bielorrússia, Armênia e Quirguizistão;

SAARC: Índia, Afeganistão, Bangladesh, Butão, Maldivas, Nepal, Paquistão e Sri Lanka;

FTA China-ASEAN: China, Indonésia, Malásia, Filipinas, Singapura, Tailândia, Brunei, Vietnã, Laos, Myanmar e Camboja;

SACU: África do Sul, Botsuana, Lesoto, Namíbia e Suazilândia.

${ }^{45}$ Com o esvaziamento da UNASUL, em 2019 foi criado o Foro para o Progresso e Integração da América do Sul - PROSUL (Brasil, Argentina, Chile, Colômbia, Equador, Peru e Paraguai): http://www.itamaraty.gov.br/pt-BR/politica-externa/integracao-regional/688-prosul Acesso: 19/10/2019, às $19 \mathrm{~h} 40$.

${ }^{46}$ Os 35 listados acima, mais os membros da Unasul que não estão no Mercosul (Chile, Colômbia, Equador, Guiana, Peru e Suriname) e os membros da CEI que não estão na EEU (Azerbaijão, Geórgia, Moldávia, Turcomenistão, Tajiquistão, Ucrânia e Uzbequistão).

${ }^{47}$ https://bimstec.org/ Acesso: 19/10/2019, às 19h40.
} 
desenvolvimento, nas quais os membros do BRICS fazem parte. Até 31/05/2019, o NBD firmou 10 memorandos de entendimento com 14 diferentes entidades internacionais ${ }^{48}$, quais sejam: Financial Fund for the Development of the River Plate Basin $(\text { FONPLATA })^{49}$, Corporación Andina de Fomento ${ }^{50}$, Inter-American Development Bank $^{51}$, Inter-American Investment Corporation ${ }^{52}$, Eurasian Development Bank ${ }^{53}$, European Bank for Reconstruction and Development ${ }^{54}$, European Investment Bank ${ }^{55}$, International Investment Bank ${ }^{56}$, Asian Infrastructure Investment Bank ${ }^{57}$, International Bank for Reconstruction and Development ${ }^{58}$, International Development Association ${ }^{59}$, International Finance Corporation ${ }^{60}$, Multilateral Investment Guarantee Agency ${ }^{61} \mathrm{e}$ Asian Development Bank ${ }^{62}$.

O International Bank for Reconstruction and Development ${ }^{63}$ é um banco multilateral de desenvolvimento criado em 1944 para ajudar na reconstrução da Europa, e posteriormente teve o seu foco voltado para a redução da pobreza nos países em desenvolvimento (conta com 189 países membros). O International Development Association $^{64}$ é uma instituição que visa a redução da pobreza por meio de empréstimos e subvenções para programas de reforço ao crescimento econômico (conta com 173

\footnotetext{
${ }^{48}$ Fonte: https://www.ndb.int/partnerships/agreements-memoranda/ Acesso: 13/06/2019 às 21h41. Obs.: Ao todo, o NBD firmou 14 memorandos de entendimento até 31/05/2019. Dos quatro não listados acima, três foram firmados com bancos nacionais dos países membros do BRICS, e um foi firmado com o Ministério das Finanças da China.

49 https://www.ndb.int/wp-content/uploads/2017/05/MOU-with-FONPLATAApril-2017.pdf Acesso: $13 / 06 / 2019$ às $21 \mathrm{~h} 45$.

${ }^{50} \mathrm{https://www.ndb.int/wp-content/uploads/2017/01/MOU-NDB-CAF.pdf} \mathrm{Acesso:} \mathrm{13/06/2019} \mathrm{às} 21 \mathrm{~h} 46$.

${ }_{51}$ https://www.ndb.int/wp-content/uploads/2018/09/MOU-with-IDB-IDB-Invest-signed.pdf Acesso: $13 / 06 / 2019$ às $21 \mathrm{~h} 48$.

52 Idem.

53 https://www.ndb.int/wp-content/uploads/2017/04/MOU-with-EDBApril-2017.pdf Acesso: 13/06/2019 às $21 \mathrm{~h} 50$.

$54 \quad$ https://www.ndb.int/wp-content/uploads/2017/04/MOU-with-EBRDApril-2017.pdf Acesso: $13 / 06 / 2019$, às $21 \mathrm{~h} 51$.

55 https://www.ndb.int/wp-content/uploads/2017/04/MOU-with-EIBApril-2017.pdf Acesso: 13/06/2019, às $22 \mathrm{~h} 25$.

${ }^{56} \mathrm{https}$ ://www.ndb.int/wp-content/uploads/2017/04/MOU-with-IIBArpil-2017.pdf Acesso: 13/06/2019, às $21 \mathrm{~h} 56$.

57 https://www.ndb.int/wp-content/uploads/2017/04/MOU-with-AIIBApril-2017.pdf Acesso: 20/03/2019 às $00 \mathrm{~h} 24$.

${ }^{58} \mathrm{https}$ ://www.ndb.int/wp-content/uploads/2017/01/MOU-NDB-WBG.pdf Acesso: 13/06/2019, às $22 \mathrm{~h} 01$.

59 Idem.

${ }^{60}$ Idem.

${ }^{61}$ Idem.

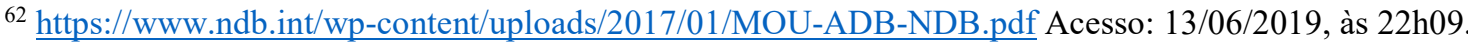

$63 \mathrm{https}$ ://www.worldbank.org/en/who-we-are/ibrd Acesso: 17/06/2019, às 20h13.

${ }^{64} \mathrm{http}$ ://ida.worldbank.org/ Acesso: 17/06/2019, às $20 \mathrm{~h} 25$.
} 
membros). O International Finance Corporation ${ }^{65}$ é um instituição com atuação global e que foca exclusivamente no setor privado dos países em desenvolvimento. O Multilateral Investment Guarantee Agency ${ }^{66}$ é uma instituição que promove investimentos transfronteiriços em países em desenvolvimento, fornecendo garantias a investidores e credores. As quatro instituições fazem parte do Grupo Banco Mundial. O memorando de entendimento entre o NBD e as quatro instituições citadas ${ }^{67}$ objetiva ações como: a exploração de oportunidades de co-financiamento de projetos; a exploração de oportunidades de cooperação no gerenciamento do tesouro; a troca de conhecimento a respeito das operações, levando em consideração as respectivas políticas e procedimentos.

O FONPLATA ${ }^{68}$ é uma instituição financeira multilateral que visa financiar estudos, projetos e programas com o objetivo de fomentar o desenvolvimento e a integração entre os seus cinco membros, quais sejam, Brasil, Argentina, Bolívia, Paraguai e Uruguai. O memorando de entendimento entre o NBD e o FONPLATA ${ }^{69}$ objetiva ações como: a troca de informações nas áreas de infraestrutura, energia e meio ambiente; a realização de pesquisas que promovam o compartilhamento de conhecimento institucional; o co-financiamento de projetos de desenvolvimento de interesse mútuo; a troca de recursos humanos, como pesquisadores e experts, para suporte de projetos de interesse comum.

A Corporación Andina de Fomento ${ }^{70}$ é uma instituição financeira multilateral que mobiliza recursos para serem aplicados aos setores público e privado de seus países membros. São mais de 15 países integrantes da referida organização, incluindo o Brasil, embora fossem apenas seis os membros fundadores: Bolívia, Chile, Colômbia, Equador, Peru e Venezuela. O memorando de entendimento entre o NBD e a Corporación Andina de Fomento $^{71}$ objetiva ações como: a troca de informações nas áreas de infraestrutura, energia e meio ambiente; a realização de pesquisas que promovam o compartilhamento de conhecimento institucional; o co-financiamento de projetos de desenvolvimento de

65 https://www.ifc.org/wps/wcm/connect/corp ext content/ifc external corporate site/home Acesso: $17 / 06 / 2019$, às $20 \mathrm{~h} 33$.

${ }^{66} \mathrm{https://www.miga.org/} \mathrm{Acesso:} \mathrm{17/06/2019,} \mathrm{às} \mathrm{20h38.}$

${ }^{67} \mathrm{https://www.ndb.int/wp-content/uploads/2017/01/MOU-NDB-WBG.pdf} \mathrm{Acesso:} \mathrm{13/06/2019,} \mathrm{às} 22 \mathrm{~h} 01$.

${ }^{68} \mathrm{https://www.fonplata.org/} \mathrm{Acesso:} \mathrm{15/06/2019,} \mathrm{às} \mathrm{15h21.}$

${ }_{69}$ https://www.ndb.int/wp-content/uploads/2017/05/MOU-with-FONPLATAApril-2017.pdf Acesso: $13 / 06 / 2019$, às $21 \mathrm{~h} 45$.

${ }^{70} \mathrm{https}: / / \mathrm{www} . c a f . c o m / \mathrm{pt} / \mathrm{Acesso:}$ 15/06/2019, às $15 \mathrm{~h} 41$.

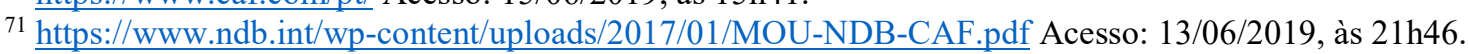


interesse mútuo; a troca de recursos humanos, como pesquisadores e experts, para suporte de projetos de interesse comum ${ }^{72}$.

O Inter-American Development Bank ${ }^{73}$ é um banco multilateral de desenvolvimento cujo o propósito é contribuir com o desenvolvimento social e econômico dos países da América Latina. O Inter-American Investment Corporation $^{74}$ é $^{-}$ uma organização multilateral que busca contribuir com o desenvolvimento latinoamericano através do apoio ao setor privado. $\mathrm{O}$ memorando de entendimento entre o NBD, o Inter-American Development Bank e o Inter-American Investment Corporation ${ }^{75}$ objetiva ações como: a participação conjunta em programas e projetos de desenvolvimento e infraestrutura; a exploração de oportunidades nas áreas de informações econômicas e serviços financeiros; a análise e a pesquisa de dados macroeconômicos; a troca de informações e o compartilhamento de conhecimento na área de gerenciamento de risco; a troca de boas práticas na área de desenvolvimento sustentável.

O Eurasian Development Bank $k^{76}$ é uma instituição financeira multilateral que visa apoiar a integração da Eurásia através do investimento, bem como proporcionar crescimento econômico dos seis membros da organização, quais sejam, Rússia, Armênia, Belarus, Cazaquistão, Quirguistão e Tajiquistão. A sede da instituição fica em Almaty no Cazaquistão. O memorando de entendimento entre o NBD e o Eurasian Development Bank $^{77}$ objetivas ações como: a identificação, preparação e co-financiamento de projetos de infraestrutura em países de interesse mútuo; a consulta periódica para a coordenação de operações e atividades; a exploração de oportunidades de cooperação no gerenciamento do tesouro; a pesquisa de dados macroeconômicos; a troca de informações sobre políticas internas e procedimentos de cada parte.

O European Bank for Reconstruction and Development ${ }^{78}$ é uma instituição financeira multilateral que visa a promoção da iniciativa privada e empresarial, tendo sido fundado em 1991. A organização possui 68 países membros. O memorando de

\footnotetext{
${ }^{72}$ Vale notar que os objetivos do NBD com a Corporación Andina de Fomento são os mesmos que o NBD possui com o FONPLATA.

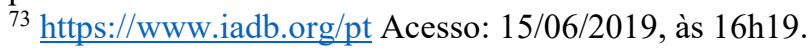

${ }^{74} \mathrm{https} / / / \mathrm{www}$. iic.org/en Acesso: 15/06/2019, às 16h21.

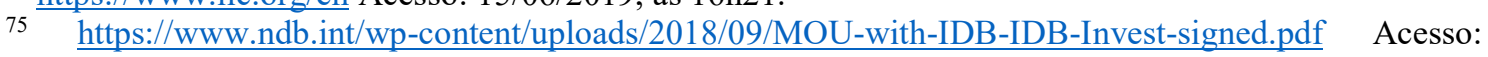
$13 / 06 / 2019$, às $21 \mathrm{~h} 48$.

${ }^{76}$ https://eabr.org/en/ Acesso: 16/06/2019, às 17h47.

$77 \mathrm{https://www.ndb.int/wp-content/uploads/2017/04/MOU-with-EDBApril-2017.pdf} \mathrm{Acesso:} \mathrm{13/06/2019,}$ às $21 \mathrm{~h} 50$.

${ }^{78}$ https://www.ebrd.com/home Acesso: 16/06/2019, às 18h51.
} 
entendimento entre o NBD e European Bank for Reconstruction and Development ${ }^{79}$ objetiva ações como: a troca de informações nas áreas de infraestrutura e desenvolvimento sustentável; a identificação de projetos com potencial de cofinanciamento; a iniciativa para a troca temporária de staff; a troca de know-how nas áreas de desenvolvimento de projetos.

O Asian Infrastructure Investment Bank ${ }^{80}$ é uma banco multilateral de desenvolvimento que visa melhorar indicadores sociais e econômicos da Ásia. A sede da organização fica em Pequim e são 97 membros espalhados ao redor do mundo, sendo a maioria localizada na Ásia e na Europa. As operações do referido banco se iniciaram em 2016. O memorando de entendimento entre o NBD e o Asian Infrastructure Investment Bank $^{81}$ objetiva ações como: a promoção de co-financiamento de projetos de desenvolvimento em países de interesse mútuo; a criação de setores e nível de colaboração temáticos nas áreas de projetos de infraestrutura; o treinamento mútuo de staff por meios de programas; a realização de fórum, seminários e workshops que promovam o compartilhamento de conhecimento e capacidades institucionais; a troca de informações sobre as respectivas regras, políticas e estratégias; a troca de experiências nas áreas de assistência técnica para preparação e implementação dos projetos de desenvolvimento.

O European Investment Bank ${ }^{82}$ é uma instituição financeira da União Europeia, com foco na realização de empréstimos. O memorando de entendimento entre o NBD e European Investment Bank ${ }^{83}$ objetiva ações como: a exploração da cooperação de infraestrutura e desenvolvimento sustentável de acordo com as respectivas políticas; a busca por co-financiamento de projetos de mútuo interesse em países escolhidos pelas partes; a troca de know-how técnico nas áreas de projetos de desenvolvimento, gerenciamento do tesouro, políticas públicas e pesquisa.

O International Investment Bank ${ }^{84}$ é uma instituição financeira multilateral que visa apoiar o desenvolvimento por meio do financiamento de pequenos e médios negócios, bem como de projetos de infraestrutura. A sede da organização é em Moscou e

\footnotetext{
79 https://www.ndb.int/wp-content/uploads/2017/04/MOU-with-EBRDApril-2017.pdf Acesso: $13 / 06 / 2019$, às $21 \mathrm{~h} 51$.

${ }^{80}$ https://www.aiib.org/en/index.html Acesso: 16/06/2019, às $19 \mathrm{~h} 36$.

81 https:/www.ndb.int/wp-content/uploads/2017/04/MOU-with-AIIBApril-2017.pdf Acesso: 20/03/2019 às $00 \mathrm{~h} 24$.

82 https://www.eib.org/en/index.htm Acesso: 17/06/2019, às 10h49.

83 https://www.ndb.int/wp-content/uploads/2017/04/MOU-with-EIBApril-2017.pdf Acesso: 13/06/2019, às $22 \mathrm{~h} 25$.

${ }^{84}$ https://iib.int/en Acesso: 17/06/2019, às $11 \mathrm{~h} 07$.
} 
são nove países membros: Rússia, Bulgária, Cuba, Eslováquia, Hungria, Mongólia, República Tcheca, Romênia e Vietnã. O memorando de entendimento entre o NBD e o International Investment Bank ${ }^{85}$ objetiva ações como: a promoção de co-financiamento de projetos de desenvolvimento em países de interesse mútuo; a realização de fórum, seminários e workshops que promovam o compartilhamento de conhecimento e capacidades institucionais; a criação de setores e nível de colaboração temáticos nas áreas de projetos de infraestrutura; a exploração de oportunidades de cooperação no gerenciamento do tesouro.

O Asian Development Bank ${ }^{86}$ é uma instituição financeira concebida na década de 1960 com a proposta de fomentar o crescimento econômico, principalmente na Ásia. A organização possui 68 países membros, sendo 49 asiáticos. O memorando de entendimento entre o NBD e o Asian Development Bank ${ }^{87}$ objetivas ações como: a exploração de possibilidades de co-financiamento, com fomento a integração e a conectividade; a colaboração em projetos de desenvolvimento; a contribuição para estudos e análises em tópicos de comum interesse.

De maneira geral, os memorandos de entendimento firmados entre o NBD e diversas instituições financeiras multilaterais envolvem aprendizado institucional mútuo bem como a possibilidade de co-financiamento em países nos quais haja interesse das partes signatárias de cada acordo. Como vários dos bancos multilaterais de desenvolvimento partícipes dos referidos acordos possuem dezenas de países membros, ficam ampliadas as possibilidades futuras de atuação do Banco do BRICS.

Conforme Andronova e Shelepov (2018), o NBD coloca ênfase na cooperação com bancos de multilaterais de desenvolvimento nos quais os países do BRICS exercem um papel de destaque. Os novos parceiros incluem grande instituições multilaterais que executam atividades essenciais fora do BRICS. As assinaturas dos memorandos de entendimento com tais instituições multilaterais indicam a intenção do BRICS de expandir o seu âmbito de operação.

Além da assinatura dos memorandos de entendimento, o NBD pode trazer mais atores para as políticas do BRICS diretamente através de seus projetos. Qobo e Soko (2015) destacam sobre a possibilidade de projetos financiados pelo NBD envolverem

\footnotetext{
${ }^{85}$ https://www.ndb.int/wp-content/uploads/2017/04/MOU-with-IIBArpil-2017.pdf Acesso: 13/06/2019, às $21 \mathrm{~h} 56$.

86 https://www.adb.org/ Acesso: 17/06/2019, às 21 h09.

87 https://www.ndb.int/wp-content/uploads/2017/01/MOU-ADB-NDB.pdf Acesso: 13/06/2019, às $22 \mathrm{~h} 09$.
} 
mais de um país, com impactos diretos que ultrapassam fronteiras. Um exemplo é o projeto denominado Lesotho Highlands Water Project Phase II $^{88}$. Trata-se de um projeto proposto pela África do Sul para transferir água do Lesoto para o rio Vaal, em território sul-africano. O Lesoto, apesar de não ser membro do BRICS, entrou em seu domínio de poder via um projeto de infraestrutura.

O NBD deu início à operacionalização do potencial da plataforma BRICS+Circle, aumentando o número de atores envolvidos nas relações de poder do BRICS (dimensão domínio do poder), por meio do estabelecimento de acordos diversos. Da mesma forma que uma norma não é necessariamente cumprida, uma norma também não é necessariamente descumprida. Não se trata de reificar o direito positivado, mas sim, de reconhecer que há um custo político para descumprimento de normas internacionais, por menor que seja, a depender do caso. Assim, por meio da realização de acordos, é possível expandir o alcance dos próprios interesses, como o BRICS tem feito por meio do NBD.

\subsection{Dimensão Custos do Poder}

Considerando as preferências dos atores fundadores de uma instituição, é complexa uma análise que busque verificar quais foram os interesses prevalecentes na criação de uma organização. No entanto, como a criação e a manutenção de uma instituição (como o Novo Banco de Desenvolvimento) acarreta custos para os atores criadores, é viável verificar que em que medida foi custoso o estabelecimento do Banco para os seus fundadores. Conforme a definição de Baldwin (2013), o exercício do poder possui custos, e o ator prevalecente numa relação de poder é aquele que alcança os seus interesses com os menores custos (sejam absolutos ou relativos).

Os custos envolvem não apenas capital financeiro, mas também capital político. Para limitações da abrangência da análise, o presente foco é no aspecto financeiro. Cada membro do Banco se compromissou com o investimento de recursos para a formação de seu capital social subscrito inicial de 50 bilhões de dólares (igualmente distribuído entre os membros fundadores ${ }^{89}$ ), bem como para a formação de seu capital autorizado inicial de 100 bilhões de dólares. O capital social subscrito é "o compromisso assumido de entrega de valores” (Bächtold, 2011, p. 200) por parte dos integrantes da instituição,

\footnotetext{
${ }^{88}$ Novo Banco de Desenvolvimento: https://www.ndb.int Acesso: 20/03/2019, às 00h14.

${ }^{89}$ BRICS. Declaração de Fortaleza (VI Cúpula). 2014 (12 ${ }^{\circ}$ Parágrafo) c/c BRICS. Acordo Constitutivo sobre o Novo Banco de Desenvolvimento. 2014 (Art. 7, alínea "c").
} 
formando o seu patrimônio líquido. O capital autorizado é "o limite do valor das operações do banco" (Calixtre e Barros, 2010, p. 23), abarcando os recursos para os financiamentos efetuados pela organização.

A manutenção do NBD não possui custos em todos os seus componentes. Os governadores e seus suplentes não recebem salário pela função que exercem. Já o Presidente do Banco recebe salário, o qual é determinado pelo Conselho de Governadores $^{90}$. Ademais, o staff do NBD não é grande em comparação com outros bancos multilaterais de desenvolvimento. Nos primeiros três anos de operação (Suchodolski e Demeulemeester, 2018), o NBD atuou com cerca de 100 funcionários, enquanto o Asian Development Bank possui mais de 3.500 empregados, e o International Bank for Reconstruction and Development (IBRD) mais de 10 mil.

Os custos de criação e de manutenção do NBD para cada membro pode ser auferido levando em consideração os pesos relativos de tais custos em relação ao Produto Interno Bruto de cada país. Segundo o Relatório Anual do NBD de $2017^{91}$, de 3 de julho de 2015 até 31 de dezembro de 2016, a Rússia contribuiu com 600 milhões de dólares para capital social subscrito do Banco. No mesmo período, Brasil, Índia, China e África do Sul contribuíram com 400 milhões de dólares cada um. Conforme o mesmo Relatório, até 31 de dezembro de 2017, a Rússia contribuiu com 1 bilhão de dólares para capital social subscrito do Banco. Subtraindo o valor contribuído até 31/12/2016, temos que só em 2017 a Rússia contribuiu com 400 milhões de dólares ao NBD. Até 31 de dezembro de 2017, Brasil, Índia, China e África do Sul contribuíram com 700 milhões de dólares cada um. Subtraindo o valor contribuído até 31/12/2016, temos que só em 2017, Brasil, Índia, China e África do Sul contribuíram com 300 milhões de dólares ao NBD. Lembrando que o valor que cada membro deve contribuir obrigatoriamente para o Banco é de 10 bilhões de dólares, pois o valor do capital social subscrito de 50 bilhões é dividido igualmente entre os membros fundadores ${ }^{92}$.

O PIB do Brasil era de 1,8 trilhão de dólares em 2015, de 1,8 trilhão de dólares em 2016, e de 2,05 trilhões de dólares em $2017^{93}$. Os 400 milhões que o Brasil contribuiu

\footnotetext{
${ }^{90}$ BRICS. Acordo Constitutivo sobre o Novo Banco de Desenvolvimento. 2014 (Art. 11, alínea "g" c/c alínea "h"). O tópico sobre a dimensão do poder Agência vs. Estrutura, da presente pesquisa, apresenta informações sobre os governadores.

91 Disponível em: https://www.ndb.int/wp-content/uploads/2018/07/NDB_AR2017.pdf Acesso: $05 / 06 / 2019$, às $18 \mathrm{~h} 30$.

${ }^{92}$ BRICS. Declaração de Fortaleza (VI Cúpula). 2014 (12 ${ }^{\circ}$ Parágrafo) c/c BRICS. Acordo Constitutivo sobre o Novo Banco de Desenvolvimento. 2014 (Art. 7, alínea "c").

93 Fonte: https://www.imf.org/external/datamapper/NGDPD@WEO/OEMDC/ADVEC/WEOWORLD/ Acesso: 06/06/2019, às $19 \mathrm{~h} 38$.
} 
para o Banco, somando os anos de 2015 e $2016^{94}$, representam aproximadamente 0,0111\% da soma de seus PIBs nos dois anos. Os 300 milhões que o Brasil contribuiu para o Banco, no ano de 2017, representam aproximadamente $0,0146 \%$ de seu PIB do mesmo ano.

O PIB da Rússia era 1,36 trilhão de dólares em 2015, de 1,28 trilhão de dólares em 2016, e de 1,58 trilhão de dólares em $2017^{95}$. Os 600 milhões que a Rússia contribuiu para o Banco, somando os anos de 2015 e 2016, representam aproximadamente 0,0227\% da soma de seu PIBs nos dois anos. Os 400 milhões que a Rússia contribuiu para o Banco, no ano de 2017, representam aproximadamente 0,0253\% de seu PIB do mesmo ano.

O PIB da Índia era de 2,1 trilhões de dólares em 2015, de 2,29 trilhões de dólares em 2016, e de 2,65 trilhões de dólares em $2017^{96}$. Os 400 milhões que a Índia contribuiu para o Banco, somando os anos de 2015 e 2016, representam aproximadamente 0,0091\% da soma de seus PIBs nos dois anos. Os 300 milhões que a Índia contribuiu para o Banco, no ano de 2017, representam aproximadamente 0,0113\% de seu PIB do mesmo ano.

O PIB da China era de 11,23 trilhões de dólares em 2015, de 11,22 trilhões de dólares em 2016, e de 12,06 trilhões de dólares em 201797. Os 400 milhões que a China contribuiu para o Banco, somando os anos de 2015 e 2016, representam aproximadamente 0,0017\% da soma de seus PIBs nos dois anos. Os 300 milhões que a China contribuiu para o Banco, no ano de 2017, representam aproximadamente $0,0025 \%$ de seu PIB do mesmo ano.

O PIB da África do Sul era de 317,58 bilhões de dólares em 2015, de 296,27 bilhões de dólares em 2016, e de 349,43 bilhões de dólares em $2017^{98}$. Os 400 milhões que a África do Sul contribuiu para o Banco, somando os anos de 2015 e 2016, representam aproximadamente $0,0651 \%$ da soma de seus PIBs nos dois anos. Os 300 milhões que a África do Sul contribuiu para o Banco, no ano de 2017, representam aproximadamente $0,0858 \%$ de seu PIB do mesmo ano.

Tanto para o biênio 2015-2016 como para o ano de 2017, a China é o país com menor custo relativo de criação e manutenção do NBD $(0,0017 \%$ e $0,0025 \%$, respectivamente). No outro extremo, a África do Sul é o membro do Banco com maior

\footnotetext{
${ }^{94}$ Como o Banco inicial suas atividades em 03/07/2015 e como não há discriminação das contribuições dos países para o ano de 2015, no de Relatório Anual do NBD de 2017, as contribuições dos anos de 2015 e 2016 são analisadas conjuntamente.

95 Idem.

96 Idem.

97 Idem.

${ }^{98}$ Idem.
} 
custo relativo $(0,0651 \%$ e $0,0858 \%$, respectivamente). O custo do país africano é cerca de 50 vezes maior do que o custo da China. Índia, Brasil e Rússia ocupam posições intermediárias, com custos aproximadamente cinco, seis e dez vezes maiores que o da China, respectivamente. Vale lembrar que a Rússia é o membro que mais contribuiu para o Banco nos três anos considerados, sendo o país com menor quantia a ser paga para o atingimento de sua parcela do capital social do NBD.

A sensibilidade (Keohane e Nye, 2012) indica os custos imediatos internos de um país, resultantes de mudanças acontecidas no exterior, antes que políticas alternativas sejam implementadas por um dado país. Num cenário em que o Banco entre em crise e quebre, a China seria o país menos afetado e a África do Sul o país mais afetado, com base nos dados acima da relação capital investido/PIB de cada país membro do Banco. Índia, Brasil e Rússia ocupariam posições intermediárias quanto aos impactos sofridos no referido cenário.

A vulnerabilidade (Keohane e Nye, 2012) é o custo das medidas realizadas por um país para lidar com as mudanças acontecidas no exterior, isto é, é o custo imposto que o agente sofre, após as suas políticas terem sido modificadas para lidar com as mudanças externas. Como não se sabe quais políticas seriam adotadas por cada membro do BRICS num cenário em que o Banco entre em crise e quebre, não há como fazer análises acerca da vulnerabilidade de cada membro do NBD.

Mesmo partindo do pressuposto que a criação e a manutenção do NBD são interesses de todos os membros do BRICS, numa mesma intensidade, a China é o ator que mais exerceu poder, no que se refere a relação custo-benefício. Apesar dos custos absolutos serem aproximadamente os mesmo entre os anos de 2015 a 2017, com todos os membros contribuindo uma mesma quantia para o Banco (700 milhões de dólares), com exceção da Rússia que contribuiu mais (1 bilhão de dólares), os custos relativos são muito menores para a China, devido ao seu PIB ser maior do que a soma dos PIBs de todos os demais membros do BRICS juntos.

\subsection{Dimensão Peso do Poder}

O peso (Baldwin, 2013) indica à probabilidade do poder de um agente afetar o comportamento de outro. Um ator com $90 \%$ de chances de realizar o seu interesse numa dada negociação é mais poderoso do que outro ator com $30 \%$ de chances, tudo mais 
mantido constante (ceteris paribus). No entanto, existe o problema de se mensurar a probabilidade de um agente influenciar as ações de outro.

Para abordar a dimensão peso do poder no âmbito do NBD, vamos analisar brevemente a probabilidade de a China ter influenciado os demais membros do BRICS a aceitarem uma cidade chinesa como sede do Banco, por ser o país com mais recursos econômicos. Conforme definido no Art. 3 do Acordo Constitutivo, Xangai é a sede do Banco. Para tal abordagem vamos utilizar o método Qualitative Comparative Analysis QCA (Rihoux, 2017; de Meur et al, 2006) comparando os locais de sede de 23 diferentes bancos multilaterais de desenvolvimento (BMD) identificados por Suchodolski (2018).

Num Cenário "A", em que as sedes da maioria dos BMD encontram-se nos respectivos países com maior PIB, depreende-se que é uma prática comum a escolha dos países com mais recursos econômicos para sediar as referidas instituições. Logo, não necessariamente, tais países (de maior PIB) exerceram poder com um peso maior do que os demais membros, na decisão acerca da localização da sede. Neste Cenário, pode-se interpretar a existência de uma aceitação pelo costume, sem necessidade de maiores convencimentos para a citada decisão.

Num Cenário "B", em que as sedes da maioria dos BMD não se encontram nos respectivos países com maior $\mathrm{PIB}$, depreende-se que não é uma prática comum a escolha dos países com mais recursos econômicos para sediar as referidas instituições. Logo, há um aumento da probabilidade de que tais países (de maior PIB), quando possuem a sede, tenham exercido poder com um peso maior do que os demais membros, na decisão acerca da localização da sede. Neste Cenário, pode-se interpretar a não existência de uma aceitação pelo costume, havendo alguma necessidade de maiores convencimentos para a citada decisão.

O Método QCA possui duas variantes principais (Rihoux, 2017; de Meur et al, 2006): Most Similar cases with Different Outcomes (MSDO) e Most Different cases with Similar Outcomes (MDSO). Em nossa análise se aplica o MDSO, pois cada banco multilateral de desenvolvimento possui um contexto próprio, sendo cada um diferente dos demais devido as suas especificidades. O MDSO é aplicável pois o objetivo do presente tópico é verificar justamente em que medida bancos multilaterais de desenvolvimento diferentes apresentam um resultado semelhante. Para o Cenário “A”, a sede no país de maior PIB. Para o Cenário "B”, a sede num país que não tenha o maior PIB. Vejamos na tabela abaixo, qual Cenário se verifica: 
Tabela 1: Sedes dos Bancos Multilaterais de Desenvolvimento (BMD)

\begin{tabular}{|c|c|c|}
\hline BMD & País com a Sede & País de maior PIB \\
\hline $\begin{array}{l}\text { Novo Banco de } \\
\text { Desenvolvimento (NBD) }\end{array}$ & China (Xangai) & China \\
\hline $\begin{array}{l}\text { African Development } \\
\text { Bank (AfDB) }\end{array}$ & Costa do Marfim (Abidjan) & África do Sul \\
\hline $\begin{array}{l}\text { Arab Bank for Economic } \\
\text { Development in Africa } \\
\text { (BADEA) }\end{array}$ & Sudão (Khartoum) & Arábia Saudita \\
\hline $\begin{array}{l}\text { Asian Development Bank } \\
\text { (ADB) }\end{array}$ & Filipinas (Mandaluyong) & Estados Unidos \\
\hline $\begin{array}{l}\text { Asian Infrastructure } \\
\text { Investment Bank (AIIB) }\end{array}$ & China (Pequim) & China \\
\hline 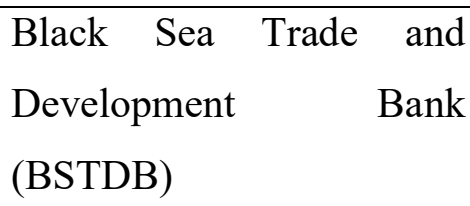 & Grécia (Tessalônica) & Rússia \\
\hline $\begin{array}{l}\text { Caribbean Development } \\
\text { Bank (CDB) }\end{array}$ & Barbados (Saint Michael) & Jamaica \\
\hline $\begin{array}{lr}\text { Central African } & \text { States } \\
\text { Development } & \text { Bank } \\
\text { (BDEAC) } & \end{array}$ & Congo (Brazzaville) & $\begin{array}{l}\text { República Democrática do } \\
\text { Congo }\end{array}$ \\
\hline $\begin{array}{l}\text { Central American Bank for } \\
\text { Economic Integration } \\
(\mathrm{CABEI})\end{array}$ & Honduras (Tegucigalpa) & Espanha \\
\hline $\begin{array}{l}\text { Council of Europe } \\
\text { Development Bank (CEB) }\end{array}$ & França (Paris) & Alemanha \\
\hline $\begin{array}{l}\text { Development Bank of } \\
\text { Latin America (CAF) }\end{array}$ & Venezuela (Caracas) & Brasil \\
\hline $\begin{array}{l}\text { East-African Development } \\
\text { Bank (EADB) }\end{array}$ & Uganda (Kampala) & Quênia \\
\hline $\begin{array}{ll}\text { Economic } & \text { Cooperation } \\
\text { Organization } & \text { Trade and }\end{array}$ & Turquia (Istambul) & Turquia \\
\hline
\end{tabular}




\begin{tabular}{|c|c|c|}
\hline $\begin{array}{l}\text { Development } \quad \text { Bank } \\
\text { (ETDB) }\end{array}$ & & \\
\hline $\begin{array}{l}\text { Eurasian Development } \\
\text { Bank (EDB) }\end{array}$ & Cazaquistão (Almaty) & Rússia \\
\hline $\begin{array}{ll}\text { European Bank for } \\
\text { Reconstruction } & \text { and } \\
\text { Development (EBRD) } & \end{array}$ & Reino Unido (Londres) & Estados Unidos \\
\hline $\begin{array}{l}\text { European Investment Bank } \\
\text { (EIB) }\end{array}$ & Luxemburgo (Kirchberg) & Alemanha \\
\hline $\begin{array}{l}\text { Fondo Financiero para el } \\
\text { Desarrollo de la Cuenca del } \\
\text { Plata (FONPLATA) }\end{array}$ & Bolívia (Sucre) & Brasil \\
\hline $\begin{array}{l}\text { Inter-American } \\
\text { Development } \quad \text { Bank } \\
\text { (IADB) }\end{array}$ & $\begin{array}{l}\text { Estados Unidos } \\
\text { (Washington) }\end{array}$ & Brasil \\
\hline $\begin{array}{ll}\text { International Bank for } \\
\text { Reconstruction } & \text { and } \\
\text { Development (IBRD) } & \end{array}$ & $\begin{array}{l}\text { Estados Unidos } \\
\text { (Washington) }\end{array}$ & Estados Unidos \\
\hline $\begin{array}{l}\text { International Investment } \\
\text { Bank (IIB) }\end{array}$ & Hungria (Budapeste) & Rússia \\
\hline $\begin{array}{l}\text { Islamic Development Bank } \\
\text { (IsDB) }\end{array}$ & Arábia Saudita (Jidá) & Indonésia \\
\hline $\begin{array}{l}\text { Nordic Investment Bank } \\
\text { (NIB) }\end{array}$ & Finlândia (Helsinque) & Suécia \\
\hline $\begin{array}{l}\text { West African Development } \\
\text { Bank (BOAD) }\end{array}$ & Togo (Lomé) & Costa do Marfim \\
\hline
\end{tabular}

Elaboração própria com dados extraídos de Suchodolski (2018), do sítio do FMI e dos sítios oficiais dos citados BMDs. Obs.: Alguns BMDs possuem membros extra-regionais.

Conforme os dados acima, o Cenário que se verifica é o "B". Ao contrário do que possa se supor no senso comum, não é praxe internacional a sede de um banco multilateral de desenvolvimento ficar no país de maior PIB. Dos 23 bancos, apenas quatro estão sediados no país de maior PIB, sendo que em dois deles o país é a China (NBD e AIIB $^{99}$ ).

\footnotetext{
${ }^{99}$ O empenho da China no NBD e no AIIB mostra que o país é um player em diferentes "tabuleiros".
} 
Os outros dois casos de exceção ocorrem com o Estados Unidos (no IBRD) e a Turquia (no Economic Cooperation Organization Trade and Development Bank).

A situação mais frequente é a que ocorre nos outros 19 bancos. Por exemplo, o Brasil é o membro com mais recursos econômicos em três BMD (Development Bank of Latin America, FONPLATA e Inter-American Development Bank ${ }^{100}$ ), mas em nenhum deles possui a sede. A Rússia também é o membro com mais recursos econômicos em três BMD (Eurasian Development Bank, Eurasian Development Bank e International Investment Bank), mas em nenhum deles possui a sede. A África do Sul é o membro de maior PIB do African Development Bank, mas a sede fica na Costa do Marfim. A Arábia Saudita possui a sede do Islamic Development Bank, um BMD cujo membro com mais recursos econômicos é a Indonésia. Já no Arab Bankfor Economic Development in Africa, a Arábia Saudita é o país com maior PIB, mas a sede fica no Sudão.

Deste modo, é de se supor que, a princípio, não era interesse prioritário de Brasil, Rússia, Índia e África do Sul que a sede fosse na China, pois não é costume internacional a sede de um BMD ficar no país de maior PIB (talvez para se demonstrar uma distribuição do poder no âmbito da instituição). Com isso, é provável que a China tenho exercido um peso maior na decisão que definiu a cidade de Xangai como sede do NBD, do que os demais membros da instituição.

Segundo Qobo e Soko (2015), ficaram bem distribuídas as posições de destaque na estrutura institucional do NBD, que envolve o Presidente do Banco, o Presidente Conselho de Governadores, o Presidente Conselho de Diretores e a sede. A Índia ocupou a primeira cadeira de Presidente do Banco. A Rússia ocupou a primeira cadeira de Presidente do Conselho de Governadores. O Brasil ocupou a primeira cadeira de Presidente Conselho de Diretores. A sede do Banco ficou na China e a África do Sul ficou com o primeiro escritório regional.

Discordamos da visão dos citados autores. Com tal distribuição, a vantagem ficou com a China. Pois as presidências do Banco, do Conselho de Governadores e do Conselho de Diretores são rotativas, mas não a sede. Além disso, não há grande vantagem para a África do Sul ter o primeiro escritório regional, uma vez que os outros membros (sem a sede) também terão os seus respectivos escritórios regionais.

\footnotetext{
100 Vale notar que a sede do Inter-American Development Bank fica num país não membro (o Estados Unidos).
} 


\section{APLICAÇÃO DAS DIMENSÕES DO PODER AO NBD - PARTE II}

Neste capítulo, aplicamos ao Novo Banco de Desenvolvimento as dimensões do poder que identificamos principalmente nas abordagens de Strange (1994), Nye (2011), Wight (2002), Barnett e Duvall (2005), (Berger, 2005) e Stuenkel (2017b), quais sejam: agência vs. estrutura, método de aplicação de meios, geográfica, incidência, grau de dominância e grau de transição. O presente marco teórico, além de ser um instrumental analítico da hipótese, é uma tentativa de contribuir com o desenvolvimento da literatura, dando continuidade ao trabalho iniciado por Baldwin (2013), que propôs cinco dimensões do poder. Para cada dimensão há um tópico próprio, com exemplos empíricos que fundamentam as análises.

\subsection{Dimensão Agência vs. Estrutura}

O Novo Banco de Desenvolvimento possui a sua própria estrutura institucional, que inclui a Presidência (com Presidente e Vice-Presidentes), o Conselho de Governadores e o Conselho de Diretores. A sede do Banco é em Xangai na China. A África do Sul recebeu o primeiro escritório regional, na cidade de Johanesburgo. Posteriormente, Brasil, Rússia e Índia também terão os seus escritórios regionais ${ }^{101}$.

A adesão de novos membros é aprovada pelo Conselho de Governadores por uma maioria especial. Qualquer membro das Nações Unidas pode aderir ao Banco. Os países que aderem não necessariamente precisam ser tomadores de empréstimos. Países não membros do Banco podem ser observadores em reuniões do Conselho de Governadores, caso sejam convidados por algum país membro do Banco. Instituições financeiras internacionais também podem ser observadoras nas referidas reuniões, por decisão do próprio Conselho de Governadores ${ }^{102}$.

Os governadores são de nível ministerial, sendo um indicado por cada país membro (havendo também um suplente para cada governador). A reunião do Conselho de Governadores ocorre no mínimo uma vez por ano, com a necessidade do quórum da maioria de seus membros, desde que representem $2 / 3$ do total dos votos. A ocorrência de

\footnotetext{
${ }^{101}$ BRICS. Acordo Constitutivo sobre o Novo Banco de Desenvolvimento. 2014.

102 Idem.
} 
outras reuniões, além do encontro anual, pode ser determinada pelos próprios governadores, ou por convocação do Conselho de Diretores ${ }^{103}$.

Entre outras, são competências exclusivas do Conselho de Governadores: eleger o Presidente do Banco, emendar o Acordo Constitutivo, suspender um membro, admitir novos membros, determinar a distribuição dos lucros líquidos do Banco, autorizar acordos com outras organizações internacionais, aprovar o planejamento estratégico do Banco (com vigência de 5 anos) $)^{104}$.

Os diretores exercem mandado de dois anos, sendo um indicado por cada país membro (havendo também um suplente para cada diretor). A reunião do Conselho de Diretores ocorre uma vez a cada três meses, com a necessidade do quórum da maioria de seus membros, desde que representem $2 / 3$ do total dos votos. A ocorrência de outras reuniões pode ser determinada pelo Conselho de Governadores ${ }^{105}$.

O Conselho de Diretores é responsável, principalmente, pela aprovação do orçamento do Banco, pela apresentação das contas de cada exercício financeiro (para apreciação do Conselho de Governadores) e pela tomada de decisões acerca de empréstimos, investimentos e garantias. O referido Conselho também pode indicar a criação de comitês, sendo obrigatória a formação do Comitê de Crédito e Investimento ${ }^{106}$.

O Presidente do Banco é eleito pelo Conselho de Governadores, de forma rotativa entre os membros fundadores. O Presidente é membro do Conselho de Diretores, sem direito a voto, exceto na situação de empate. O Presidente pode participar das reuniões do Conselho de Governadores, sem direito a voto. Cada membro fundador que não ocupa o cargo de Presidente tem um Vice-Presidente. Os Vice-Presidentes são escolhidos pelo Conselho de Governadores, com base na recomendação do Presidente, o qual também pode recomendar a demissão de Vices. O Presidente e os Vice-Presidentes exercem mandado de cincos anos, sem renovação. Há uma exceção para o primeiro mandado que é de seis anos ${ }^{107}$.

O Presidente e os Vice-Presidentes fazem parte do Comitê de Crédito e Investimento, o qual toma decisões sobre empréstimos, investimentos e garantias. $\mathrm{O}$ Presidente também é chefe dos funcionários que exercem atividades operacionais, sendo

\footnotetext{
${ }^{103}$ Idem.

104 Idem.

${ }^{105}$ Idem

106 Idem.

107 Idem.
} 
responsável por organizar, indicar e demitir funcionários e dirigentes, com orientação dos diretores $^{108}$.

As decisões são tomadas por maioria simples, exceto em alguns casos, nos quais é determinada a maioria qualificada de $2 / 3$ do total dos votos ou maioria especial, que compreende os votos de quatro membros fundadores. As decisões do Conselho de Governadores sobre a realização de reuniões do Conselho de Diretores (além dos encontros trimestrais) depende de maioria qualificada. As decisões do Conselho de Governadores para estabelecer e administrar fundos especiais do Banco também dependem de maioria qualificada. Caso ocorra a adesão de novos membros ao Banco, a intensidade dos votos dos membros fundadores não será menor do que $55 \%$ do total ${ }^{109}$.

A maioria especial é utilizada pelo Conselho de Governadores para emendar o Acordo Constitutivo do Banco, para decidir sobre a adesão de novos membros, para suspender e cessar a suspensão de um membro, para destituir o Presidente do Banco de seu cargo, para aumentar o capital social do Banco, para decidir sobre o número de ações que cada membro deve subscrever no capital social do Banco, para determinar o término de suas operações (isto é, o encerramento de todas as suas atividades), para decidir sobre o método de escolha de diretores e seus suplentes, para realizar a distribuição de ativos e para aprovar a política de atuação do Banco relativa a projetos em países não membros. O Conselho de Diretores também aprova por maioria especial projetos em países não membros ${ }^{110}$.

A estrutura institucional do Novo Banco de Desenvolvimento, como toda estrutura, constrange, limita e orienta as ações dos agentes. Diferentes tipos de maiorias são necessários conforme o objeto da decisão, de modo que a agregação de preferências dos atores precisa ser quase consensual, por exemplo, no caso da aprovação da admissão de um novo membro.

Como em nenhuma situação há necessidade de consenso, em caso de ausência de unanimidade, há vencedores e vencidos. Por um lado, tal aspecto estrutural faz com que alguns atores possam ter seus interesses contrariados em detrimento das preferências de outros membros. Por outro, caso o consenso fosse necessário, não haveria a distinção entre ganhadores e perdedores nas decisões, no entanto, em situações nas quais o consenso não fosse atingido, a ação da instituição ficaria paralisada, prejudicando de certa

\footnotetext{
108 Idem.

109 Idem.

${ }^{110}$ Idem.
} 
forma todos os atores membros, uma vez que não se adere uma instituição para vê-la inativa, sem a realização de seus propósitos fundacionais.

A estrutura institucional do NBD foi construída conjuntamente e nenhum dos seus membros possui isoladamente poder estrutural. No entanto, os membros fundadores do Banco possuem, conjuntamente, um poder estrutural que lhes garantem 55\% do total de votos, em caso de ampliação no número de membros. Além disso, verifica-se poder estrutural dos membros pioneiros com a definição de maioria especial, a qual é composta pelo voto afirmativo de quatro membros fundadores. E tais regras dificilmente serão alteradas no futuro, pois para emendar o Acordo Constitutivo é necessária justamente uma maioria especial.

O igual número de integrantes por país no Conselho de Governadores e no Conselho de Diretores confere equitativo poder aos agentes membros do Banco, possuindo apenas vantagem momentânea, no Conselho de Diretores, o país membro que ocupa a Presidência do Banco, pois nas situações de empate, o Presidente exerce o voto de desempate no referido Conselho. Como a Presidência é rotativa, tal vantagem também varia entre os membros fundadores, sendo mais um poder estrutural dos mesmos, pois somente os países fundadores podem ocupar a Presidência do Banco.

Como ressaltado por Nye (2011), é difícil verificar o grau de presença ou de ausência de voluntarismo nas ações dos atores, para identificar em que medida um poder estrutural contribuiu ou não para a formação das preferências dos atores. É improvável que a estrutura de um banco multilateral de desenvolvimento, nos seus primeiros anos de existência, consiga moldar preferências de seus membros. Por outro lado, como o NBD foca em projetos de infraestrutura, o Banco apresenta limitações de agenda aos atores. Por exemplo, um membro do Banco que tenha interesse em realizar ações para o desenvolvimento através da melhoria da saúde de sua população, com novas vacinas para imunização de doenças tropicais, não conseguirá financiamento para tal propósito, pois o Banco não financia pesquisas científicas. Para receber financiamento do NBD, os agentes precisam se adaptar à agenda institucional da organização.

Caso algum membro do BRICS possua isoladamente algum poder estrutural no âmbito do NBD, tal membro é a China, por ser o país sede da organização. Possuir a sede implica conter o centro das comunicações, das decisões, das instalações e do staff da instituição. Os demais aspectos da relevância da sede foram abordados no tópico sobre a dimensão peso do poder. 
A estrutura do Banco não engessa a atuação dos agentes, pois cada membro da organização é apto para a realização de ações, como a proposição de projetos de infraestrutura. Até 31/05/2019, foram propostos 37 projetos, dos quais 35 foram aprovados até a referida data. O Brasil propôs apenas cinco projetos, sendo um pelo Banco Nacional de Desenvolvimento Econômico e Social (BNDES), um pela Petróleo Brasileiro SA (Petrobrás), um pelo Governo do Estado do Pará (PA), um pelo Governo do Estado do Maranhão (MA) e um pelo Município de Sorocaba (SP), sendo que este último não foi aprovado até o fim de maio de $2019^{111}$.

O Brasil é uma federação formada pelos entes políticos União, Estados, Distrito Federal e Municípios ${ }^{112}$. Cada ente federativo possui sua própria administração direta, podendo também possuir uma administração indireta (com autarquias, fundações, empresas públicas e sociedades de economia mista) ${ }^{113}$. Dos 5570 Municípios brasileiros $^{114}$, apenas um apresentou projeto ao NBD (Sorocaba/SP). Entre os 26 Estados e o Distrito Federal, apenas dois Estados propuseram projetos ao Banco (MA e PA). A União, via administração direta, não apresentou nenhum projeto ao NBD. Apenas uma empresa pública $\left(\right.$ BNDES $\left.^{115}\right)$ e uma sociedade de economia mista (Petrobrás ${ }^{116}$ ), vinculadas à União, propuseram projetos ao Banco. Tais dados indicam que o Brasil utilizou pouco o seu poder de agência, isto é, o país foi pouco propositivo e explorou pouco as possibilidades permitidas pela estrutura institucional do NBD, no que se refere à apresentação de projetos de infraestrutura.

A Rússia apresentou seis projetos, sendo um pela Public Joint Stock Company (SIBUR Holding) $)^{117}$ e um pelo Eurasian Development Bank and International Investment Bank. Todos aprovados até a data supracitada. A Índia propôs nove projetos, sendo um

\footnotetext{
${ }^{111} \mathrm{https}$ ://www.ndb.int/projects/list-of-all-projects/ Acesso: 31/05/2019, às $21 \mathrm{~h} 01$.

112 Para mais informações sobre a organização político-administrativa do Brasil, ver: MORAES, Alexandre de. Direito Constitucional. São Paulo: Atlas, 2003 (13 Ed.).

${ }^{113}$ Para mais informações sobre administração direta e administração indireta (incluindo as definições de autarquias, fundações, empresas públicas e sociedades de economia mista), ver: DI PIETRO, Maria Sylvia Zanella. Direito Administrativo. São Paulo: Atlas, 2014 (27 $7^{\mathrm{a}}$ Ed.).

114 Número de municípios brasileiros conforme o https://biblioteca.ibge.gov.br/visualizacao/livros/liv95013.pdf Acesso: 02/06/2019, às 20h39.

${ }^{115}$ O BNDES é uma empresa pública, conforme o seu sítio oficial: https://www.bndes.gov.br/wps/portal/site/home/quem-somos Acesso: 02/06/2019, às 20h40.

116 A Petrobrás é um sociedade de economia mista, conforme 0 seu Estatuto: http://transparencia.petrobras.com.br/sites/default/files/Estatuto-Social-AGOE-27-Abril-2017Portugues.pdf Acesso: 02/06/2019, às 20h44.

117 Empresa petroquímica russa. Sítio oficial: https://www.sibur.ru/en/about/overview/ Acesso: $04 / 06 / 2019$, às $17 \mathrm{~h} 28$.
} 
pendente de aprovação até o fim de maio de 2019. Um dos projetos indianos foi proposto via Canara Bank, já tendo sido aprovado ${ }^{118}$.

A China propôs 11 projetos, todos já aprovados. A África do Sul apresentou seis projetos, dois pela Eskom Holdings SOC $L t d .{ }^{119}$, um pela Industrial Development Corporation of South Africa Limited (IDC) ${ }^{120}$, um pela Trans-Caledon Tunnel Authority ${ }^{121}$, um pelo The Development Bank of Southern Africa (DBSA) e um pelo Transnet SOC $L_{t d}{ }^{122}$. Todos estes projetos sul-africanos já foram aprovados ${ }^{123}$.

A quantidade de projetos de infraestrutura apresentados por país é um indicador útil para demonstrar o interesse e a atitude dos agentes, pois não há limitação estrutural para constranger a realização de tal ato, bastando competência profissional para a elaboração de projetos (a qual se espera que agentes gestores de Estado possuam) e interesse político em seguir tal caminho para o desenvolvimento. Brasil, Rússia e África do Sul apresentaram menos de $1 / 5$ dos projetos propostos até 31/05/2019. Índia e China propuseram juntas mais da metade dos projetos apresentados no NBD até a data citada, sendo assim, os países que mais demonstraram poder de agência, face às possibilidades existentes no âmbito da instituição.

Obter um empréstimo bancário para o financiamento de um projeto de infraestrutura acarretará um aumento do passivo do país (dívida), no entanto, cada membro do BRICS pode compensar a dívida com crescimento econômico. Além disso, cada país já se comprometeu com o investimento de recursos para a composição do capital social subscrito do Banco (inicialmente de 50 bilhões de dólares), bem como para a composição do seu capital autorizado (inicialmente de 100 bilhões de dólares). O capital social subscrito é "o compromisso assumido de entrega de valores" (Bächtold, 2011, p. 200) por parte dos membros da organização, compondo o seu patrimônio líquido. O capital autorizado é "o limite do valor das operações do banco" (Calixtre e Barros, 2010, p. 23), incluindo os recursos para os financiamentos realizados pela instituição. Um membro do NBD (que por definição deve contribuir com o capital social e com o capital

\footnotetext{
$118 \mathrm{https}$ ://www.ndb.int/projects/list-of-all-projects/ Acesso: 31/05/2019, às 21h01.

119 Empresa pública de eletricidade da África do Sul. Sítio oficial: http://www.eskom.co.za/Pages/Landing.aspx Acesso: 04/06/2019, às 17 h36.

${ }^{120}$ Instituição financeira da África do Sul para o desenvolvimento. Sítio oficial: https://www.idc.co.za/ Acesso: 04/06/2019, às 17h40.

${ }^{121}$ Agência do Departamento de Águas e Saneamento da África do Sul. Sítio oficial: https://www.tcta.co.za/ Acesso: 04/06/2019, às 17h43.

122 Companhia ferroviária, portuária e de dutos da África do Sul. Sítio oficial: https://www.transnet.net/AboutUs/Pages/Overview.aspx Acesso: 04/06/2019, às 17 h47.

${ }^{123}$ https://www.ndb.int/projects/list-of-all-projects/ Acesso: 31/05/2019, ás $21 \mathrm{~h} 01$.
} 
autorizado) e que apresenta poucos projetos próprios, acaba por financiar principalmente projetos de outros membros.

O valor dos empréstimos para os projetos de infraestrutura é outro indicador para a análise da atuação dos agentes membros do BRICS, na utilização da instituição NBD como instrumento para o desenvolvimento. Conforme a tabela abaixo, a China é o país que mais utiliza recursos do Banco, superando os 3 bilhões de dólares em empréstimos. Apesar de Rússia e África do Sul juntos terem apresentado mais projetos do que a China (12 a 11), os recursos para projetos chineses superam os recursos para projetos russos e sul-africanos somados (cerca de 3,2 bilhões de dólares contra cerca de 2,9 bilhões). $\mathrm{O}$ Brasil, apesar de só ter proposto um projeto a menos do que Rússia e África do Sul, os recursos para os seus projetos são menos da metade dos valores dos projetos russos e sulafricanos, que considerados separadamente alcançam cerca 1,4 bilhão de dólares cada, contra cerca 660 milhões dos projetos brasileiros. A Índia é o segundo país em número de projetos (9) e na utilização de recursos (cerca de 2,7 bilhões de dólares), ficando atrás somente da China.

Tabela 2: Projetos apresentados por países membros do BRICS

\begin{tabular}{|l|r|r|r|r|r|r|r|c|c|c|c|r|}
\hline \multicolumn{1}{|c|}{ País } & \multicolumn{1}{c|}{$1^{\mathrm{o}} \mathrm{P}}$. & $2^{\mathrm{o}} \mathrm{P}$. & $3^{\mathrm{o}} \mathrm{P}$. & $4^{\mathrm{o}} \mathrm{P}$. & $5^{\circ} \mathrm{P}$. & $6^{\mathrm{o}} \mathrm{P}$. & $7^{\mathrm{o}} \mathrm{P}$. & $8^{\circ} \mathrm{P}$. & $9^{\circ} \mathrm{P}$. & $10^{\circ} \mathrm{P}$. & $11^{\mathrm{o}} \mathrm{P}$. & Total \\
\hline Brasil & 300 & 50 & 71 & 200 & 40 & - & - & - & - & - & - & 661 \\
\hline Rússia & 100 & 460 & 68,8 & 320 & 220 & 300 & - & - & - & - & - & 1468,8 \\
\hline Índia & 250 & 350 & 470 & 345 & 350 & 175 & 350 & 260 & 224 & - & - & 2774 \\
\hline China & 81 & 298 & 300 & 200 & 300 & 300 & 289,8 & 608,4 & 400 & 300 & 119,5 & 3196,7 \\
\hline $\begin{array}{l}\text { África } \\
\text { do Sul }\end{array}$ & 180 & 200 & 300 & 480 & 221,2 & 79,5 & - & - & - & - & - & 1460,7 \\
\hline
\end{tabular}

Fonte: Elaboração própria com dados extraídos do sítio oficial do NBD em 03/06/2019.

$1^{\circ} \mathrm{P} .=1^{\circ}$ Projeto apresentado pelo país.

Valores dos empréstimos para os projetos em milhões de dólares.

Considerando apenas os membros fundadores, a estrutura institucional do NBD não fornece um poder estrutural para que alguns de seus agentes se sobressaiam em detrimento de outros, pois cada membro possui uma equivalente margem de atuação em relação aos demais, prevalecendo o poder dos agentes. Dos dados apresentados, o que se percebe é um interesse maior de China e Índia na apresentação de projetos de infraestrutura e utilização dos recursos do Banco, uma atuação intermediária de Rússia e África do Sul, bem como uma participação menor do Brasil. 


\subsection{Dimensão Método de Aplicação de Meios (soft power, hard power e smart power)}

Os conceitos de hard power, soft power e smart power são definidos pelo método de aplicação de meios de poder. Chega-se a proposição do período acima combinado as análises de Nye (2011) e Baldwin (2013) ${ }^{124}$. Como explicado no capítulo teórico, hard power não é totalmente coincidente com os meios militares ou econômicos de exercício de poder (pois é definido pela coerção e/ou pagamento), soft power não é totalmente coincidente com os meios institucionais e culturais (pois é definido pela atração e/ou persuasão). Por fim, smart power não é a soma dos meios militares, econômicos, culturais e institucionais, pois é definido pela utilização de uma estratégia conforme o contexto no qual os atores se inserem. Logo, é pelo método de aplicação dos meios de exercício de poder, e não pelos meios em si, que se define o poder hard, soft e smart. Fazem parte de um rol exemplificativo de métodos a coerção, o pagamento, a persuasão, a atração e a estratégia.

No Novo Banco de Desenvolvimento, se observam elementos para cada método de aplicação de meios de exercício de poder listado acima. O Banco possibilita hard power tanto pela coerção como pelo pagamento. O Acordo Constitutivo prevê possibilidades de inabilitação de membros, de medidas para suprir perdas do Banco e de suspensão de membros.

Conforme a alínea "a" do Art. 6 do Acordo, um membro é inabilitado quando não paga alguma parcela do montante correspondente à sua parte do capital social do Banco. A inabilitação do membro refere-se ao não exercício de sua capacidade de voto que corresponde à porcentagem da parcela devida, tendo por base o total a ser pago para a integralização de sua parte no capital social. A inabilitação permanece pelo tempo da duração da falta de cumprimento. De acordo com o inciso iii da alínea "b" do Art. 11, a inabilitação é aprovada pelo Conselho de Governadores, sem possibilidade de delegação da decisão para o Conselho de Diretores ${ }^{125}$.

No Art. 25 do Acordo Constitutivo estão as medidas para custear eventuais perdas do Banco. Em situação de inadimplência com relação a empréstimos realizados, o Banco poderá efetuar modificação nos termos dos empréstimos, com exceção à unidade

\footnotetext{
${ }^{124}$ Nye trata dos conceitos de hard power, soft power e smart power no livro The Future of Power (2011). Baldwin aborda as dimensões do poder, incluindo a dimensão meios de exercício de poder, no artigo Power and International Relations (2013).

${ }^{125}$ BRICS. Acordo Constitutivo sobre o Novo Banco de Desenvolvimento. 2014.
} 
monetária de pagamento. A cobertura de perdas poderá ocorrer com as provisões do Banco, a renda líquida, as reservas especiais, a reserva geral e excedentes, o capital integralizado sem obrigações, e por fim, com a quantidade de capital subscrito exigível não integralizado ${ }^{126}$.

Consoante o Art. 38 do Acordo Constitutivo do NBD, um membro pode ter a sua filiação ao Banco suspensa caso descumpra qualquer uma das suas obrigações com a instituição. A suspensão é aprovada mediante decisão do Conselho de Governadores, com maioria especial. $\mathrm{O}$ membro punido tem as suas atividades no Banco suspensas por um ano, contando da data da decisão que o suspendeu. O período de um ano pode ser reduzido por decisão do Conselho de Governadores, também por maioria especial. O membro punido não exerce nenhum direito regulamentado ou sujeito ao Acordo Constitutivo do Banco, com exceção ao direito de se retirar da instituição. No entanto, mesmo com a retirada, o país continua tendo que cumprir as suas obrigações pendentes ${ }^{127}$.

Além da coerção, o hard power no NBD também se manifesta com "pagamentos". Um dos principais propósitos do Banco é financiar projetos de desenvolvimento. Da data de início das operações do NBD em 03/07/2015 até 31/05/2019, os valores dos 37 projetos apresentados somam a quantia de USD 9,56 bilhões. Dos projetos propostos, os valores variam de USD 40 milhões (Sorocaba Mobility and Urban Development Project) até 608,4 milhões (Hohhot New Airport Project) ${ }^{128}$. É claro que os recursos do Banco são provenientes dos próprios países membros, no entanto, os serviços prestados pela instituição não se limitam a repasses de recursos, pois estes são acompanhados de assistência técnica para a elaboração e a execução dos projetos de infraestrutura ${ }^{129}$.

Deste modo, verifica-se que também há nas instituições hard power, e não apenas comunicação, troca de informações e cooperação. É uma evidência que um meio de exercício do poder, no caso institucional, pode ser utilizado de várias formas, incluindo o uso dos métodos de coerção e pagamento, típicos do hard power. No entanto, também se verifica a presença de soft power no Banco do BRICS.

O soft power é marcado pelos métodos de atração e persuasão. A atração do NBD é observada em alguns elementos nos quais a instituição se diferencia de muitas outras (Cooper, 2017), como: a presença do princípio da igualdade entre os seus membros

\footnotetext{
${ }^{126}$ BRICS. Acordo Constitutivo sobre o Novo Banco de Desenvolvimento. 2014.

127 Idem.

${ }^{128} \mathrm{https}$ ://www.ndb.int/projects/list-of-all-projects/ Acesso: 31/05/2019, às $21 \mathrm{~h} 01$.

${ }_{129}$ BRICS. Acordo Constitutivo sobre o Novo Banco de Desenvolvimento. 2014.
} 
fundadores, não observado em outras instituições financeiras (incluindo o AIIB); a promoção do desenvolvimento sustentável, com foco em fontes de energia renováveis; a velocidade das entregas dos projetos.

Na governança do Banco do BRICS (Suchodolski e Demeulemeester, 2018), as decisões são tomadas por maioria simples (em geral) e não há capacidade de veto. Sendo diferente do FMI, por exemplo, instituição na qual o Estados Unidos possui capacidade de veto. Também se visa o uso dos sistemas dos países membros do Banco. Trata-se de um aspecto de soberania nacional e de não-intervenção em assuntos políticos internos. Busca-se o respeito à soberania sobre as instituições e os regulamentos dos países membros. Ademais, sem a imposição de padrões externos, economiza-se tempo e diminui-se custos, evitando excesso de burocracia com trabalho em dois padrões. Há o fortalecimento das instituições locais nos desenvolvimentos dos projetos.

Além disso, o NBD tende a focar numa prática operacional nova para os seus projetos, com vistas ao desenvolvimento sustentável (Suchodolski e Demeulemeester, 2018). O conceito tradicional de sustentabilidade em projetos de infraestrutura busca minimizar externalidades negativas. $\mathrm{O}$ entendimento do NBD vai além da visão tradicional do conceito, havendo não apenas a intenção de mitigar danos, mas também de maximizar impactos positivos.

O modus operandi (Suchodolski e Demeulemeester, 2018) também envolve a velocidade de execução, que é almejada pelo Banco do BRICS, evitando o excesso de burocracia. Nos três anos primeiros anos de operação, o NBD aprovou 22 empréstimos, totalizando mais de 5,5 bilhões de dólares em seus países membros, estabelecendo parceria com mais de 20 organizações públicas e privadas. Esses números foram atingidos com cerca de 100 empregados, enquanto o Asian Development Bank possui mais de 3.500 empregados, e o IBRD mais de 10 mil.

O soft power também ocorre pelo método da persuasão (Nye, 2011), que envolve a tentativa de um ator convencer outros acerca de seus próprios argumentos, os quais podem ser publicizados. A diplomacia pública (Nye, 2008) é um instrumento que os governos utilizam para apresentar numa comunicação os seus argumentos e persuadir públicos de outros países, e não apenas os seus agentes estatais. A diplomacia pública visa chamar atenção para os seus argumentos através de transmissões diversas de conteúdo, por meio do cinema, da Internet e de outros meios de comunicação.

Para a análise da persuasão no contexto do NBD, não analisaremos o mérito dos argumentos (governança, sustentabilidade e velocidade de execução), mas sim como eles 
são transmitidos via a diplomacia pública do Banco. Conforme o Art. 14 do Acordo Constitutivo, o Banco publicará relatórios e fornecerá informações. De acordo com a alínea "a" do referido artigo, o Banco deve publicar anualmente um relatório acerca das condições de suas contas, bem como transmitir trimestralmente aos membros da instituição um balanço da situação financeira, com a demonstração dos resultados das operações realizadas $^{130}$.

Para exercer a sua diplomacia pública, o NBD possui um sítio oficial com diversos conteúdos tornados públicos. São divulgados os documentos essenciais da instituição, os relatórios anuais, a lista de todos os projetos de infraestrutura, os memorandos de entendimento, eventos, notícias, entre outros conteúdos. Dentre os documentos essenciais disponibilizados estão o Acordo Constitutivo, os acordos entre o NBD e os bancos de desenvolvimento dos países membros, os termos com as condições e os procedimentos para a admissão de novos membros e políticas diversas com diretrizes ${ }^{131}$.

Dentre as diretrizes apresentadas estão a política de assistência técnica, a política sobre empréstimos, as regras e os procedimentos do Conselho de Governadores e do Conselho de Diretores, a política sobre a parceria com o NBD, o framework social e ambiental, entre outros. Por exemplo, a assistência técnica envolve o auxílio para a formulação, identificação, implementação e operacionalização eficiente dos projetos financiados pelo Banco. As parcerias são formas de cooperação, como co-financiamento de projetos e compartilhamento de experiências por meio de publicações conjuntas, conferências e outros eventos. O framework social e ambiental objetiva a avaliação dos riscos e impactos dos projetos, de modo que seja assegurada a sustentabilidade ${ }^{132}$.

Os Relatórios Anuais de 2016, 2017 e 2018 abordam aspectos da governança do NBD, da promoção do desenvolvimento sustentável e dos resultados das operações. Acerca da governança, os três Relatórios discorrem a respeito do Conselho de Governadores e do Conselho de Diretores, demonstrando de forma equiparada a participação dos países membros, os quais contam com igual número de governadores e de diretores. No entanto, também há relatos específicos, como ocorreu no Relatório de 2016, o qual comentou sobre a assinatura do acordo que concluiu a escolha de Shangai como a cidade sede do Banco ${ }^{133}$. Já o Relatório de 2018 comentou sobre os escritórios

\footnotetext{
${ }^{130}$ BRICS. Acordo Constitutivo sobre o Novo Banco de Desenvolvimento. 2014.

131 https://www.ndb.int/ Acesso: 31/05/2019, às $21 \mathrm{~h} 01$.

132 Idem.

${ }^{133}$ Note-se que tal acordo de 2016 apenas concluiu a escolha de Shangai como cidade sede, uma vez que o Art. 3 do Acordo Constitutivo assinado em 2014 já definiu a cidade chinesa como sede.
} 
regionais do NBD. Até o fim de 2018, apenas o escrito regional em Johanesburgo (África do Sul) estava em funcionamento, sendo até então aguardadas as aberturas dos escritórios regionais em São Paulo (Brasil), Moscou (Rússia) e Nova Délhi (Índia) ${ }^{134}$.

Sobre a sustentabilidade, o Relatório de 2016 apresentou o contexto global com a aprovação dos ODS e do Acordo de Paris (COP21) em 2015, bem como a influência de tais eventos na fundação do Banco do BRICS. O Relatório de 2017 enfatizou as parcerias do NBD para o desenvolvimento sustentável, com a assinatura de memorandos de entendimento com diversas instituições financeiras em abril de 2017, quais sejam: Asian Infrastructure Investment Bank, Eurasian Development Bank, European Bank for Reconstruction and Development, European Investment Bank, International Investment Bank (todos disponibilizados no sítio do Banco). O Relatório de 2018 informou o aumento da colaboração com as Nações Unidas e as suas Agências Especializadas. Em dezembro de 2018, foi concedido ao NBD o status de observador da Assembleia Geral das Nações Unidas, com a intenção (oficial) de colaborar com o sistema ONU na promoção global do desenvolvimento sustentável ${ }^{135}$.

Acerca dos resultados das atividades do Banco, os Relatórios Anuais de 2016, 2017 e 2018 listam os projetos aprovados e valor dos empréstimos concedidos. O mais extenso, o Relatório de 2018, enfatizou o aumento das operações do NBD, de modo a ficar implícita uma velocidade na análise e na aprovação de projetos. Segundo o referido Relatório, foram sete empréstimos aprovados em 2016 (no valor total de USD 1,5 bilhão), seis empréstimos aprovados em 2017 (no valor total de USD 1,8 bilhão) e 17 empréstimos aprovados em 2018 (no valor total de USD 4,7 bilhões). É clara a intenção de demonstrar um aumento no interesse dos países membros pela instituição, bem como a alta capacidade financeira pelos vultosos valores emprestados ${ }^{136}$.

Por fim, o smart power é notado pela estratégia presente no NBD que leva em consideração o contexto global pela busca oficial por um desenvolvimento sustentável. A busca pela sustentabilidade pode ser mais formal do que prática, no entanto, é razoável o pressuposto que o desenvolvimento é no mínimo almejado pelos países não desenvolvidos. Conforme o Programa das Nações Unidas para o Desenvolvimento ${ }^{137}$, dos

\footnotetext{
${ }^{134}$ Relatório Anual do NBD de 2016, Relatório Anual do NBD de 2017 e Relatório Anual do NBD de 2018. ${ }^{135}$ Idem.

136 Idem.

137 http://www.br.undp.org/content/brazil/pt/home/idh0/rankings/idh-global.html Acesso: 29/07/2019, às $11 \mathrm{~h} 29$.
} 
188 países com dados disponíveis, apenas 49 possuem Índice de Desenvolvimento Humano (IDH) muito alto, sendo que 88 países possuem IDH médio ou baixo.

Logo, o NBD mostra-se como uma opção atrativa (a princípio) para dezenas de países do mundo, por ser um instrumento que pode contribuir para o financiamento de projetos de desenvolvimento. O status de observador do NBD na Assembleia Geral das Nações Unidas, que conta com 193 países, é útil para uma aproximação entre Banco e quase todos os países da comunidade internacional. A estratégia do BRICS presente no NBD, que leva em consideração um cenário global no qual a maioria dos países é renda média ou baixa, possibilita o aumento do domínio de poder do BRICS, isto é, a quantidade de atores envolvidos em suas relações de poder e em seus interesses.

\subsection{Dimensão Geográfica (poder terrestre, poder marítimo, poder aéreo e poder espacial)}

O entendimento do conceito de geopolítica é fundamental para a compreensão do poder geográfico. A geopolítica (Kelly, 2016) aborda as localizações dos países e dos recursos naturais e como tal disposição é capaz de influenciar as atuações dos agentes. São propriedades geográficas fatores como as posições dos países, suas extensões territoriais, seus relevos, as distâncias, entre outros. A partir de tal ótica é possível identificar conceitos de poder conforme os aspectos geográficos, sejam terrestres, marítimos, aéreos ou espaciais. Adotando a visão de Baldwin (2013), tais aspectos podem ser entendidos como recursos de poder, caso a análise seja anterior a uma relação entre atores, ou como meios pelos quais o poder foi exercido, caso a análise seja posterior a uma relação.

Entre os membros do BRICS estão quatro dos sete países com maior extensão territorial, Rússia $\left(1^{\circ}\right)$, China $\left(3^{\circ}\right)$, Brasil $\left(5^{\circ}\right)$ e Índia $\left(7^{\circ}\right)$. A África do Sul ocupa o $24^{\circ}$ $\operatorname{lugar}^{138}$. Uma maior extensão territorial implica num maior espaço aéreo e numa maior órbita geoestacionária. Segundo $o$ artigo $1^{\mathrm{o}}$ da Convenção sobre Aviação Civil Internacional (1944) ${ }^{139}$, cada Estado tem soberania sobre o espaço aéreo sobre o seu território. O mesmo não acontece com órbita geoestacionária. Conforme o Treaty on Principles Governing the Activities of States in the Exploration and Use of Outer Space,

\footnotetext{
138 Fonte: https://data.worldbank.org/indicator/AG.LND.TOTL.K2?view=chart Acesso: 30/06/2019, às $11 \mathrm{~h} 34$.

139 Disponível em: https://www.icao.int/publications/Documents/7300 cons.pdf Acesso: 30/06/2019, às $10 \mathrm{~h} 01$.
} 
including the Moon and Other Celestial Bodie (1967) ${ }^{140}$, o espaço sideral não é sujeito à apropriação ou reivindicação de soberania por parte dos Estados. Há um entendimento no Comitê das Nações Unidas para o Uso Pacífico do Espaço ${ }^{141}$ de que a órbita geoestacionária é parte do espaço sideral, não sendo sujeita a reivindicações de soberania. No entanto, há discordância como a demonstrada pela Declaração de Bogotá $(1976)^{142}$, na qual é alegado que a órbita geoestacionária é um recurso natural passível de exercício de soberania (porém, prevalece o entendimento geral de que não é).

Todos os integrantes do BRICS são banhados pelo mar, não havendo nenhum país landlocked entre eles. Quatro dos cinco membros estão entre os 20 com maiores litorais: Rússia $\left(4^{\circ}\right)$, China $\left(10^{\circ}\right)$, Brasil $\left(15^{\circ}\right)$ e Índia $\left(16^{\circ}\right)$. A África do Sul ocupa o $40^{\circ} \operatorname{lugar}^{143}$. Ademais, os membros do BRICS possuem proximidade com todos os oceanos: Brasil (Atlântico), Rússia (Atlântico, passando pelo Mar Báltico e o Mar do Norte ou passando pelo Mar Negro e o Mar Mediterrâneo; Glacial Ártico; Pacífico), Índia (Índico), China (Pacífico, passando pelo Mar da China Oriental ou pelo Mar do Sul da China), África do Sul (Atlântico; Índico; e proximidade com o Glacial Antártico - entre a Cidade do Cabo e o Oceano Glacial Antártico há apenas mar seguindo o meridiano na direção sul).

No entanto, o poder geográfico (seja terrestre, marítimo, aéreo ou espacial) não depende apenas de aspectos naturais. O espaço transformado é fundamental para a consolidação e a ampliação do poder fundado em elementos geográficos. A infraestrutura proporcionada por ferrovias, rodovias, aeroportos, portos, satélites fortalecem os recursos de poder baseado em aspectos geográficos, pois possibilita conexões e comunicações diversas para a sociedade, a economia e as forças armadas de um dado país. Já dizia Mackinder (1904): "trans-continental railways are now transmuting the conditions of land-power". Nesse sentido, o Banco do BRICS, ao financiar projetos de infraestrutura, contribui para o aumento do poder geográfico de seus membros.

Até 31/05/2019, o Brasil apresentou cinco projetos, com a participação da União, de dois Estados e de um Município. A proposta Financing of Renewable Energy Projects and Associated Transmission (de USD 300 milhões) foi apresentada pela União (por meio

\footnotetext{
${ }^{140}$ Disponível em: http://www.unoosa.org/pdf/gares/ARES 21 2222E.pdf Acesso: 30/06/2019, às 10h51.

${ }^{141}$ Report of the Legal Subcommittee on its fifty-seventh session, held in Vienna from 9 to 20 April 2018. Disponível em: https://undocs.org/A/AC.105/1177 Acesso: 30/06/2019, às 10h57.

142 Disponível em: http://www.jaxa.jp/library/space law/chapter 2/2-2-1-2 e.html Acesso: 30/06/2019, às 11h15. A Declaração de Bogotá foi assinada no Primeiro Encontro de Países Equatoriais: Brasil, Colômbia, Congo, Equador, Indonésia, Quênia, Uganda e Zaire (atual República Democrática do Congo).

143 Fonte: https://www.cia.gov/library/publications/the-world-factbook/fields/282.html Acesso:
} $30 / 06 / 2019$, às $11 \mathrm{~h} 35$. 
da empresa pública BNDES) e visa repassar os empréstimos do NBD para projetos de energia renovável. A proposta Environmental Protection Project (de USD 200 milhões) foi apresentada pela União (por meio da sociedade de economia mista Petrobrás) e objetiva a atualização da infraestrutura e de equipamentos de duas refinarias: Refinaria Duque de Caxias - REDUC (Município de Duque de Caixas no Estado do Rio de Janeiro), e Refinaria Gabriel Passos - REGAP (Município de Betim no Estado de Minas Gerais). A intenção é melhorar a performance ambiental da companhia. A proposta Pará Sustainable Municipalities Project (de USD 50 milhões) foi apresentada pelo Estado do Pará e tem por finalidade a pavimentação de 186 quilômetros de estrada de terra, a construção de cinco locais de eliminação de resíduos, bem como extensão da conectividade de Internet por fibra óptica por 1000 quilômetros. A proposta Maranhão Road Corridor - South North Integration (de USD 71 milhões) foi apresentada pelo Estado do Maranhão e tem por propósito a reconstrução de 233 quilômetros da rodovia estadual norte-sul MA-006. Trata-se de uma alto-estrada que conecta a região produtora de grãos no sul do Maranhão até o porto de Itaqui, no norte do Estado. A proposta Develop Sorocaba - Sorocaba Mobility and Urban Development Project (de USD 40 milhões) foi apresentada pelo Município de Sorocaba/SP e visa a reforma de ruas com pavimentação e construção de ciclovias, além da inclusão de sistemas de drenagem ${ }^{144}$.

O poder terrestre é o mais abordado pelos projetos brasileiros. A proposta de Sorocaba é mais modesta, no entanto, os projetos do Maranhão e do Pará possuem envergadura considerável pelos quilômetros de rodovia a serem construídos ou reformados, sendo relevante para a conectividade em regiões com menor infraestrutura. O poder marítimo é reforçado pelo projeto do Maranhão, pois a alto-estrada a ser construída liga o interior do Estado ao Porto de Itaqui. Com um maior escoamento de produção, aumentarão as atividades do referido Porto. Uma infraestrutura portuária ativa é fundamental para o poder marítimo de uma país. O poder aéreo e o poder espacial não receberam atenção das propostas brasileiras.

O poder cibernético (Nye, 2011) é baseado na eletrônica e computação. Trata-se de um poder que não é propriamente geográfico, pois o "espaço" em questão é "virtual" (não terrestre, marítimo, aéreo ou espacial). No entanto, modificações no espaço geográfico são necessárias para o acesso ao ambiente cibernético. Nesse sentido, a extensão de cabos de fibra óptica a serem construídas no Pará contribuem para o poder

${ }^{144}$ https://www.ndb.int/projects/list-of-all-projects/ Acesso: 31/05/2019, ás 21 h01. 
cibernético do Brasil, ao proporcionar acesso à Internet em uma região distante dos locais mais populosos do país.

Até o final de maio de 2019, a Rússia apresentou seis projetos, sendo cada proposta com um setor alvo (target sector) diferente. A proposta Two Loans to EDB and IIB for Nord-Hydro (de USD 100 milhões, setor alvo: Energia Limpa) visa a construção de uma pequena barragem e duas hidroelétricas para fornecimento de fornecimento de energia renovável para a região da Karelia. A proposta Judicial System Support Project (de USD 460 milhões, setor alvo: Infraestrutura Social) objetiva atualizar a infraestrutura física e integrar o sistema de tecnologia da informação e comunicação do judiciário russo. A proposta Ufa Eastern Exit Project (de USD 68,8 milhões, setor alvo: Transporte) tem por finalidade a construção de um corredor de transporte na cidade de Ufa, 1,2 km de túnel, 2,5 km de ponte e 10,2 km de rodovia. A proposta Volga (de USD 320 milhões, setor alvo: Água, Saneamento e Proteção contra Inundações) visa a modernização e a construção de sistemas integrados de abastecimento de água e saneamento para cinco cidades na bacia do rio Volga. A proposta Small Historic Cities Development Project (de USD 220 milhões, setor alvo: Infraestrutura Urbana) tem por propósito a conservação de patrimônios culturais urbanos de pequenas cidades históricas na Rússia. A proposta Sustainable infrastructure in relation to "ZapSibNefteKhim" Project (de USD 300 milhões, setor alvo: Proteção Ambiental) objetiva aumentar a segurança ambiental no complexo petroquímico ZapSibNefteKhim, no qual há produção da substância química poliolefinas $^{145}$.

A Rússia, apesar de ter proposto apenas seis projetos ao NBD, aproveita bem as possibilidades de aprimoramento da infraestrutura de seu território, explorando todos os seis setores alvos existentes na categorização estabelecida pelo Banco. As propostas russas variam desde o saneamento básico do projeto Volga até ao uso de tecnologia da informação no projeto para modernização da justiça russa. Os temas também são bem variados, incluindo tanto turismo como indústria química.

O poder terrestre é contemplado com a construção de uma rodovia em Ufa, acompanhada de um túnel e uma ponte. Nenhum dos projetos se enquadrariam diretamente num aprimoramento dos poderes aéreo e espacial. A utilização para abastecimento das águas do maior rio da Rússia (o Volga) e a construção de hidroelétricas na região da Karelia não são propriamente coincidentes com o poder marítimo, mas

${ }^{145}$ https://www.ndb.int/projects/list-of-all-projects/ Acesso: 31/05/2019, às $21 \mathrm{~h} 01$. 
significam um maior aproveitamento dos recursos hídricos do país. Nesse ponto, cabe uma crítica a teoria acerca do poder marítimo, para questionar em que medida elementos fluviais se enquadrariam no conceito de poder marítimo. Talvez fosse mais apropriado adaptar a expressão "poder marítimo" para incluir outros elementos hídricos de um país, como rios e lençóis freáticos. Por fim, o poder cibernético é observado com o desenvolvimento de tecnologia da informação para o judiciário da Rússia.

Até 31/05/2019, a Índia apresentou nove projetos ao NBD. Diferentemente da Rússia, há um foco num setor alvo específico, o de Transporte. A proposta Assam Bridge Project (de USD 224 milhões) visa a construção de uma ponte, com seis faixas de rodovia ao longo de aproximadamente oito quilômetros, na cidade de Guwahati (Estado de Assam). A proposta Mumbai Metro Rail Project (de USD 260 milhões) objetiva a construção de três linhas de metrô na cidade de Mumbai, totalizando cerca de 58 quilômetros. A proposta Madhya Pradesh Major District Roads II Project (de USD 350 milhões) visa aumentar a conectividade das rodovias no Estado de Madhya Pradesh. A proposta Madhya Pradesh Bridges Project (de USD 350 milhões) tem por finalidade a construção ou reforma de 380 pontes no Estado de Madhya Pradesh, que variam de oito a 780 metros de cumprimento, tanto sobre riachos menores como sobre rios maiores. A proposta Bihar Rural Roads Project (de USD 350 milhões) tem por propósito a construção ou reforma de quatro mil quilômetros de rodovia, ao longo de 26 distritos no Estado de Bihar $^{146}$.

Há outros quatros projetos apresentados pela Índia. A proposta Canara Renewable Energy Financing Scheme (de USD 250 milhões) visa apoiar o financiamento de energia renovável por meio do Esquema de Financiamento de Energia Renovável, estabelecido pelo Canara Bank, incluindo energia eólica, energia solar, pequena energia hidrelétrica, energia de biomassa, energia geotérmica, entre outras. A proposta Madhya Pradesh Major District Roads Project (de USD 350 milhões) objetiva a reforma de 1500 quilômetros de estrada no Estado de Madhya Pradesh. A proposta Madhya Pradesh Multi Village Water Supply Project (de USD 470 milhões) tem por finalidade o fornecimento de água potável encanada para as áreas rurais do Estado de Madhya Pradesh. A proposta Rajasthan Water Sector Restructuring Project (de USD 345 milhões) tem por propósito a reforma o sistema do Canal Indira Gandhi (Estado de Rajasthan) para evitar infiltrações, conservar a água e melhorar a eficiência do uso da água ${ }^{147}$.

\footnotetext{
${ }^{146} \mathrm{https} / / / \mathrm{www} . \mathrm{ndb}$. int/projects/list-of-all-projects/ Acesso: 31/05/2019, às $21 \mathrm{~h} 01$.
}

${ }^{147} \mathrm{Idem}$. 
Percebe-se uma relevância atribuída às pontes em dois projetos de infraestrutura indianos que possuem como foco o transporte. Além da importância econômica das pontes (com o transporte de mercadorias) e social (com a mobilidade de pessoas), tais construções são fundamentais para eventual deslocamento de tropas. Por exemplo, durante a Segunda Guerra Mundial, a Operação Market Garden (US Army, 1977) teve por finalidade a captura de pontes sobre o rio Reno, então sob o domínio do exército alemão. A captura intacta das pontes era necessária para o deslocamento das forças aliadas em direção à Alemanha. Índia e Paquistão entraram em conflito armado quatros vezes no século XX, em décadas diferentes $\left(1947,1965,1971\right.$ e 1999) ${ }^{148}$. Num eventual novo conflito entre os dois países, é importante para a Índia ter as 380 pontes a serem construídas no Estado de Madhya Pradesh (localizado em posição central na Índia), proporcionando o transporte de tropas pelo país, de sul a norte e de leste a oeste.

O poder terrestre indiano é reforçado pela construção de pontes nos Estados de Madhya Pradesh e de Assam, bem como pela construção e reforma de rodovia nos Estados de Madhya Pradesh e de Bihar. O poder marítimo não é propriamente abordado pelos projetos indianos, no entanto, a busca de um melhor aproveitamento dos recursos hídricos do país está presente na proposta de reforma do Canal Indira Gandhi no Estado de Rajasthan, bem como no projeto para fornecimento de água potável em zonas rurais em Madhya Pradesh. Por fim, os poderes aéreo, espacial e cibernético não são diretamente abordados pelas propostas da Índia.

A China apresentou 11 projetos até o final de maio de 2019. A proposta Lingang Distributed Solar Power Project (de USD 81 milhões) visa a redução da emissão de carbono utilizando a tecnologia de energia solar fotovoltaica em telhados na Área Industrial de Xangai Lingang. A proposta Putian Pinghai Bay Offshore Wind Power Project (de USD 298 milhões) objetiva aumentar a capacidade de energia eólica offshore na baía de Putian Pinghai, para fornecer eletricidade à província de Fujian. A proposta Hunan Ecological Development Project (de USD 300 milhões) tem por finalidade melhorar a qualidade da água e o controle de enchentes na Área do Coração Verde de Hunan, bem como reabilitar cursos de rios e melhorar o tratamento de esgoto na bacia hidrográfica do rio Xiang. A proposta Jiangxi Industrial Low Carbon Restructuring and Green Development Pilot Project (de USD 200 milhões) visa a conservação de energia, a redução de resíduos e de emissão de poluentes, aumentando a reutilização industrial da

\footnotetext{
${ }^{148}$ Fonte: https://www.dw.com/pt-br/hist \%C3\%B3rico-da-rela\%C3\%A7\%C3\%A3o-entre-\%C3\%ADndiae-paquist $\% \mathrm{C} 3 \% \mathrm{~A} 3 \mathrm{o} / \mathrm{a}-47717117$ Acesso: 06/07/2019, às $11 \mathrm{~h} 39$.
} 
água na província de Jiangxi. A proposta Chongqing Small Cities Sustainable Development Project (de USD 300 milhões) objetiva melhorar a mobilidade urbana e a restauração ambiental, especialmente em áreas de frente de água, no município de Chongqing $^{149}$.

A proposta Luoyang Metro Project (de USD 300 milhões) tem por finalidade a construção da primeira linha ferroviária urbana da cidade de Luoyang. A proposta Hohhot New Airport Project (de USD 608,4 milhões) tem por propósito a construção de um aeroporto na cidade de Hohhot. A proposta Jiangxi Natural Gas Transmission System Development Project (de USD 400 milhões) visa a construção de um sistema de fornecimento de gás natural para a província de Jiangxi. A proposta Guangdong Yudean Yangjiang Shapa Offshore Wind Power Project (de USD 289,8 milhões) objetiva a construção de um parque eólico offshore, na área de águas rasas da cidade de Yangjiang, para melhorar a estrutura energética da província de Guangdong. A proposta Chongzuo Water Resource Rehabilitation and Ecological Conservation Project (de USD 300 milhões) tem por finalidade a construção de estações de drenagem e zonas de proteção vegetal em áreas adjacentes às aguas de rios e lagos, na cidade de Chongzuo. A proposta Zhejiang Green Urban Project - Shengzhou Urban and Rural Integrated Water Supply and Sanitation Project Phase II (de USD 119,5 milhões) visa a construção de quatro estações de tratamento de água e três estações de tratamento de esgoto no município de Shengzhou ${ }^{150}$.

O poder aéreo é presente na proposta de construção de um aeroporto na cidade de Hohhot, aumentando a capacidade de voos e de utilização do espaço aéreo do país. O poder terrestre figura no projeto de construção de uma linha férrea na cidade de Luoyang. O poder marítimo está de certa forma presente nas propostas de construção de parques eólicos offshore na baía de Putian Pinghai e na cidade de Yangjiang, com uma maior utilização do espaço marítimo do país. Um melhor aproveitamento dos recursos hídricos chineses também estão presentes nos projetos para as cidades Chongzuo e Shengzhou, bem como para a província de Lingang e Hunan. Por fim, os poderes espacial e cibernético não são abordados diretamente nos projetos da China.

A África do Sul apresentou seis projetos até 31/05/2019. A proposta Project Finance Facility for Eskom (de USD 180 milhões) visa a construção de linhas de transmissão de energia para as áreas de Soweto e Ankerlig-Sterrekus. A proposta Durban

\footnotetext{
149 https://www.ndb.int/projects/list-of-all-projects/ Acesso: 31/05/2019, às $21 \mathrm{~h} 01$.
}

${ }^{150}$ Idem. 
Container Terminal Berth Reconstruction Project (de USD 200 milhões) objetiva a reforma da uma infraestrutura marítima e terrestre do Terminal de Contêineres de Durban, de modo a permitir que o Porto de Durban receba embarcações maiores (com capacidade de arqueação bruta superior a 100.000 toneladas). A Proposta Greenhouse Gas Emissions Reduction and Energy Sector Development Project (de USD 300 milhões) tem por finalidade a redução das emissões de dióxido de carbono (CO2) na África do Sul por meio de locais de produção de energia eólica, solar e de biomassa. A proposta Environmental Protection Project For Medupi Thermal Power Plant (de USD 480 milhões) tem por propósito a redução da emissão de dióxido de enxofre (SO2) da usina termoelétrica a carvão Medupi, através da construção de seis unidades de dessulfurização de gases de combustão, juntamente com instalações auxiliares. A proposta Lesotho Highlands Water Project Phase II (de USD 221,2 milhões) visa aumentar o abastecimento de água na bacia do rio Vaal transferindo água do Lesoto para a África do Sul, por meio da construção do túnel de barragem e transferência de água no território de Lesoto. A proposta Renewable Energy Sector Development Project (de USD 79,5 milhões) objetiva reduzir as emissões de CO2 na África do Sul, através do repasse de recursos para subprojetos nos setores de energia solar, biomassa e energia eólica ${ }^{151}$.

Os poderes terrestre e marítimo são abordados no projeto de Durban, com a reforma da infraestrutura marítima e terrestre do Porto da cidade. Também há uma intenção em utilizar mais os recursos hídricos por meio da construção do túnel de barragem na bacia do rio Vaal. Os poderes aéreo, espacial e cibernético não são diretamente envolvidos nas propostas sul-africanas. Os demais projetos se voltam para a questão energética, seja para transmissão (para as áreas de Soweto e Ankerlig-Sterrekus) ou para produção de energia limpa (como na usina de Medupi).

Nenhum dos membros do BRICS apresentou um projeto tocante a infraestrutura espacial, a qual poderia ser abordado com a construção de satélites e de bases de lançamentos de foguetes, por exemplo. O poder cibernético é utilizado de maneira regionalizada num projeto brasileiro (com cabos de fibra óptica no norte do país) e de forma mais abrangentes numa proposta russa (com um sistema de tecnologia da informação para o judiciário nacional). Apenas a China conferiu atenção ao poder aéreo, com o interesse na construção de um aeroporto. O poder terrestre é considerado por todos os integrantes do BRICS em pelo menos um projeto de cada membro, sendo a Índia o

\footnotetext{
${ }^{151}$ https://www.ndb.int/projects/list-of-all-projects/ Acesso: 31/05/2019, às $21 \mathrm{~h} 01$.
} 
país que atribuiu maior relevância à tal poder em suas propostas de construção de rodovias e pontes. O poder marítimo é mais abordado pela China, mesmo numa perspectiva ampliada do conceito, incluindo um maior aproveitamento de recursos hídricos em geral. O poder marítimo chinês é ampliado com uma maior utilização de seu território marítimo, com parques eólicos offshore. Por fim, a África do Sul é o único membro do BRICS que apresentou uma proposta que envolve o território de país não membro, qual seja, o Lesoto (presente num projeto de transferência de água para abastecimento do rio Vaal, em leito sul-africano).

\subsection{Dimensão Incidência do Poder (direta e indireta)}

Quanto à incidência, o poder opera de forma direta ou indireta. Conforme Barnett e Duvall (2005), o poder atua de modo imediato na ocorrência direta, numa dada relação específica entre atores. $\mathrm{Na}$ ocorrência indireta, o poder atua à distância, seja espacial ou temporal, não existindo uma relação direta e específica entre os agentes. $\mathrm{O}$ meio institucional de exercício de poder é geralmente relacional e indireto, pois o poder numa instituição frequentemente opera através da interação entre atores (elemento relacional) e sem efeitos imediatos (elemento indireto). A diplomacia pública também é um exemplo de atuação indireta do poder, pois os seus efeitos difusos levam tempo para serem produzidos.

O NBD é uma instituição que realiza diplomacia pública, logo, há presença de duas características próprias da incidência indireta do poder. Não apenas através do Banco, mas o próprio BRICS, de maneira geral, pratica a diplomacia pública. É claro que também há os encontros fechados de gabinete, não divulgados à imprensa. No entanto, ocorrem muitos casos de diplomacia ostensiva, por exemplo, as reuniões televisionadas (como o encontro informal entre os Chefes de Estado às margens da Cúpula do G20 em Osaka de 2019 ${ }^{152}$ ), os comunicados formalizados por escrito à imprensa (como a declaração do encontro dos Ministros de Relações Exteriores às margens $73^{a}$ sessão da Assembleia Geral das Nações Unidas em $2018^{153}$ ), além de dezenas de documentos tornados públicos nos sítios eletrônicos do BRICS.

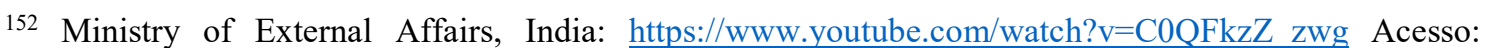
$01 / 08 / 2019$, às $10 \mathrm{~h} 49$.

153 Ministry of External Affairs, India: https://mea.gov.in/bilateraldocuments.htm?dtl/30442/Media_Statement_on_Meeting_of_BRICS_Ministers_of_Foreign_Affairs_Inte rnational Relations Acesso: 01/08/2019, às $11 \mathrm{~h} 01$. 
Apesar do memorando de entendimento para a criação de um sítio web conjunto do BRICS assinado em $2015^{154}$, o grupo continua com sítios anuais mantidos pelo país que exerce a presidência Pró-Tempore. A presidência foi exercida pela Índia em 2016 (http://brics2016.gov.in), pela China em 2017 (https://www.brics2017.org/English/), pela África do Sul em 2018 (http:/www.brics2018.org.za/) e pelo Brasil em 2019 (http://brics2019.itamaraty.gov.br/). O BRICS Business Council também possui o seu próprio sítio, mantido pela Índia: https://www.bricsbusinesscouncil.in/. Trata-se de um Conselho criado durante a V Cúpula do BRICS em 2013, na cidade de Durban na África do Sul, para fortalecer os laços de comércio e investimentos entre as comunidades empresariais dos países membros do BRICS. Entre os documentos tornados públicos estão as Declarações de Cúpula, os planos de ação temáticos (como o para cooperação e inovação ${ }^{155}$ ), declarações de encontros interministeriais, notícias diversas (incluindo sobre o encontro de sherpas ${ }^{156}$ ), fotos e vídeos dos vários eventos no âmbito do BRICS, entre outros.

Os elementos da diplomacia pública listados acima relacionam-se com o soft power. A atração e a persuasão do soft power do BRICS levam tempo para a produção de efeitos, mas tais efeitos ocorrem e de maneira indireta. De 2008 a 2019, no BRICS houve apenas a inclusão de um novo membro, a África do Sul. No entanto, 12 países já manifestaram interesse em aderir ao BRICS como membro pleno, quais sejam: Afeganistão, Argentina, Indonésia, México, Turquia, Egito, Irã, Nigéria, Sudão, Síria, Bangladesh e Grécia (Urio, 2019). Como tal interesse é em se tornar membro pleno do BRICS, depreende-se que existem também a intenção de aderir ao NBD. Logo, a incidência indireta do soft power do BRICS, de maneira geral, também se aplica ao Banco.

Deste modo, é indireta a incidência do poder na dimensão grau de transição no contexto do Banco do BRICS, porque apesar da demonstração de interesse de outros países, ainda não houve novas adesões, o que pode levar tempo devido à duração dos processos de negociações. Conforme o tópico grau de transição do poder, o NBD apresenta elementos tanto de power shift como de power remain. No power shift do NBD está presente a ideia de International Institutional Bypass (Stuenkel, 2017b), segundo a

\footnotetext{
${ }^{154}$ BRICS. Memorando de Entendimento sobre a Criação de um Sítio Web Conjunto do BRICS. 2015. 155 https://www.brics2017.org/English/Headlines/201708/t20170804_1764.html Acesso: 01/08/2019, às $11 \mathrm{~h} 28$. ${ }^{156}$ https://www.brics2017.org/English/China2017/Sherpas/ Acesso: 01/08/2019, às 11h28.
} 
qual o Banco do BRICS é um exemplo da prática do multilateralismo competitivo, por ser uma instituição que oferece algo diferente e complementar ao ofertado pelas instituições pré-existentes, ao mesmo tempo em que se beneficia das experiências de tais instituições mais antigas. A não adesão de novos membros ao NBD, em seus primeiros anos de funcionamento, é uma evidência de que não são imediatos os efeitos da criação da instituição no multilateralismo competitivo da política internacional.

Também é indireta a incidência do poder, tanto do BRICS (em geral) como do NBD (em específico), quanto a dimensão domínio, isto é, a quanto ao número de atores envolvidos em suas relações de poder. Para Lissovolik (2017), o BRICS+Circle tem o potencial de funcionar como uma plataforma agregadora de interesses, servindo de base para diferentes acordos, como de comércio e investimentos. Entretanto, o referido potencial, caso se concretize, não necessariamente será imediato, podendo demorar anos para que surtam efeitos concretos na política internacional, bem como para os atores envolvidos. Mais especificamente, o NBD contribui para o BRICS + Circle com os memorandos de entendimento que firmou com mais de dez instituições financeiras internacionais, incluindo o International Bank for Reconstruction and Development e o Asian Infrastructure Investment Bank ${ }^{157}$. Apesar disso, os efeitos concretos de tais normas também tendem não produzir resultados imediatos. Ademais, há uma enorme discussão na Ciência Política a qual busca analisar em que medida as normas institucionais afetam ou não o comportamento dos atores (Hall e Taylor, 2003). As instituições importam, entretanto, a sua relevância e seus impactos variam conforme o contexto.

Na dimensão geográfica, também é indireta a incidência do poder proporcionada pelos projetos do NBD. As durações das execuções dos projetos são medidas em anos. Além disso, não são imediatos os impactos dos resultados das obras ${ }^{158}$ nos poderes terrestre, marítimo e aéreo dos países membros do BRICS. Segue abaixo a tabela com os dados de durações dos projetos:

\footnotetext{
${ }^{157}$ Fonte: https://www.ndb.int/partnerships/agreements-memoranda/ Acesso: 13/06/2019 às $21 \mathrm{~h} 41$.

158 Diferentemente dos impactos das obras, há o impacto dos empréstimos contratados. A partir da assinatura, há uma conexão entre as partes, que contribui para o power shift, de modo que o país tomador do empréstimo aumento os seus vínculos com o NBD, uma instituição não patrocinada pelo Estados Unidos.
} 
Tabela 3: Tempo de Duração dos Projetos

\begin{tabular}{|c|c|c|}
\hline Projeto & País & Tempo estimado de duração \\
\hline $\begin{array}{l}\text { Lingang Distributed Solar Power } \\
\text { Project }\end{array}$ & China & $3 \operatorname{anos}(2017-2019)$ \\
\hline $\begin{array}{l}\text { Two Loans to EDB and IIB for Nord- } \\
\text { Hydro }\end{array}$ & Rússia & mais de 3 anos \\
\hline $\begin{array}{l}\text { Madhya Pradesh Major District Roads } \\
\text { Project }\end{array}$ & Índia & mais de 4 anos \\
\hline $\begin{array}{l}\text { Putian Pinghai Bay Offshore Wind } \\
\text { Power Project }\end{array}$ & China & mais de 3 anos \\
\hline Hunan Ecological Development Project & China & mais de 3,5 anos \\
\hline $\begin{array}{l}\text { Jiangxi Industrial Low Carbon } \\
\text { Restructuring and Green Development } \\
\text { Pilot Project }\end{array}$ & China & mais de 4 anos \\
\hline Judicial System Support Project & Rússia & mais de 5 anos (2018-2022) \\
\hline $\begin{array}{l}\text { Rajasthan Water Sector Restructuring } \\
\text { Project }\end{array}$ & Índia & mais de 5 anos \\
\hline Ufa Eastern Exit Project & Rússia & mais de 4 anos \\
\hline Volga & Rússia & 6 anos $(2019-2024)$ \\
\hline $\begin{array}{l}\text { Small Historic Cities Development } \\
\text { Project }\end{array}$ & Rússia & 7 anos $(2018-2024)$ \\
\hline $\begin{array}{l}\text { Durban Container Terminal Berth } \\
\text { Reconstruction Project }\end{array}$ & $\begin{array}{l}\text { África do } \\
\text { Sul }\end{array}$ & 9 anos $(2018-2026)$ \\
\hline Pará Sustainable Municipalities Project & Brasil & mais de 3 anos (2018-2021) \\
\hline $\begin{array}{l}\text { Maranhão Road Corridor - South North } \\
\text { Integration }\end{array}$ & Brasil & mais de 4 anos (2019-2022) \\
\hline $\begin{array}{l}\text { Chongqing Small Cities Sustainable } \\
\text { Development Project }\end{array}$ & China & 6 anos $(2018-2023)$ \\
\hline Bihar Rural Roads Project & Índia & mais de 5 anos (2018-2022) \\
\hline Luoyang Metro Project & China & 5 anos $(2017-2021)$ \\
\hline $\begin{array}{l}\text { Greenhouse Gas Emissions Reduction } \\
\text { and Energy Sector Development Project }\end{array}$ & $\begin{array}{l}\text { África do } \\
\text { Sul }\end{array}$ & mais de 15 anos (2018-2033) \\
\hline Environmental Protection Project & Brasil & mais de 6 anos (2016-2021) \\
\hline
\end{tabular}




\begin{tabular}{|c|c|c|}
\hline Madhya Pradesh Bridges Project & Índia & mais de 6 anos \\
\hline $\begin{array}{l}\text { Madhya Pradesh Major District Roads } \\
\text { II Project }\end{array}$ & Índia & mais de 5 anos \\
\hline $\begin{array}{l}\text { Guangdong Yudean Yangjiang Shapa } \\
\text { Offshore Wind Power Project }\end{array}$ & China & mais de 3 anos \\
\hline Hohhot New Airport Project & China & mais de 5 anos \\
\hline $\begin{array}{l}\text { Jiangxi Natural Gas Transmission } \\
\text { System Development Project }\end{array}$ & China & mais de 5 anos \\
\hline Mumbai Metro Rail Project & Índia & $5 \operatorname{anos}(2018-2022)$ \\
\hline $\begin{array}{lrr}\text { Chongzuo Water } & \text { Resource } \\
\text { Rehabilitation and } & \text { Ecological } \\
\text { Conservation Project } & \end{array}$ & China & mais de 5 anos \\
\hline $\begin{array}{l}\text { Environmental Protection Project For } \\
\text { Medupi Thermal Power Plant }\end{array}$ & $\begin{array}{l}\text { África do } \\
\text { Sul }\end{array}$ & mais de 7 anos \\
\hline $\begin{array}{l}\text { Lesotho Highlands Water Project Phase } \\
\text { II }\end{array}$ & $\begin{array}{l}\text { África do } \\
\text { Sul }\end{array}$ & mais de 6 anos \\
\hline $\begin{array}{l}\text { Renewable Energy Sector Development } \\
\text { Project }\end{array}$ & $\begin{array}{l}\text { África do } \\
\text { Sul }\end{array}$ & 5 anos $(2019-2023)$ \\
\hline $\begin{array}{l}\text { Zhejiang Green Urban Project - } \\
\text { Shengzhou Urban and Rural Integrated } \\
\text { Water Supply and Sanitation Project } \\
\text { Phase II }\end{array}$ & China & mais de 5 anos \\
\hline Assam Bridge Project & Índia & mais de 4 anos \\
\hline
\end{tabular}

Fonte: Elaboração própria com dados extraídos do sítio oficial do NBD.

Até 31/05/2019, foram 37 projetos propostos pelos países membros do NBD, sendo que 35 já tinham sido aprovados. Destes 35 projetos, 31 indicam o tempo de duração (todos acima listados). Ao todo, 20 dos 31 projetos com indicação de tempo possuem duração de 5 anos ou mais. As três propostas com maior duração são sulafricanas, quais sejam, Environmental Protection Project For Medupi Thermal Power Plant (mais de 7 anos), Durban Container Terminal Berth Reconstruction Project (9 anos) e Greenhouse Gas Emissions Reduction and Energy Sector Development Project (mais de 15 anos, com término previsto para 2033). A proposta chinesa Lingang 
Distributed Solar Power Project é a de menor duração e a única com apenas três anos de execução ${ }^{159}$.

Os dados acima evidenciam que os impactos do NBD possuem incidência indireta tanto para a dimensão geográfica do poder como para o desenvolvimento dos países. As infraestruturas a serem construídas levam de 3 a mais de 15 anos para ficarem prontas. Não há efeitos imediatos das obras, independentemente de a definição temporal do termo "imediato" ser em dias, semanas ou meses. Os benefícios das pontes, rodovias, ferrovias, aeroportos a serem construídos não serão usufruídos até o final da segunda década do século XXI.

No entanto, percebe-se no NBD alguns pontos específicos nos quais há incidência direta do poder. Por exemplo, o hard power presente na possibilidade de suspensão de um membro (Art. 38 do Acordo Constitutivo) possui efeitos diretos (imediatos). De maneira análoga, foi imediata a suspensão da Venezuela do processo de integração do Mercosul, bastando uma decisão dos demais membros (com fundamento no Protocolo de Ushuaia, que contêm a cláusula democrática) ${ }^{160}$.

Outro aspecto do NBD com incidência direta são os custos financeiros da instituição. Anualmente, todos os membros do BRICS vêm contribuindo com centenas de milhares de dólares para o capital social subscrito do Banco. Somente no ano de 2017, nenhum membro contribuiu com menos de 300 milhões de dólares para a instituição ${ }^{161}$.

Entretanto, nem todos os custos são imediatos. Alguns projetos do NBD possuem parcelamentos de pagamento que superam 10 anos. A proposta Lingang Distributed Solar Power Project (de USD 81 milhões) deverá ser paga em 28 parcelas ao longo de 14 anos. A proposta Hunan Ecological Development Project (de USD 300 milhões) deverá ser paga em 32 parcelas ao longo de 16 anos. A proposta Jiangxi Industrial Low Carbon Restructuring and Green Development Pilot Project (de USD 200 milhões) deverá ser paga em 34 parcelas ao longo de $17 \operatorname{anos}^{162}$.

De maneira geral, as dinâmicas do poder envolvendo o NBD se manifestam mais com incidência indireta do que com incidência direta. No entanto, a princípio os efeitos não imediatos do poder não são menos nem mais relevantes do que os efeitos imediatos. O planejamento dos atores (Chiavenato, 2014) pode ser tanto estratégico (de longo prazo),

\footnotetext{
159 https://www.ndb.int/projects/list-of-all-projects/ Acesso: 31/05/2019, às 21h01.

160 https://www.mercosur.int/pt-br/decisao-sobre-a-suspensao-da-republica-bolivariana-da-venezuela-nomercosul/ Acesso: 05/08/2019, às 22h41.

${ }_{161}$ Relatório Anual do NBD de 2017.

162 https://www.ndb.int/projects/list-of-all-projects/ Acesso: 31/05/2019, às $21 \mathrm{~h} 01$.
} 
tático (de médio prazo) e operacional (de curto prazo), sendo todos importantes para o alcance dos seus objetivos.

\subsection{Dimensão Grau de Dominância (power over, power with, power to)}

O poder se manifesta de diferentes formas numa relação entre atores, conforme o grau de dominância nela presente. Power over (Berger, 2005) indica um modelo tradicional de dominância, no qual a tomada de decisão é marcada pelo controle, pelo auto-interesse e pela instrumentalidade. Power with refere-se a um modelo de empoderamento, com a existência de diálogo, negociação, inclusão e compartilhamento do poder no processo de tomada de decisão. Power to retrata o ativismo de um ator, voltado para a realização de atos que objetivam os próprios interesses, de modo a resistir a determinado modelo dominante.

Quando há dominância numa relação, o agente com mais poder exerce power over e o agente com menos poder, caso resista, exerce power to. Numa relação sem dominância entre os agentes, eles atuam exercendo power with. Mesmo num contexto no qual um ator possui muito mais poder do que os demais, é possível que ele adote a opção de exercício de power with outros Estados, no lugar de power over.

No contexto decorrente da criação do Novo Banco de Desenvolvimento, cabe uma análise dos graus de dominância do poder. Numa perspectiva interna do processo decisório do NBD, não há power over entre os membros do BRICS, pois cada país possui a mesma quantidade de votos, tanto Conselho de Governadores como no Conselho de Diretores $^{163}$. No AIIB, a China possui uma capacidade de veto, com $26,06 \%$ dos diretos de voto (a China optou pelo exercício de power over outros atores) (Cooper, 2017). O mesmo não ocorre no NBD, no qual os cinco membros possuem a mesma capacidade de voto, não havendo veto de um único ator (a China optou pelo exercício de power with outros atores).

A dominância interna existente no processo de votação é dos membros fundadores do NBD (Shelepov, 2016). Conforme o Acordo Constitutivo ${ }^{164}$, o total do número de votos dos fundadores não pode ser menor do que 55\%. Assim, fica clara uma garantia de veto aos países membros do BRICS, isto é, um power over dos membros fundadores do Banco em relação a futuros membros. No entanto, sem a adesão de novos integrantes, tal

\footnotetext{
163 BRICS. Acordo Constitutivo sobre o Novo Banco de Desenvolvimento. 2014.

164 Idem.
} 
dispositivo não produz efeitos nas votações. Ademais, pode-se identificar uma outra exceção, pois é possível ter ocorrido power over exercido pela China no momento da decisão sobre o local da sede do Banco, uma vez que a sede é em Xangai. Tal decisão foi anterior à aplicação das regras do procedimento decisório estabelecido pelo Acordo Constitutivo do Banco (a referida decisão foi analisada no tópico da dimensão peso do poder).

Como de maneira geral não há power over interno ao NBD, também não haveria power to, que por definição é uma resistência ao power over. Sem um modelo de dominância presente na estrutura institucional do Banco, logo, identifica-se um power with, isto é, um poder exercido conjuntamente entre os membros do BRICS. Considerando o aspecto geral, para qual finalidade é exercido tal poder conjunto (power with)? Nesse ponto, o entendimento passa por uma análise externa ao NBD.

Pelos dados do Índice de Desenvolvimento Humano (IDH) ${ }^{165}$, nenhum membro do BRICS possui IDH alto (acima de 8): Rússia (50 lugar com 0,798$)$, Brasil $\left(75^{\circ} \mathrm{com}\right.$ 0,755), China $\left(90^{\circ}\right.$ lugar com 0,727$)$, África do Sul $\left(116^{\circ}\right.$ com 0,666$)$ e Índia $\left(130^{\circ}\right.$ lugar com 0,606$)$. Numa narrativa segundo a qual o sistema internacional é dividido entre países desenvolvidos e países em desenvolvimento, na qual os primeiros exercem power over e os segundos resistem com power to, os integrantes do NBD exerceriam power with $\mathrm{e}$ power to visando o alcance o desenvolvimento e fim da dominação. No entanto, a referida narrativa apresenta falhas, que levam também a limitações da aplicação do conceito de power to, da maneira como ele foi concebido.

A ideia original de power to remete a uma resistência ao power over (Berger, 2005). Entretanto, a aplicação do conceito power to ao estudo das relações de poder envolvendo os NBD e seus membros fica mais viável se não houver a necessariamente ideia de resistência a uma dominação. Assim, a ideia do power to ficaria voltada principalmente a uma finalidade, sem uma oposição imediata. No caso dos membros do BRICS, uma finalidade da utilização do NBD seria o alcance do desenvolvimento, sem conflito direto com outros atores (como os países desenvolvidos).

O conceito de hegemonia interdependente (Christensen e Xing, 2016) é útil para uma compreensão da complexidade do sistema internacional que vai muito além da dicotomia países desenvolvidos vs. países em desenvolvimento. A hegemonia interdependente leva em consideração uma série de fatores interconectados, nos quais os

${ }^{165}$ Dados de 2014: http://www.br.undp.org/content/brazil/pt/home/idh0/rankings/idh-global.html Acesso: $09 / 07 / 2019$, às $19 h 51$. 
países desenvolvidos e os países em desenvolvimento estão entrelaçados num constante processo de modelagem e remodelagem da ordem internacional, havendo correlação com interesse nacional, orientação regional, formação da agenda política, alianças políticas e potenciais conflitos. A hegemonia interdependente ilustra o fato de que os países em desenvolvimento não foram capazes, até o início do século XXI, de formar um "bloco histórico" que sirva de substituto para uma hegemonia orgânica e homogênea (apesar dos esforços do G77/China). Isto acontece porque os países em desenvolvimento possuem diferentes relacionamentos com os países desenvolvidos e graus variados de influência global.

Por exemplo, conjuntamente os membros do BRICS não defendem uma reforma no número de assentos permanentes do Conselho de Segurança das Nações Unidas (CSNU), devidos às divergências entre Brasil e Índia em contraposição a Rússia e China. Por outro lado, o G4 (formado por Alemanha, Japão, Índia e Brasil) defende a reforma do Conselho de Segurança com a criação de mais assentos permanentes. Alemanha e Japão reivindicam a mudança com base nas grandes doações que realizam para as Nações Unidas. A Índia advoga a reforma com o argumento que é o segundo país mais populoso do mundo, com uma das maiores economias, e por ser o terceiro Estado que mais contribui com tropas para as missões de paz das Nações Unidas. O Brasil defende a alteração no CSNU argumentando a necessidade de representação de um país sulamericano. Índia e Brasil também se apresentam como representantes do Sul político do globo (von Freiesleben, 2008).

Trata-se de um exemplo de compartilhamento de interesses entre países em desenvolvimento (Brasil e Índia) e países desenvolvidos (Japão e Alemanha), em contraposição a outros países em desenvolvimento ${ }^{166}$ (Rússia e China). Por possuírem assento permanente no Conselho de Segurança das Nações Unidas, China e Rússia possuem uma postura mais conservadora na arquitetura global na área da segurança, no que concerne a distribuição do poder (Abdenur, 2014). Mas em outras áreas da governança global, a China advoga maior participação de países em desenvolvimento, como no FMI (demanda constante nas Declarações de Cúpula do BRICS).

Logo, o power to exercido pelos integrantes do BRICS não representa necessariamente uma oposição aos países desenvolvidos. O que o NBD fornece é um caminho diferente para o desenvolvimento. Os membros do BRICS não conseguem

\footnotetext{
${ }^{166}$ A Rússia seria um país re-emergente, na concepção de MacFarlane (2006).
} 
influenciar significativamente as instituições de Bretton Woods. Com o NBD, os integrantes do BRICS conseguem determinar o volume e a direção das assistências financeiras, em contraste com outras instituições multilaterais financeiras. Além disso, com o NBD, os membros do BRICS conseguem determinar as condições de empréstimos, o que não ocorre com o FMI nem com o Banco Mundial, os quais possuem sistemas próprios de financiamento ao desenvolvimento (Morozkina, 2015).

Quando um país toma um empréstimo do FMI, seu governo aceita ajustar a sua política econômica conforme as condicionalidades do Fundo. O conjunto de condições visa assegurar que o país tomador de empréstimo pague ao FMI, bem como resolva os problemas que levaram à solicitação de ajuda financeira. As condicionalidades incluem ações prioritárias como a eliminação de controle de preços e um orçamento com um ajuste fiscal $^{167}$.

As condições de empréstimo do FMI impactam as vidas dos indivíduos de maneira significativa (Vreeland, 2007). As condições políticas afetam gastos governamentais, logo, os programas do FMI ajudam a determinar se a construção de escolas e estradas ou o pagamento da dívida terá prioridade no orçamento do país que tomou o empréstimo. Ao abordar as taxas de juros e o valor da moeda, os programas do FMI podem afetar o próprio poder de compra da unidade monetária do país tomador de empréstimo. Infelizmente, em termos de desenvolvimento econômico, há escassas evidências de sucesso dos empréstimos condicionais do FMI.

O grau de êxito do Banco Mundial não é muito diferente (Woods, 2006). Os seus empréstimos são sujeitos a uma avaliação anual que julgam a satisfatoriedade dos programas do Banco e dos ajustes estruturais em termos de desenvolvimento do país tomador de empréstimo (como a melhoria da capacidade em utilizar os seus recursos humanos e financeiros efetivamente). Os resultados sugerem que a maioria dos projetos financiados pelo Banco tiveram resultados insatisfatórios de desenvolvimento, com baixo impacto nas instituições do país e na sustentabilidade. Pelo menos, o referido Banco possui indicadores para a avaliação de seu desempenho, o que inexistiu para o NBD até o ano de 2019, sendo um defeito do Banco do BRICS, dificultando a sua comparação com outros bancos multilaterais de desenvolvimento.

Além disso, o Banco Mundial pode determinar a realocação de valores, caso entenda ser necessário para o atendimento dos propósitos de determinado empréstimo. A

167 https://www.imf.org/en/About/Factsheets/Sheets/2016/08/02/21/28/IMF-Conditionality Acesso: $11 / 07 / 2019$, às 23 h36. 
realocação de valores inclui a modificação de categorias existentes nos projetos, a modificação do percentual a ser gasto com o financiamento do Banco em cada categoria, bem como a troca de valores entre uma categoria e outra ${ }^{168}$.

A significativa falta de investimentos em infraestrutura ao redor do mundo e a aspiração de economias emergentes, em fortalecer as suas influências nas instituições financeiras internacionais, foram fatores que levaram ao estabelecimento do Novo Banco de Desenvolvimento (Shelepov, 2016). Bancos Multilaterais de Desenvolvimento (BMD) têm potencial para contribuir com o desenvolvimento econômico e social ao redor do mundo (Andronova e Shelepov, 2018). Projetos apoiados por estas instituições frequentemente requerem grandes investimentos e recursos. Bancos multilaterais ativamente cooperam com governos nacionais, setor privado e sociedade civil em vários níveis, implementando programas com financiamento de projetos. Tal cooperação entre os BDM resultam na criação de princípios e padrões comuns, na consolidação da expertise, no compartilhamento de riscos e no aumento dos recursos financeiros disponíveis. O NBD acompanha este processo.

Os empréstimos do NBD são previstos para serem realizados de modo que os recursos sejam utilizados de maneira equilibrada entre os seus membros (power with), para o alcance do desenvolvimento (power to). Conforme o inciso IV do artigo 21 do Acordo Constitutivo $^{169}$, o Banco não fornecerá uma quantia desproporcional de seus recursos em benefício de um ou mais membros, de modo que os investimentos sejam diversificados. A praticidade de tal dispositivo depende dos atores, pois caso um membro proponha uma quantidade de projetos bem menor do que os demais, a tendência é que tal membros receba menos recursos. Por exemplo, o Brasil apresentou menos da metade da quantidade de propostas da China, até 31/05/2019 (5 brasileiras e 11 chinesas). Nesse ponto, o power with é prejudicado por baixa atividade brasileira.

O inciso VI do artigo 21 do Acordo Constitutivo ${ }^{170}$ também possui potencial para reforçar o power with entre os membros do BRICS. Segundo o referido dispositivo, os recursos dos empréstimos realizados pelo Banco serão voltados apenas para bens e serviços produzidos nos países membros da instituição, havendo exceção unicamente quando o Conselho de Diretores permitir a aquisição de bens e serviços de país não

\footnotetext{
168 https://policies.worldbank.org/sites/ppf3/PPFDocuments/225213e698394b9e8d721965fcd694e5.pdf Acesso: 12/07/2019, às 00h24.

${ }^{169}$ BRICS. Acordo Constitutivo sobre o Novo Banco de Desenvolvimento. 2014.

${ }^{170}$ Idem.
} 
membro, em circunstâncias especiais. A regra de tal dispositivo tende a estimular o comércio intra-BRICS, sendo um incentivo para as indústrias dos países membros.

O sítio oficial da Organização Mundial do Comércio (OMC) disponibiliza dados diversos sobre os fluxos comerciais internacionais, incluindo informações sobre os tipos de produtos comercializados entre países. Como a China é o membro do BRICS que mais apresentou projetos de infraestrutura, cabe uma breve análise dos volumes de exportação que Brasil, Rússia, Índia e África do Sul realizaram para o gigante asiático, considerando especificamente dois tipos de produtos utilizados em construções: produtos de ferro e aço (de menor valor agregado) e maquinários e equipamentos elétricos (de maior valor agregado).

O Banco do BRICS entrou em operação em julho de 2015. As tabelas abaixo comparam as exportações para a China de 2014 (ano anterior ao início das operações do Banco) com as exportações de 2017 (ano com os dados mais recentes disponibilizados pela $\mathrm{OMC}$ ). Os produtos de ferro e aço incluem blocos, barras, lingotes, fios, varas e outras formas primárias ${ }^{171}$. Todos os parceiros comerciais da China membros do BRICS aumentaram as suas exportações de produtos de ferro e aço: Brasil (7,5\%), Rússia (291\%), Índia (126\%) e África do Sul (21\%).

Tabela 4: Exportações de produtos de ferro e aço para a China (em USD)

\begin{tabular}{|l|r|r|}
\hline \multicolumn{1}{|c|}{ País } & 2014 & \multicolumn{1}{c|}{2017} \\
\hline Brasil & USD 618.827.992 & USD 665.631.737 \\
\hline Rússia & USD 24.919.163 & USD 97.492.691 \\
\hline Índia & USD 206.722.627 & USD 468.930.231 \\
\hline África do Sul & USD 1.314.037.453 & USD 1.601.726.960 \\
\hline
\end{tabular}

Fonte: Elaboração própria com dados extraídos de: https://data.wto.org/ Acesso: 13/07/2019, às $00 \mathrm{~h} 10$.

Os produtos de maquinários e equipamentos elétricos incluem motores, geradores, baterias, resistores, bobinas de ignição, lâmpadas, aparatos de linhas telefônicas, aquecedores, ferramentas lasers, gravadores de vídeos, entre outros ${ }^{172}$. Apenas dois parceiros da China aumentaram as suas exportações nos referidos produtos: Rússia

\footnotetext{
${ }^{171}$ Fonte: https://data.wto.org/ Acesso: 13/07/2019, às 00h10.

172 Idem.
} 
(87,6\%) e Índia (31\%). O Brasil e África do Sul tiveram reduções em tais exportações, $34,4 \%$ e $49,3 \%$, respectivamente.

Tabela 5: Exportações de produtos de maquinários e equipamentos elétricos para a China (em USD)

\begin{tabular}{|l|r|r|}
\hline \multicolumn{1}{|c|}{ País } & 2014 & 2017 \\
\hline Brasil & USD 123.162.229 & USD 80.844.054 \\
\hline Rússia & USD 42.920.231 & USD 80.511.550 \\
\hline Índia & USD 440.596.663 & USD 580.172.265 \\
\hline África do Sul & USD 12.861.915 & USD 6.515.117 \\
\hline
\end{tabular}

Fonte: Elaboração própria com dados extraídos de: https://data.wto.org/ Acesso: 13/07/2019, às $00 \mathrm{~h} 10$.

Rússia e Índia aumentaram as suas exportações para a China tanto de produtos de menor valor agregador como de produtos de maior valor agregado (entre os exemplos considerados), com destaque para os enormes saltos nos percentuais russos. Brasil e África do Sul somente aumentaram as suas exportações para a China de produtos de menor valor agregado, pois quanto aos produtos de maior valor agregado as reduções foram consideráveis.

Vários fatores influenciam o comércio internacional, como os fluxos comerciais acima elencados. Apesar disso, não deve ser descartada uma possível contribuição da normativa do Acordo do Constitutivo que incentiva o comércio intra-BRICS, por menor que seja. O NBD está nos seus primeiros anos e é uma fonte de oportunidades a ser explorada com passar do tempo, tanto para ajudar o desenvolvimento dos países (power to) como para exercício de poder conjunto (power with).

\subsection{Dimensão Grau de Transição do Poder (power shift e power remain)}

Power shift indica uma transição quanto à distribuição dos recursos de poder, não tratando especificamente dos desfechos políticos decorrentes do exercício de poder (objeto da abordagem relacional). Isto porque há uma enorme complexidade na identificação das resultantes de interesse preferenciais de cada agente, bem como na verificação do agente que têm exercitado mais poder nas inúmeras interações das relações internacionais. Não é sempre que o país com mais recursos (econômicos, militares e 
institucionais) consegue alcançar o seu interesse, como nas crises do petróleo dos anos 1970, quando os países da OPEP aumentaram o preço do produto (Keohane e Nye, 2012), apesar do poderio e das preferências contrárias do Estados Unidos.

Não se observa uma transição para todo e qualquer recurso de poder. Além disso, quando transições são observadas para alguns recursos, os graus de mudança são diferenciados. Deste modo, como explicado no capítulo teórico da presente pesquisa, sugerimos o conceito de power remain para complementação do conceito de power shift. Power remain refere-se tanto aos recursos nos quais não se verifica transição de poder, como aos recursos nos quais a transição do poder é lenta ao ponto de não se observar power shift, isto é, não se visualizar mudanças significativas em determinadas distribuições de recursos de poder. Com o título "dimensão grau de transição" para o presente tópico propomos um continuo entre dois extremos, um representado pelo conceito de power shift e o outro representado pelo conceito power remain.

A criação do Novo Banco de Desenvolvimento se enquadra no contexto da transição hegemônica, na qual a distribuição do poder mundial é alterada no sentido de uma redução relativa de recursos de poder do Estados Unidos em comparação com o restante do mundo, bem como de um aumento relativo de recursos de poder da China. A diminuição da diferença entre os PIBs das duas maiores economias do globo contribuiu para a criação de novas instituições não centradas no poder americano. O FMI e o Banco Mundial são duas das principais instituições do sistema Bretton Woods, o qual foi criado em 1944 (Frieden, 2007). O NBD e o ACR (ambos no âmbito do BRICS) foram criados em momentos que coincidem com a prolongada fase de ascensão chinesa e com as lentas mudanças nas capacidades decisórias no FMI e no Banco Mundial. Posto isso, em que medida se verifica um power shift e/ou um power remain institucional no cenário internacional?

O FMI possui 189 membros e tem como principal propósito assegurar a estabilidade do sistema monetário internacional, por meio de empréstimos para países com dificuldades na balança de pagamentos. Os recursos do FMI são provenientes de quotas atribuídas aos países membros. A atribuição das quotas deve ser baseada, de maneira geral, na posição relativa dos países na economia mundial ${ }^{173}$.

O peso do voto de cada membro do FMI (Martins, 2014) está diretamente relacionado com as quotas que cada um detém. Entretanto, o aumento do poder

${ }^{173}$ Fonte: https://www.imf.org/en/About (Acesso: 12/10/2018, às 14h54). 
econômico das potências emergentes (como China e Índia), no primeiro quartil do século XXI, não é refletido no processo decisório da organização. A lenta mudança das instituições financeiras existentes (Suchodolski e Demeulemeester, 2018) pode ser exemplificada pela demorada aprovação da $14^{\text {a }}$ Revisão Geral de Quotas do FMI. O Board of Governors do FMI, no dia 15/12/2010, concluiu a 14 a Revisão de Quotas do Fundo, com a finalidade de conferir aos países emergentes um peso de voto mais correspondente com suas participações na economia mundial. No entanto, houve a demora de cinco anos para aprovação da reforma iniciada em 2010.

Apesar da Revisão Geral efetuada pelo Board of Governors do FMI, a reforma não foi implementada até 2014 por falta de votos necessários (Martins, 2014). Para haver mudança é necessário 85\% dos votos na organização. Até abril de 2014, 159 membros acataram a reforma das quotas $(78,88 \%$ do total de votos). Como o Estados Unidos detinha $16,75 \%$ do peso dos votos, o país possuía (e possui) uma capacidade de veto, pois a aprovação do Congresso americano se faz necessária para que ocorram mudanças nas quotas do $\mathrm{FMI}^{174}$. E mesmo com a reforma de 2010, os pesos dos votos dos países continuaram não refletindo as suas participações na economia mundial.

A reforma das quotas do FMI não foi mencionada no texto da declaração da primeira cúpula presidencial do BRICS, tendo sido demonstrado apenas um interesse geral de mudança em instituições financeiras internacionais, sem especificar nenhuma organização: "Estamos comprometidos com o avanço da reforma das instituições financeiras internacionais, de forma a refletir as transformações da economia mundial. As economias emergentes e em desenvolvimento devem ter maior peso e representação nas instituições financeiras internacionais" ${ }^{175}$.

Da $2^{\mathrm{a}}$ até a $10^{\mathrm{a}}$ declaração, a reforma das quotas do FMI foi mencionada reiteradamente: "esperamos que a reforma de quotas do FMI seja concluída"176; "Preocupa-nos, contudo, o ritmo lento das reformas das quotas e da governança do FMI"177; "Conclamamos os membros do FMI a encontrar maneiras de implementar a $14^{\mathrm{a}}$ Revisão Geral de Quotas, sem maiores atrasos"178; "Continuamos profundamente

\footnotetext{
${ }^{174}$ Há itens da reforma que necessitam dos parlamentos nacionais dos países membros (Martins, 2014).

$1753^{\circ}$ parágrafo da Declaração da I Cúpula - Ecaterimburgo/Rússia (2009). Fonte: http://www.brics.utoronto.ca/ Acesso: 12/10/2018, às 14h54.

${ }^{176} 11^{\circ}$ parágrafo da Declaração da II Cúpula - Brasília/Brasil (2010). Fonte: http://www.brics.utoronto.ca/ Acesso: $12 / 10 / 2018$, às $14 h 54$.

$1779^{\circ}$ parágrafo da Declaração da IV Cúpula - Nova Delhi/Índia (2012). Fonte: http://www.brics.utoronto.ca/ Acesso: 12/10/2018, às 14h54.

$17818^{\circ}$ parágrafo da Declaração da VI Cúpula - Fortaleza/Brasil (2014). Fonte: http://www.brics.utoronto.ca/ Acesso: 12/10/2018, às 14h54.
} 
desapontados com o fracasso prolongado do Estados Unidos em ratificar o pacote de reformas do FMI de 2010"179.

A 14 Revisão Geral de Quotas do FMI trouxe as seguintes mudanças para os membros do BRICS:

Tabela 6: $14^{\text {a }}$ Revisão Geral de Quotas para os integrantes do BRICS

\begin{tabular}{|l|l|l|l|}
\hline País & $\begin{array}{l}\text { Quotas sem } \\
\text { reforma }\end{array}$ & $\begin{array}{l}\text { Quotas com a } \\
\text { reforma }\end{array}$ & Diferenças \\
\hline China & $4,00 \%$ & $6,39 \%$ & $+2,39 \%$ (aumento de $59,75 \%$ ) \\
\hline Índia & $2,44 \%$ & $2,75 \%$ & $+0,31 \%$ (aumento de $12,70 \%$ ) \\
\hline Rússia & $2,50 \%$ & $2,71 \%$ & $+0,21 \%$ (aumento de $8,4 \%$ ) \\
\hline Brasil & $1,79 \%$ & $2,32 \%$ & $+0,53 \%$ (aumento de $29,60 \%$ ) \\
\hline $\begin{array}{l}\text { África do } \\
\text { Sul }\end{array}$ & $0,78 \%$ & $0,64 \%$ & $-0,14 \%$ (redução de $17,95 \%$ ) \\
\hline
\end{tabular}

Fonte: Elaboração própria com informações extraídas de Martins (2014).

A China detém um poder econômico muito maior do que os demais membros do BRICS em conjunto. O crescimento do peso do voto da China foi maior do que a soma dos crescimentos dos outros três membros fundadores do grupo (Rússia, Índia e Brasil), de modo que o gigante asiático foi o maior beneficiado com a reforma da $14^{\text {a }}$ Revisão Geral de Quotas do FMI. Vale notar que a África do Sul assinou declarações que defenderam uma reforma que reduziu o peso de seu voto no FMI. A mudança na referida instituição financeira aumentou a assimetria de poder dentro do BRICS, ao se comparar a potência chinesa com os demais integrantes.

Com a implementação da $14^{\mathrm{a}}$ Revisão Geral de Quotas, os membros do BRICS passaram a conclamar pela $15^{\mathrm{a}}$ Revisão Geral em suas Declarações de Cúpula: "Reafirmamos o nosso compromisso de concluir a 15ª Revisão Geral das Quotas do FMI, incluindo uma nova fórmula de cota"180. Desta vez, não se reivindica apenas uma mudança de percentual das quotas, mas também a forma pela qual tal percentual é calculado. A insatisfação dos membros do BRICS com o FMI é flagrante.

$17919^{\circ}$ parágrafo da Declaração da VII Cúpula - Ufá/Rússia (2015). Fonte: http://www.brics.utoronto.ca/ Acesso: $12 / 10 / 2018$, às $14 \mathrm{~h} 54$.

$18029^{\circ}$ parágrafo da Declaração da IX Cúpula - Xiamen/China (2017) e $68^{\circ}$ parágrafo da Declaração da X Cúpula - Johanesburgo/África do Sul (trechos idênticos). Fonte: http://www.brics.utoronto.ca/ Acesso: $12 / 10 / 2018$, às $14 \mathrm{~h} 54$. 
Em 2014, durante a Cúpula de Fortaleza (Brasil) foi assinado o Tratado para o Estabelecimento do Arranjo de Contingência de Reservas (ACR). A finalidade do ACR é equivalente à do FMI (Contipelli e Picciau, 2015), isto é, o seu propósito também é voltada para prover liquidez para os países em face das dificuldades da balança de pagamentos e de futuras crises econômicas. Caso o FMI fosse satisfatório para os membros do BRICS, o ACR provavelmente não teria sido criado.

A criação de uma nova instituição envolve a aplicação de novos recursos e a utilização de novos processos decisórios (power shift). Os membros do BRICS se comprometeram a fornecer USD 100 bilhões ao ACR, com a seguinte distribuição: USD 41 bilhões da China, USD 18 bilhões do Brasil, USD 18 bilhões da Rússia, USD 18 bilhões da Índia e USD 5 bilhões da África do Sul. Além disso, o ACR possui o seu próprio processo decisório e a sua própria estrutural institucional, com o Conselho de Governadores e o Comitê Permanente. Por exemplo, cabe ao Conselho de Governadores a aprovação da adesão de novos membros ao $\mathrm{ACR}^{181}$.

No entanto, percebe-se também elementos de power remain no ACR, isto é, elementos que evidenciam a permanência do poder em instituições centradas na hegemonia do Estados Unidos. Em primeiro lugar, a unidade monetária pela qual o ACR opera é dólar americano. Em segundo lugar, no Tratado criador do ACR há 14 menções ao FMI. Por exemplo, conforme a alínea "f" do Art. 5 do Tratado, "Se uma Parte Requerente tiver um acordo em curso com o FMI, ela poderá acessar até $100 \%$ de seu limite de acesso máximo", o que significa um membro da instituição ao requerer a utilização de recursos do ACR, somente poderá atingir o seu limite de empréstimo caso já possua um acordo com o FMI. Os limites de acesso aos recursos são determinados pelos multiplicadores estabelecidos da alínea "a" do Art. 5 do Tratado vezes a participação individual de cada membro: 0,5 x USD 41 bilhões para a China, 1 x USD 18 bilhões para o Brasil, 1 x USD 18 bilhões para a Rússia, 1 x USD 18 bilhões para a Índia e 2 x USD 5 bilhões para a África do Sul.

O Tratado do ACR não apenas faz menção ao FMI (instituição do sistema Bretton Woods), mas também menciona uma instituição fora dos marcos da hegemonia americana, o NBD. Conforme o inciso IV da alínea "b" do Art. 14, para um empréstimo do ACR ser aprovado, o país não pode ter dívidas em atraso com o NBD nem com outras instituições financeiras multilaterais. Dessa forma, com o ACR proporciona laços

${ }^{181}$ BRICS. Tratado para o Estabelecimento do Arranjo Contingente de Reservas do BRICS. 2014. 
institucionais diversos, contribuindo tanto com o power shift como para o power remain. Deste modo, a China possui interesse em "acoplar" ou "embutir" ("to embed") novas instituições na ordem instaurada com o fim da Segunda Guerra Mundial (Prantl, 2014).

O Banco Mundial também passou por reformas em 2010 (Xiao, 2015). A estrutura de votação foi alterada de modo a conferir mais votos principalmente para a China, o Brasil, a Índia, a Indonésia e o Vietnã. O percentual de votos da China aumentou de 2,77\% para 4,42, passando ao terceiro lugar na capacidade decisória, ficando na frente de Reino Unido, França e Alemanha. Porém, Japão e Estados Unidos mantiveram mais votos do que a China, sendo o percentual americano de 15,85\% (Abdenur, 2014).

A demanda por reformas no Banco Mundial não foi diretamente recorrente nas Declarações de Cúpula do BRICS, no entanto, na Cúpula do BRICS de 2012, na cidade de Nova Delhi, foi iniciado um diálogo entre os membros do BRICS para análise das possibilidades de criação de um banco multilateral de desenvolvimento próprio (Shelepov, 2016). Os líderes dos cinco países concordaram com a necessidade de mobilização de recursos para infraestrutura e desenvolvimento sustentável, de modo que o novo banco poderia ser complementar às instituições financeiras internacionais. $\mathrm{Na}$ declaração de Cúpula de Nova Delhi, os membros do BRICS reivindicam uma arquitetura financeira global mais representativa, com mais voz para os países em desenvolvimento, de modo que aprimoramentos no sistema financeiro internacional contribuam para o desenvolvimento das economias dos países (Qobo e Soko, 2015).

Primeiramente, os membros do BRICS não têm intenção revisionista com relação à ordem global contemporânea, pois um de seus interesses é fazer com que as instituições globais existentes sejam mais receptivas a diferentes vozes e influências (incluindo as suas próprias) (Qobo e Soko, 2015). Em segundo lugar, a criação do Novo Banco de Desenvolvimento do BRICS é significativa, não apenas por institucionalizar o grupo (ou o agrupamento), mas também por contribuir para o reforço da arquitetura financeira global. Trata-se de uma instituição com origem diferente daquelas dos maiores bancos multilaterais de desenvolvimento (Shelepov, 2016), os quais foram criados quando a economia global era baseada na dominância do Estados Unidos. O IBRD foi estabelecido em 1944, o Inter-American Development Bank (IDB) em 1959, o Asian Development Bank (ADB) em 1963, o African Development Bank (AfDB) em 1966.

Numa comparação entre as atividades do NBD e as instituições financeiras préexistentes, há esferas de potencial duplicação e complementariedade. Índia e China são os maiores tomadores de empréstimos do Asian Development Bank, a África do Sul é o 
maior cliente do African Development Bank, a Rússia está entre os maiores tomadores de empréstimos do European Bank for Reconstruction and Development, e o Brasil está entre os maiores clientes do Inter-American Development Bank (Morozkina, 2015). Nesse sentido, o NBD pode cooperar com instituições existentes e ganhar expertise, além de apoiar a mobilização e a alocação de recursos de maneira independente.

No NBD, percebe-se elementos de power remain quanto à definição do dólar americano como a unidade monetária do Banco, conforme a alínea "a" do Art. 7 do Acordo Constitutivo, bem como quanto a memorandos de entendimento firmados entre o Banco e instituições financeiras firmadas sob o poder do Estados Unidos, como o International Bank for Reconstruction and Development ${ }^{182}$ e o Inter-American Development Bank ${ }^{183}$.

Por outro lado, no NBD também se percebe elementos de power shift. Por exemplo, a existência de um processo decisório próprio (com o Conselho de Governadores e o Conselho de Diretores), o compromisso de seus membros com a destinação recursos específicos para as suas operações (USD 100 bilhões de capital autorizado inicial) e a possibilidade da adesão de novos membros mediante a aprovação do Conselho de Governadores ${ }^{184}$. Além disso, o NBD também firmou memorandos de entendimento com instituições financeiras não centradas no poder americano, como o Asian Infrastructure Investment Bank ${ }^{185}$ e o Eurasian Development Bank ${ }^{186}$.

A compreensão acerca da transição do poder institucional e do grau power shift e de power remain fica mais evidente por meio do conceito International Institutional Bypass (Stuenkel, 2017b), cujo significado é conferir relevância às instituições préexistentes ao mesmo tempo em que se busca criar novas instituições, que ofereçam algo

\footnotetext{
${ }^{182}$ Memorandum of Understanding Between International Bank for Reconstruction and Development, International Development Association, International Finance Corporation, Multilateral Investment Guarantee Agency and New Development Bank https://www.ndb.int/wp-content/uploads/2017/01/MOU-NDB-WBG.pdf Acesso: 13/06/2019, às 22h01.

183 Memorandum of Understanding between the Inter-American Development Bank and the InterAmerican Investment Corporation and the New Development Bank on General Cooperation https://www.ndb.int/wp-content/uploads/2018/09/MOU-with-IDB-IDB-Invest-signed.pdf Acesso: $13 / 06 / 2019$, às $21 \mathrm{~h} 48$.

${ }^{184}$ BRICS. Acordo Constitutivo sobre o Novo Banco de Desenvolvimento. 2014.

${ }^{185}$ Memorandum of Understanding Between New Development Bank and Asian Infrastructure Investment Bank https://www.ndb.int/wp-content/uploads/2017/04/MOU-with-AIIBApril-2017.pdf Acesso: 20/03/2019, às $00 \mathrm{~h} 24$.

${ }^{186}$ Memorandum of Understanding Between the New Development Bank and the Eurasian Development Bank on General Cooperation https://www.ndb.int/wp-content/uploads/2017/04/MOU-with-EDBApril2017.pdf Acesso: 13/06/2019, às 21h50.
} 
diferente do já oferecido pelas instituições pré-existentes. Deste modo, a criação de novas instituições não é um ato revolucionário. Trata-se de um multilateralismo competitivo. Novas instituições financeiras como o AIIB e o NBD se baseiam no conhecimento e as experiências de instituições já existentes. Muito das estruturas institucionais criadas pela China e pelo BRICS são complementares às estruturas existentes.

Um multilateralismo excessivamente competitivo pode erodir normas universais caso o International Institutional Bypass alcance padrões globais (Stuenkel, 2017b). No entanto, a falta de competição mina a efetividade e a agilidade de qualquer instituição, pois a competição colabora para a geração de novas ideias e o desenvolvimento de melhores práticas.

O conceito de International Institutional Bypass (Stuenkel, 2017b) ajuda a explicar os empreendimentos chineses de uma forma mais sofisticada, evitando a abordagem simplista que visualiza ou "integração" ou "ruptura" nas novas instituições internacionais. Tal power shift requer das grandes potências barganha constante e renegociação dos acordos com o restante do mundo. Logo, as criações e o funcionamento do AIIB e do NBD evidenciam uma transição, mas sem ruptura. 


\section{CONCLUSÃO}

O Novo Banco de Desenvolvimento foi analisado tendo por base o marco teórico do conceito de poder. Conforme a revisão de literatura do capítulo teórico, na perspectiva do poder como recurso, ele é possuído. Na perspectiva relacional, o poder é exercido e produz efeitos. Por tal ótica, a análise ganha detalhamento quando se especifica, não apenas quem detêm o poder, mas também quais são os agentes relacionados e os temas envolvidos.

A ótica relacional possibilita a percepção do poder em dimensões, sem eliminar o entendimento da perspectiva do poder como recurso. As dimensões escopo, domínio, peso, custos e meios foram identificadas por Baldwin (2013). A diferença entre recursos e meios reside apenas no momento da análise. Enquanto o termo "recurso" é empregado e verificado antes de uma dada relação de poder ocorrer, o meio de exercício do poder é empregado e verificado após as ações dos atores (análise posterior à determinada relação entre agentes).

Com uma combinação das abordagens de vários autores, identificamos 11 dimensões do poder: escopo, domínio, custos, peso, meios, método de aplicação de meios, geográfica, incidência, agência vs. estrutura, grau de transição e grau de dominância. $O$ NBD foi analisado com base nas categorias acima listadas, de modo a ser testada a hipótese de que normas e atos institucionais do Banco do BRICS constituem um meio de exercício de poder, com fungibilidade (isto é, trata-se de um meio com repercussão em outras dimensões do poder). Dados empíricos foram coletados e analisados para verificação da hipótese, a qual se confirma (levando em consideração algumas observações).

Há ressalvas, pois não foram afastadas toda e qualquer hipótese alternativa. A única hipótese rival afastada é a de que o Banco do BRICS seria uma instituição fundamentalmente técnica, sem repercussões políticas. Não foi negada a possibilidade de um agente ser imparcial. A argumentação, que afastou a ideia da existência de uma predominância da imparcialidade no NBD, foi voltada ao questionamento da frequência com a qual o Banco é marcado pela característica da imparcialidade. Em diversos aspectos o Banco do BRICS traz implicações às relações de poder, como explicada ao longo da pesquisa (dimensão meio de exercício de poder).

O escopo refere-se aos temas envolvidos numa determinada relação de poder. Conforme teorizou Wendt (1999), o poder é constituído por interesses, os quais são 
constituídos por ideias. Diante da comunidade internacional, o Banco do BRICS reforça uma ideia de desenvolvimento voltada para a sustentabilidade e para a infraestrutura. Tal perspectiva acerca do conceito de desenvolvimento é útil para atrair novos agentes e aumentar a quantidade de atores participantes das ações do Banco.

O domínio indica a quantidade de atores participantes de uma dada relação de poder. O Banco do BRICS aumenta as suas interações com outras instituições financeiras multilaterais, por meio da assinatura de atos diplomáticos (como memorandos de entendimento). De maneira geral, os referidos documentos preveem a possibilidade de financiamento conjunto em países de interesse comum, por parte das instituições signatárias. As possibilidades de atuação do NBD ficam ampliadas, pois possuem dezenas de membros os bancos multilaterais de desenvolvimento que firmaram atos diplomáticos com o Banco do BRICS.

Há uma ênfase na aproximação com instituições financeiras multilaterais, em que os membros do BRICS possuem uma posição de relevância, possibilitando a ampliação do âmbito das operações do NBD. Verificam-se aplicações práticas do conceito de BRICS+Circle, com o estabelecimento de múltiplos acordos que aumentam a capilaridade do BRICS em diversas regiões do globo, sem o engessamento das ações devido à flexibilidade do modelo de relacionamento institucional. É certo que os Estados são soberanos e as normas multilaterais não são necessariamente cumpridas, no entanto, com o cumprimento de parte dos acordos firmados entre NBD e outras instituições financeiras, já haverá um saldo positivo para o BRICS, no sentido do aumento do número de atores envolvidos em suas políticas financeiras.

Com exceção do AIIB, as demais instituições com as quais o NBD firmou memorandos de entendimento já existiam antes de sua criação, de modo que elas já estavam em pleno funcionamento sem precisar do Banco do BRICS. É o NBD que tem mais a ganhar com tais atos diplomáticos estabelecidos. Há um aprendizado institucional mútuo, no entanto, uma instituição criada há poucos anos tende a usufruir mais do relacionamento com outras instituições que operam por décadas, do que o contrário. Instituições financeiras pré-existentes já possuem experiência bem como já divulgaram os seus feitos para diversos países. Novas instituições aprendem com experiências anteriores e divulgam as suas propostas institucionais para membros de outras instituições, na expectativa de novas adesões.

O exercício de poder, como o que ocorre no âmbito do NBD, não é gratuito. A dimensão custos capta tal aspecto presente nas relações políticas. Há viabilidade na 
mensuração de custos econômicos, embora não sejam os únicos (conforme o instrumental analítico, podem-se identificar custos sociais e políticos, entre outros). A forma utilizada, para mensurar os custos econômicos da manutenção e do funcionamento do NBD para os seus membros, foi realizada com a análise do percentual do PIB dos países utilizados para a composição do capital social do Banco.

A China é o país com menor custo relativo (pois o custo absoluto será o mesmo para todos os membros, uma vez que cada país se comprometeu em fornecer a mesma quantidade de recursos para o capital social do NBD, conforme o Acordo Constitutivo). No extremo oposto está a África do Sul, país de menor PIB e que por consequência tem o maior custo relativo em relação às suas obrigações com o Banco do BRICS. Brasil, Rússia e Índia ocupam colocações intermediárias. Nos três primeiros anos de funcionamento do NBD, a Rússia foi o país mais adiantado no fornecimento dos recursos obrigatórios ao Banco.

Mesmo considerando a premissa de que a criação e a manutenção do Banco do BRICS são de interesse de todos os seus países integrantes (num mesmo grau de prioridade), a China é o agente que exerceu mais poder nestas relações institucionais. Os custos absolutos são os mesmos (do capital social), mas devido ao fato de a economia chinesa ser maior do que a soma das economias dos demais membros do BRICS, os custos relativos da China são muito menores. O ônus de um capital social igualmente distribuído é vantajoso para a China, e desvantajoso para os demais integrantes do NBD.

Outro ponto no qual a China obteve vantagem foi na distribuição dos elementos institucionais de destaque do Banco do BRICS (como as presidências do Banco, do Conselho de Governadores, do Conselho de Diretores, a sede da Banco e a localização do primeiro escritório regional). A China ficou com a sede (que é única e não rotativa). Os demais membros do BRICS ficaram ou com um primeiro exercício das presidências (as quais são rotativas), ou com o primeiro dos escritórios regionais (que não são únicos). Numa comparação com outros bancos multilaterais de desenvolvimento, verificou-se que não é comum o país de maior PIB ficar com a sede. Logo, depreende-se que a China exerceu um peso maior na decisão de escolha da sede (dimensão peso do poder).

No entanto, a vantagem da China não confere ao país um poder estrutural (dimensão agência vs. estrutura). A estrutura institucional do Banco do BRICS é predominantemente equitativa, quando a capacidade de voto se seus membros fundadores. Os agentes possuem margens de manobra equivalentes, de modo que o poder prevalecente é o dos agentes, não sendo perceptível um poder estrutural por parte de 
nenhum membro em detrimento dos demais. Apenas com a adesão de futuros países ao NBD, será visível um poder estrutural dos membros fundadores em relação aos novos membros, no que concerne a capacidade de voto, uma vez que alguns dispositivos do Acordo Constitutivo fazem menção a necessidade de votos de membros fundadores para a aprovação de determinadas decisões.

O poder dos agentes ser equivalente não significa que todos os membros do Banco atuam na instituição numa mesma intensidade. Justamente, por prevalecer o poder dos agentes, é visível a diferença de engajamento dos atores na instituição em tela. China e Índia demonstram mais interesse em apresentar projetos de infraestrutura para serem financiados com recursos do NBD. Rússia e Índia ocupam uma posição intermediária. O Brasil é o país com a menor participação no tocante à quantidade de projetos apresentados, o que pode ser interpretado como uma baixa utilização do poder de agência por parte dos brasileiros, além de um desperdício de oportunidades fornecidas pelo NBD.

Os projetos de infraestrutura financiados pelo Banco do BRICS repercutem nos aspectos geográficos dos países membros, contribuindo para os seus poderes terrestre, marítimo e aéreo (dimensão geográfica do poder). Até o momento, nenhum membro do NBD propôs um projeto concernente ao poder espacial, como satélites e plataformas de lançamento de foguetes. Apesar de o poder cibernético tratar de um ambiente virtual e computacional, a sua existência depende de infraestruturas físicas. Brasil e Rússia foram os únicos países que apresentaram projetos que contribuem para os seus respectivos poderes cibernéticos. A proposta brasileira é restrita à região Norte do país, que receberá cabos de fibra óptica. A proposta russa é de âmbito nacional, com sistemas eletrônicos para o judiciário do país.

Somente projetos chineses atribuíram atenção ao poder aéreo, com a criação de um aeroporto. O poder terrestre é contemplado por projetos de todos os membros do BRICS. A Índia conferiu maior importância ao poder terrestre em suas proposições, as quais visam a construção diversas rodovias e pontes. O poder marítimo recebeu maior atenção da China, com várias propostas que visam um maior emprego de recursos hídricos do país, incluindo a construção de parques eólicos offshore. A África do Sul foi o único integrante do NBD que propôs um projeto com obras em território de um país externo ao BRICS. Trata-se da proposta para deslocamento de água do Lesoto para um rio sul-africano.

No entanto, tais obras de infraestrutura não se manifestam de maneira imediata, isto é, os efeitos das construções terão impactos de médio a longo prazo, de modo que se 
verifica uma incidência indireta do poder proporcionado pelo Banco (dimensão incidência do poder). Um maior tempo, para se observar as consequências de ações políticas, não significa uma menor relevância dos efeitos indiretos em comparação com aqueles de impactos imediatos. O atingimento de objetivos passa por planejamentos estratégicos, táticos e operacionais (Chiavenato, 2014). Políticas de Estado não focam somente em resultados diretos, pois grandes transformações num determinado país requerem estratégias com um percurso temporal muitos anos, ou até algumas décadas.

Com o decorrer dos anos é possível também que o comércio intra-BRICS aumente em decorrência, em parte, do dispositivo do Acordo Constitutivo que incentiva a utilização de recursos dos financiamentos dos projetos, para aquisição de bens e serviços produzidos em países membros do NBD. Há uma oportunidade para o power with, isto é, um poder exercido conjuntamente, no caso, em relações comerciais. Entretanto, caso alguns países concentrem as suas exportações em produtos primários e importações em produtos manufaturados, há uma tendência para o reforço de uma balança comercial desfavorável, marcada pela dependência. Nesta situação, o país importador de produtos primários e exportador de manufaturas tenderá a exercer power over (dimensão grau de dominância).

Nos primeiros anos de funcionamento do Banco, as exportações russas e indianas para a China aumentaram, tanto de produtos de maior como de menor valor agregado. Por outro lado, as exportações brasileiras e sul-africanas para a China somente aumentaram em relação aos produtos de menor valor agregado, uma vez que as exportações de produtos de maior valor agregado diminuiram significativamente. Brasil e África do Sul não têm aproveitado as oportunidades comerciais proporcionadas pelo Acordo Constitutivo do NBD, no que tange à venda de produtos e serviços necessários para a realização dos projetos de infraestrutura propostos pela China e financiados pelo Banco.

Além dos impactos intra-BRICS, o NBD também possui potencial para repercutir no contexto da transição hegemônica (Estados Unidos - China), tanto para o power remain como para o power shift (dimensão grau de transição do poder). O Banco do BRICS contribui com power remain ao utilizar o dólar americano como moeda para os empréstimos, bem como ao firmar memorandos de entendimento com instituições centradas no poder dos Estados Unidos. Os dois exemplos citados são de power remain por não contribuírem diretamente para a transição hegemônica. Quando o NBD utilizar 
predominantemente outras moedas de referência, como o renminbi, o Banco terá mais um elemento de power shift.

Considerando outros aspectos, o NBD colabora também para o power shift. O Banco do BRICS possui uma estrutura institucional, com processo decisório específico, além de recursos na ordem de bilhões de dólares para financiamento de projetos. Ademais, a instituição é aberta a novos membros e firmou memorandos de entendimento com instituições não patrocinadas pelo poder americanos. O NBD não se enquadra totalmente nas ideias de "ruptura" ou "integração", evidencia-se um caso de multilateralismo competitivo (Stuenkel, 2017b), por se tratar de uma instituição que se apresenta como alternativa sem excluir medidas de aproximação com instituições préexistentes.

A atração do soft power e a estratégia do smart power (Nye, 2013) estão presentes no NBD (dimensão método de aplicação de meios). Num cenário internacional no qual a maioria dos países não são desenvolvidos, mostra-se estratégica e atrativa a criação de um Banco que se propõe a auxiliar países a alcançarem o desenvolvimento. Ademais, o NBD é observador na Assembleia Geral das Nações Unidas.

Depreende-se dos dados empíricos analisados que o Banco do BRICS foi instituído, entre outros possíveis motivos, para ser um meio de exercício de poder para os seus membros, muito mais do que uma simples alternativa para o financiamento do desenvolvimento sustentável. O Estados Unidos também atua com liderança ${ }^{187}$ em vários bancos multilaterais de desenvolvimento, reforçando o argumento de que tais instituições podem ser utilizadas como meio de exercício de poder. Há participação norte-americana nos bancos: International Bank for Reconstruction and Development, Inter-American Development Bank, European Bank for Reconstruction and Development, African Development Bank e Asian Development Bank.

Sugerimos para futuras pesquisas o aprofundamento do estudo em dimensões do poder para análise em separado, como a dimensão geográfico, por exemplo. A literatura da geopolítica tem muito a contribuir para o debate acerca de instituições que financiam projetos de infraestrutura, notadamente no que concerne à segurança energética. Outros conceitos também podem ser considerados na investigação sobre o Banco do BRICS, como cooperação, status e coalizões.

187 Fonte: https://home.treasury.gov/policy-issues/international/multilateral-development-banks Acesso: $28 / 10 / 2019$, às $10 \mathrm{~h} 44$. 


\section{REFERÊNCIAS}

ABDENUR. Adriana. China and the BRICS Development Bank: Legitimacy and Multilateralism in South-South Cooperation. IDS Bulletin, Volume 45, Number 4, 2014.

ALMEIDA, Paulo Roberto. O Bric e a substituição de hegemonias: um exercício analítico (perspectiva histórico-diplomática sobre a emergência de um novo cenário global). In: BAUMANN, Renato (org.) O Brasil e os demais BRICs: Comércio e Política. CEPAL/IPEA, 2010.

ALTER, Karen. J.; RAUSTIALA, Kal. 2018. The Rise of International Regime Complexity Annual Review of Law and Social Science 14: 329-49.

ANDRONOVA, I.; SHELEPOV, A. (2018) Engagement between the New Development Bank and Other Development Banks: A Formal Basis for Future Cooperation. International Organisations Research Journal, vol. 13, no 1, pp. 99-113.

ARISTÓTELES. Politics. Cambridge: Hackett Publishing, 1998.

BÄCHTOLD, Ciro. Contabilidade Básica. Curitiba: Instituto Federal do Paraná, 2011.

BALDWIN, David. Power and International Relations. In: CARLSNAES, Walter; RISSE, Thomas; SIMMONS, Beth. Handbook of International Relations. SAGE Publications Ltd, 2013 (pp. 273-292).

BARNETT, Michael; DUVALL, Raymond (2005). Power in International Politics. International Organization, 59, pp 39-75.

BECARD, Danielly; CASTRO, Aline (2013). As Relações China-ASEAN e a construção da liderança sub-regional chinesa: economia e diplomacia (1997-2010). Carta Internacional. Vol. 8, n. 1, jan.-jun. 2013 [p. 22 a 47].

BERGER, Bruce. (2005): Power Over, Power With, and Power to Relations: Critical Reflections on Public Relations, the Dominant Coalition, and Activism, Journal of Public Relations Research, 17:1, 5-28.

BLANCHARD, Jean-Marc F.; FLINT, Colin (2017) The Geopolitics of China's Maritime Silk Road Initiative, Geopolitics, 22:2, 223-245.

BOBBIO, Norberto; MATTEUCI, Nicola; PASQUINO, Gianfranco. Dicionário de Política. Brasília: UnB, 2004. Verbete: Política.

BOND, Patrick. BRICS banking and the debate over sub-imperialism. Third World Quarterly. Volume 37, 2016 - No 4.

CALIXTRE, André; BARROS, Pedro. O Banco do Sul e o Brasil na agenda da nova arquitetura financeira regional. Boletim de Economia e Política Internacional. IPEA, $\mathrm{N}^{\mathrm{o}}$ 3, julho, 2010. 
CHIAVENATO, Idalberto. Introdução à Teoria Geral da Administração. Barueri: Editora Manole, 2014.

CHRISTENSEN, Steen Fryba; XING, Li. Emerging Powers, Emerging Markets, Emerging Societies: Global Responses. Palgrave Macmillan (UK), 2016.

CONTIPELLI E.P., PICCIAU. S. BRICS Members' Interests and Priorities for Cooperation. - The Institutional Status of the BRICS and Pragmatic Cooperation: The Case of South America. International Organisations Research Journal. Vol. 10. No 2 (2015).

DAHL, Robert. The Concept of Power. Behavioral Science, 2:3 (1957:July).

DE MEUR, Gisèle; BURSENS, Peter; GOTTCHEINER, Alain. MSDO/MDSO Revisited por Public Policy Analysis. In: RIHOUX, Benoît; GRIMM, Heike. Innovative Comparative Methods for Policy Analysis - Beyond the Quantitative-Qualitative Divide. New York: Springer, 2006.

DI PIETRO, Maria Sylvia Zanella. Direito Administrativo. São Paulo: Atlas, 2014 (27 Ed.).

FERDINAND, Peter. Rising powers at the UN: an analysis of the voting behaviour of BRICS in the General Assembly. Third World Quarterly (2014), 35:3, 376-391.

FRIEDEN, Jeffry. Global Capitalism: Its Fall and Rise in the Twentieth Century. New York: W. W. Norton \& Company, 2007.

HALL, Peter, A.; TAYLOR, Rosemary, C. R. (2003) As Três Versões do NeoInstitucionalismo. Lua Nova, ${ }^{0}$ 58: p. 193-223.

HOOIJMAAIJERS, Bas; KEUKELEIRE, Stephan. Voting Cohesion of the BRICS Countries in the UN General Assembly, 2006-2014. Global Governance 22 (2016), 389407.

IKENBERRY, John. After Victory: Institutions, Strategic Restraint, and the Rebuilding of Order After Major Wars. New Jersey: Princeton University Press, 2001.

KELLY, Phil. Classical Geopolitics: A New Analytical Model. Stanford University Press, 2016.

KEOHANE, Robert; NYE, Joseph. Power and Interdependence. 4. ed. New York: Longman, 2012.

KRASNER, Stephen D. Structural Causes and Regime Consequences: Regimes as Intervening Variables. International Organization, Vol. 36, No. 2, International Regimes, (Spring, 1982), pp. 185-205.

LISSOVOLIK, Yaroslav. BRICS-PLUS: Alternative Globalization in the Making? \#69 Valdai Papers. Julho de 2017. 
LIU, M. (2016). BRICS development: a long way to a powerful economic club and new international organization. The Pacific Review, 29(3), 443-453.

MACFARLANE, Neil (2006). The ' $R$ ' in BRICs: is Russia an emerging power? International Affairs 82, I ,41-57.

MACKINDER, Halford. The Geographical Pivot of History (1904). In: TUATHAIL, Gearóid; DALBY, Simon; ROUTLEDGE, Paul. The Geopolitics Reader. London: Routledge, 1998.

MARTINS, Aline. Moeda, Estado e Poder: Limites dos Direitos Especiais de Saque Enquanto Alternativa ao Dólar como Moeda-Chave. Tese de Doutourado apresentada ao Instituto de Filosófia e Ciências Humanas da Unicamp, para obtenção do título de Doutora em Ciência Política. 2014.

MONTENEGRO, Renan Holanda; MESQUITA, Rafael. Leaders or Loners? How Do the BRICS Countries and their Regions Vote in the UN General Assembly. Brazilian Political Science Review, 2017.

MORAES, Alexandre de. Direito Constitucional. São Paulo: Atlas, 2003 (13ª Ed.).

MOROZKINA, Alexandra. The New Development Bank in the Global Financial Architecture. International Organisations Research Journal. Vol. 10. No 2 (2015).

NAIK, Shraddha. Rising BRICS: A Path to Multipolar World Reality? Сравнительная политика. 2018 T.9 N ${ }^{\circ} 1$.

NYE, Joseph. Public Diplomacy and Soft Power. ANNALS, AAPSS, 616, March 2008.

NYE, Joseph. The Future of Power. Nova York: Public Affairs, 2011.

POPPER, Karl. A Lógica da Pesquisa Científica. São Paulo: Editora Cultrix, 2007.

PRANTL, Jochen. 2014. Taming Hegemony: Informal Institutions and the Challenge to Western Liberal Order. The Chinese Journal of International Politics. Vol. 0, No. 0.

QOBO, Mzukisi; SOKO, Mills (2015) The rise of emerging powers in the global development finance architecture: The case of the BRICS and the New Development Bank, South African Journal of International Affairs, 22:3, 277-288.

RIHOUX, Benoît. Diseños de investigación em QCA. In: MEDINA, Iván; ORTIZ, Pablo; ÁLAMOS-CONCHA, Priscilla; RIHOUX, Benoît; Análisis Cualitativo Comparado (QCA) - Cuadernos Metodológicos 56. Madrid: Centro de Investigaciones Sociológicas, 2017.

ROMEIRO, Ademar. Desenvolvimento sustentável: uma perspectiva econômicoecológica. Estudos avançados 26 (74), 2012.

ROSENAU, James. Governança sem Governo: Ordem e Transformação na Política Mundial. Editora: Imprensa Oficial. 2000. 
SHELEPOV. Andrey. Comparative Prospects of the New Development Bank and Asian Infrastructure Investment Bank. International Organisations Research Journal. Vol. 11. No 3 (2016).

STRANGE, S. The Study of International Political Economy. In: States and Markets. $2^{\mathrm{a}}$.Ed. London: Pinter Publishers, 1994 [1988], p. 7-42.

STUENKEL, Oliver. Emerging powers and status: the case of the first Brics summit. Asian Perspective - Vol. 38 Núm. 1, Janeiro 2014.

STUENKEL, Oliver. Post-Western World: How emerging powers are remaking Global Order. Polity Press, 2016.

STUENKEL, Oliver. BRICS e o Futuro da Ordem Global. São Paulo: Paz e Terra, 2017.

STUENKEL, Oliver. New Development Banks as Horizontal International Bypasses: Towards a Parallel Order? Symposium on International Institutional Bypass. AJIL UNBOUND, Vol. 111, $2017 \mathrm{~b}$.

SUCHODOLSKI, Sergio; DEMEULEMEESTER, Julien. The BRICS Coming of Age and the New Development Bank. Global Policy (2018).

URIO, Paolo. China 1949-2019: From Poverty to World Power. Springer Nature: Singapore Pte Ltd. 2019

US Army. As Grandes Decisões Estratégicas (II Guerra Mundial). Rio de Janeiro: Biblioteca do Exército, 1977.

VON FREIESLEBEN, Jonas. Managing change at the United Nations. 2008. Disponível em: $\quad<$ http://www.centerforunreform.org/sites/default/files/Jonas.pdf $>$. Acesso: $12 / 10 / 2018$, às $13 \mathrm{~h} 17$.

VREELAND. James Raymond. The International Monetary Fund Politics of conditional lending. Routledge: London, 2007.

WEBER, Max. The Theory of Social and Economic Organization. New York: Oxford University Press, 1947.

WENDT, A. The Agent-Structure Problem in International Relations Theory. In International Organization, Vol. 41, No. 3 (Summer, 1987), pp. 335-370.

WENDT, Alexander. Social Theory of International Politics. Cambridge: Cambridge University Press, 1999.

WEF (2013) Strategic Infrastructure: Steps to Prepare and Accelerate Public-Private Partnerships. May 2013. Geneva: World Economic Forum.

WIGHT, Martin. A Política do Poder. São Paulo: Ed. UnB, 2002. 
WOODS, Ngaire. Globalizers: The IMF, the World Bank, and Their Borrowers. Cornell University Press: London, 2006.

YEH, Emily. Introduction: The geoeconomics and geopolitics of Chinese development and investment in Asia. Eurasian Geography and Economics, 2016, Vol. 57, No 3, pp. 275-285.

YOUNG, Iris. O ideal da imparcialidade e o público cívico. Revista Brasileira de Ciência Política, nº 9. Brasília, setembro - dezembro de 2012, pp. 169-204.

XIAO, Ren (2015). A reform-minded status quo power? China, the G20, and reform of the international financial system, Third World Quarterly, 36:11, 2023-2043.

ZHANG, Wenxian; ALON, Ilan; LATTEMANN, Christoph. China's Belt and Road Initiative: Changing the Rules of Globalization. Palgrave Macmillan, 2018.

Sítios:

Asian Development Bank (ADB)

https://www.adb.org/ Acesso: 17/06/2019, às 21 h09.

African Development Bank (AfDB)

https://www.afdb.org/en Acesso: 15/08/2019, às $20 \mathrm{~h} 09$.

Arab Bank for Economic Development in Africa (BADEA)

https://www.badea.org/ Acesso: 15/08/2019, às $20 \mathrm{~h} 10$.

Asian Infrastructure Investment Bank (AIIB)

https://www.aiib.org/en/index.html Acesso: 16/06/2019, às 19h36.

Banco Mundial (BM) - Área dos Países

https://data.worldbank.org/indicator/AG.LND.TOTL.K2?view=chart

Acesso: 30/06/2019, às 11h34.

Banco Mundial (BM) - Condicionalidades

https://policies.worldbank.org/sites/ppf3/PPFDocuments/225213e698394b9e8d721965f cd694e5.pdf Acesso: 12/07/2019, às 00h24.

Banco Nacional de Desenvolvimento Econômico e Social (BNDES) https:/www.bndes.gov.br/wps/portal/site/home/quem-somos Acesso: 02/06/2019, às $20 \mathrm{~h} 40$.

Belt and Road Initiative (BRI)

https://eng.yidaiyilu.gov.cn/qwyw/rdxw/1046.htm Acesso: 19/03/2019, às 10h31.

Black Sea Trade and Development Bank (BSTDB)

https://www.bstdb.org/ Acesso: 15/08/2019, às $20 \mathrm{~h} 12$. 
BRICS Information Center

http://www.brics.utoronto.ca/ Acesso: 12/10/2018, às 14h54.

Caribbean Development Bank (CDB)

https://www.caribank.org/ Acesso: 15/08/2019, às 20h12.

Central African States Development Bank (BDEAC)

https://www.bdeac.org/ Acesso: 15/08/2019, às 20h13.

Central American Bank for Economic Integration (CABEI)

https://www.bcie.org/en/ Acesso: 15/08/2019, às 20h13.

Central Intelligence Agency (CIA)

https:/www.cia.gov/library/publications/the-world-factbook/fields/282.html

Acesso: 30/06/2019, às 11h35.

Corporación Andina de Fomento

https://www.caf.com/pt/ Acesso: 15/06/2019, às $15 \mathrm{~h} 41$.

Council of Europe Development Bank (CEB)

https://coebank.org/en/ Acesso: 15/08/2019, às 20h14.

Deutsche Welle (DW)

https://www.dw.com/pt-br/hist $\% \mathrm{C} 3 \% \mathrm{~B} 3$ rico-da-rela $\% \mathrm{C} 3 \% \mathrm{~A} 7 \% \mathrm{C} 3 \% \mathrm{~A} 30$-entre$\% \mathrm{C} 3 \% \mathrm{ADndia}-\mathrm{e}-$ paquist $\% \mathrm{C} 3 \% \mathrm{~A} 3 \mathrm{o} / \mathrm{a}-47717117$

Acesso: 06/07/2019, às 11h39.

Development Bank of Latin America (CAF)

https://www.caf.com/en/ Acesso: 15/08/2019, às 20h14.

Diplomat (The)

https:/thediplomat.com/2019/05/china-india-border-talks-remain-stalled-amid-mapburning-controversy/ Acesso: 17/10/2019, às 17h34.

East-African Development Bank (EADB)

http://eadb.org/ Acesso: 15/08/2019, às 20h15.

Economic Cooperation Organization Trade and Development Bank (ETDB) http://www.etdb.org/ Acesso: 15/08/2019, às 20h16.

Eskom Holdings SOC Ltd:

http://www.eskom.co.za/Pages/Landing.aspx Acesso: 04/06/2019, às 17h36.

Eurasian Development Bank (EDB)

https://eabr.org/en/ Acesso: 15/08/2019, às 20h16.

European Bank for Reconstruction and Development (EBRD)

https://www.ebrd.com/home Acesso: 15/08/2019, às 20h17. 
European Investment Bank (EIB)

https://www.eib.org/en/index.htm Acesso: 15/08/2019, às 20h17.

Fondo Financiero para el Desarrollo de la Cuenca del Plata (FONPLATA)

https://www.fonplata.org/ Acesso: 15/08/2019, às 20h18.

Forças Espaciais dos Estados Unidos

https:/www.defensenews.com/smr/defense-news-conference/2018/09/05/the-top-airforce-official-is-now-onboard-with-trumps-space-force-plan/ Acesso: 01/05/2019, às $19 \mathrm{~h} 41$.

Foreign Affairs

https:/www.foreignaffairs.com/articles/china/1967-07-01/tension-sino-soviet-border

Acesso: 17/10/2019, às $17 \mathrm{~h} 32$.

Fundo Monetário Internacional (FMI) - PIB

https://www.imf.org/external/datamapper/NGDP_RPCH@WEO/OEMDC/ADVEC/WEOWOR

LD Acesso: 02/05/2019, às 9h11.

Fundo Monetário Internacional (FMI) - Condicionalidades

https://www.imf.org/en/About/Factsheets/Sheets/2016/08/02/21/28/IMF-Conditionality Acesso: 11/07/2019, às 23h36.

Industrial Development Corporation of South Africa Limited (IDC)

https://www.idc.co.za/ Acesso: 04/06/2019, às 17h40.

Instituto Brasileiro de Geografia e Estatística (IBGE)

https://biblioteca.ibge.gov.br/visualizacao/livros/liv95013.pdf Acesso: 02/06/2019, às $20 \mathrm{~h} 39$.

Inter-American Development Bank (IADB)

https://www.iadb.org/pt Acesso: 15/08/2019, às 20h18.

Inter-American Investment Corporation

https://www.iic.org/en Acesso: 15/06/2019, às 16h21.

International Bank for Reconstruction and Development (IBRD)

https://www.worldbank.org/en/who-we-are/ibrd Acesso: 15/08/2019, às 20h19.

International Development Association

http://ida.worldbank.org/ Acesso: 17/06/2019, às 20h25.

International Finance Corporation

https://www.ifc.org/wps/wcm/connect/corp ext content/ifc external corporate site/ho me Acesso: 17/06/2019, às 20h33.

International Investment Bank (IIB)

https://iib.int/en Acesso: 15/08/2019, às 20h20. 
Islamic Development Bank (IsDB)

https://www.isdb.org/ Acesso: 15/08/2019, às 20h20.

Mercado Comum do Sul (Mercosul)

https://www.mercosur.int/pt-br/decisao-sobre-a-suspensao-da-republica-bolivariana-davenezuela-no-mercosul/ Acesso: 05/08/2019, às 22h41.

Ministry of External Affairs da Índia (Canal Oficial no YouTube): https://www.youtube.com/watch?v=C0QFkzZ_zwg Acesso: 01/08/2019, às 10h49.

Ministry of External Affairs da Índia (Sítio Oficial): https://mea.gov.in/bilateraldocuments.htm?dtl/30442/Media Statement on Meeting of BRICS Ministers of For eign Affairs International Relations Acesso: 01/08/2019, às $11 \mathrm{~h} 01$.

Multilateral Investment Guarantee Agency

https://www.miga.org/ Acesso: 17/06/2019, às $20 \mathrm{~h} 38$.

Nordic Investment Bank (NIB)

https://www.nib.int/ Acesso: 15/08/2019, às 20h21.

Novo Banco de Desenvolvimento (NBD)

https://www.ndb.int/ Acesso: 31/05/2019, ás $21 \mathrm{~h} 01$.

Organização Mundial do Comércio (OMC)

https://data.wto.org/ Acesso: 13/07/2019, às 00h10.

Petróleo Brasileiro SA (Petrobrás)

http://transparencia.petrobras.com.br/sites/default/files/Estatuto-Social-AGOE-27-

Abril-2017-Portugues.pdf Acesso: 02/06/2019, às 20h44.

Programa das Nações Unidas para o Desenvolvimento (PNUD) - IDH

http://www.br.undp.org/content/brazil/pt/home/idh0/rankings/idh-global.html

Acesso: 29/07/2019, às $11 \mathrm{~h} 29$.

Public Joint Stock Company (SIBUR Holding)

https://www.sibur.ru/en/about/overview/ Acesso: 04/06/2019, às 17h28.

Sanções econômicas à Venezuela

https://www.dw.com/pt-br/eua-aplicam-novas-san $\% \mathrm{C} 3 \% \mathrm{~A} 7 \% \mathrm{C} 3 \% \mathrm{~B} 5 \mathrm{es}-\% \mathrm{C} 3 \% \mathrm{~A} 0$ -

venezuela/a-40246608 Acesso: 02/05/2019, às, 10h52.

Stockholm International Peace Research Institute (SIPRI)

https://www.sipri.org/sites/default/files/Data\%20for\%20all\%20countries $\% 20$ from $\% 201988 \% \mathrm{E}$ 2\%80\%932018\%20in $\% 20$ constant $\% 20 \% 282017 \% 29 \% 20$ USD $\% 20 \% 28$ pdf $\% 29$.pdf Acesso: 02/05/2019, às 9 h13.

Taxação de produtos entre Estados Unidos e China

https://www.bbc.com/news/business-45255623 Acesso: 02/05/2019, às, $10 \mathrm{~h} 50$. 
Telegraph

https://www.telegraph.co.uk/china-watch/politics/china-russia-india-cooperation/

Acesso: 17/10/2019, às 17h45.

Trans-Caledon Tunnel Authority

https://www.tcta.co.za/ Acesso: 04/06/2019, às 17h43.

Transnet SOC Ltd

https://www.transnet.net/AboutUs/Pages/Overview.aspx Acesso: 04/06/2019, às $17 \mathrm{~h} 47$.

West African Development Bank (BOAD)

https://www.boad.org/en/ Acesso: 15/08/2019, às 20h21.

Sítio Oficial do BRICS para o ano de 2016 (mantido pela Índia)

http://brics2016.gov.in Acesso: 01/08/2019, às 11h27.

Sítio Oficial do BRICS para o ano de 2017 (mantido pela China)

https://www.brics2017.org/English/ Acesso: 01/08/2019, às 11h28.

Sítio Oficial do BRICS para o ano de 2018 (mantido pela África do Sul)

http://www.brics2018.org.za/ Acesso: 01/08/2019, às 11h29.

Sítio Oficial do BRICS para o ano de 2019 (mantido pelo Brasil)

http://brics2019.itamaraty.gov.br/ Acesso: 01/08/2019, às 11h30.

Sítio Oficial do BRICS Business Council (mantido pela Índia): https://www.bricsbusinesscouncil.in/ Acesso: 01/08/2019, às $11 \mathrm{~h} 31$.

U.S. Department of the Treasury

https:/home.treasury.gov/policy-issues/international/multilateral-development-banks

Acesso: 28/10/2019, às 10h44.

Documentos:

BRICS. Acordo Constitutivo sobre o Novo Banco de Desenvolvimento. 2014.

BRICS. Declaração de Fortaleza (VI Cúpula). 2014.

BRICS. Memorando de Entendimento sobre a Criação de um Sítio Web Conjunto do BRICS. 2015.

BRICS. Relatório Anual do NBD de 2016.

BRICS. Relatório Anual do NBD de 2017. Disponível em: https://www.ndb.int/wpcontent/uploads/2018/07/NDB_AR2017.pdf Acesso: 05/06/2019, às 18h30.

BRICS. Relatório Anual do NBD de 2018. 
BRICS. Tratado para o Estabelecimento do Arranjo Contingente de Reservas do BRICS. 2014.

Chairperson's Statement on the BRICS Foreign Ministers Meeting held on 24 March 2014 in The Hague, Netherlands. Disponível em: http://www.dirco.gov.za/docs/2014/brics0324.html Acesso: 17/10/2019, às 18h16.

Convenção sobre Aviação Civil Internacional (1944)

Disponível em: https://www.icao.int/publications/Documents/7300 cons.pdf

Acesso: 30/06/2019, às 10h01.

Declaração de Bogotá (1976)

Disponível em: http://www.jaxa.jp/library/space_law/chapter_2/2-2-1-2_e.html

Acesso: 30/06/2019, às 11h15.

MINISTÉRIO DAS RELAÇÕES EXTERIORES, DIVISÃO DE ATOS INTERNACIONAIS. Atos Internacionais, Prática Diplomática Brasileira, Manual de Procedimentos. Brasília, 2010.

MINISTÉRIO DAS RELAÇÕES EXTERIORES, DIVISÃO DE MECANISMOS INTER-REGIONAIS, DIVISÃO DO AGRUPAMENTO BRICS. Pedido de Acesso à Informação nº 09200000520201878. Brasília, 2018.

Memorandum of Understanding between the New Development Bank and Financial Fund for the Development of the River Plate Basin (FONPLATA)

https://www.ndb.int/wp-content/uploads/2017/05/MOU-with-FONPLATAApril-

2017.pdf Acesso: 13/06/2019, às 21h45.

Memorandum of Understanding Between New Development Bank and Corporación Andina de Fomento on Strategic Cooperation

https:/www.ndb.int/wp-content/uploads/2017/01/MOU-NDB-CAF.pdf

Acesso: 13/06/2019, às 21h46.

Memorandum of Understanding between the Inter-American Development Bank and the Inter-American Investment Corporation and the New Development Bank on General Cooperation

https://www.ndb.int/wp-content/uploads/2018/09/MOU-with-IDB-IDB-Investsigned.pdf Acesso: 13/06/2019, às 21h48.

Memorandum of Understanding Between the New Development Bank and the Eurasian Development Bank on General Cooperation https://www.ndb.int/wp-content/uploads/2017/04/MOU-with-EDBApril-2017.pdf Acesso: 13/06/2019, às 21h50.

Memorandum of Understanding Between the New Development Bank and the European Bank for Reconstruction and Development https://www.ndb.int/wp-content/uploads/2017/04/MOU-with-EBRDApril-2017.pdf Acesso: 13/06/2019, às 21h51. 
Memorandum of Understanding Between New Development Bank and European Investment Bank

https:/www.ndb.int/wp-content/uploads/2017/04/MOU-with-EIBApril-2017.pdf

Acesso: 13/06/2019, às 22h25.

Memorandum of Understanding Between New Development Bank and International Investment Bank on Strategic Cooperation

https:/www.ndb.int/wp-content/uploads/2017/04/MOU-with-IIBArpil-2017.pdf

Acesso: 13/06/2019, às 21h56.

Memorandum of Understanding Between New Development Bank and Asian Infrastructure Investment Bank

https://www.ndb.int/wp-content/uploads/2017/04/MOU-with-AIIBApril-2017.pdf

Acesso: 20/03/2019, às 00h24.

Memorandum of Understanding Between International Bank for Reconstruction and Development International Development Association, International Finance Corporation, Multilateral Investment Guarantee Agency and New Development Bank https://www.ndb.int/wp-content/uploads/2017/01/MOU-NDB-WBG.pdf Acesso: 13/06/2019, às 22h01.

Memorandum of Understanding Between Asian Development Bank and New Development Bank on General Co-operation https://www.ndb.int/wp-content/uploads/2017/01/MOU-ADB-NDB.pdf

Acesso: 13/06/2019, às 22h09.

Memorandum of Understanding on Collaboration on Matters of Common Interest Under the Belt and Road Initiative

https://www.ndb.int/wp-content/uploads/2018/09/MOU-on-BRI-signed.pdf

Acesso: 20/03/2019, às 00h18.

Report of the Legal Subcommittee on its fifty-seventh session, held in Vienna from 9 to 20 April 2018.

https://undocs.org/A/AC.105/1177 Acesso: 30/06/2019, às 10h57.

Report of the Secretary-General on SDG Progress 2019 (Special Edition)

https://sustainabledevelopment.un.org/content/documents/24978Report_of the SG_on SDG_Progress_2019.pdf Acesso: 28/10/2019, às 11h32.

Report of the World Commission on Environment and Development: Our Common Future

https://sustainabledevelopment.un.org/content/documents/5987our-common-future.pdf

Acesso: 22/06/2019, às 16h20.

Resolução A/RES/70/1

https://www.un.org/ga/search/view_doc.asp?symbol=A/RES/70/1\&Lang=E

Acesso: 22/06/2019, às 16h46.

Resolução 688/1991 do Conselho de Segurança das Nações Unidas http://unscr.com/en/resolutions/688 Acesso: 01/05/2019, às 19h34. 
Treaty on Principles Governing the Activities of States in the Exploration and Use of Outer Space, including the Moon and Other Celestial Bodie

http://www.unoosa.org/pdf/gares/ARES_21_2222E.pdf

Acesso: 30/06/2019, às 10h51.

UNDP Strategic Plan, 2018-2021

http://undocs.org/DP/2017/38 Acesso: 19/03/2019 às 22h30. 